U.S. Department of the Interior

U.S. Geological Survey

Prepared in cooperation with the

VIRGINIA DEPARTMENT OF ENVIRONMENTAL QUALITY

under a grant from the

U.S. ENVIRONMENTAL PROTECTION AGENCY

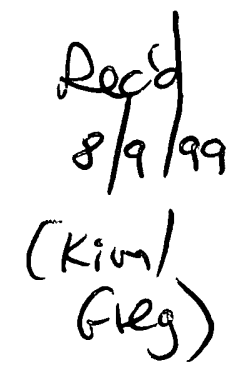

Hydrogeologic Framework and Ground-Water Flow in the Fall Zone of Virginia

Water Resources Investigations Report 99-4093

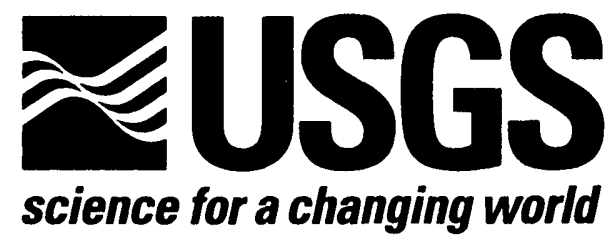


U.S. Department of the Interior

U.S. Geological Survey

\section{Hydrogeologic Framework and Ground-Water Flow in the Fall Zone of Virginia}

By E. Randolph McFarland

Water Resources Investigations Report 99-4093

Prepared in cooperation with the

VIRGINIA DEPARTMENT OF ENVIRONMENTAL QUALITY

under a grant from the

U.S. ENVIRONMENTAL PROTECTION AGENCY

Richmond, Virginia

1999 


\section{U.S. DEPARTMENT OF THE INTERIOR \\ BRUCE BABBITT, Secretary}

\section{U.S. GEOLOGICAL SURVEY}

Charles G. Groat, Director

The use of trade or product names in this report is for identification purposes only and does not constitute endorsement by the U.S. Geological Survey.

For additional information write to:

District Chief, Virginia District

U.S. Geological Survey

1730 East Parham Road

Richmond, VA 23228
Copies of this report can be purchased from:

U.S. Geological Survey

Branch of Information Services

Box 25286, Federal Center

Denver, CO 80225-0286 


\section{CONTENTS}

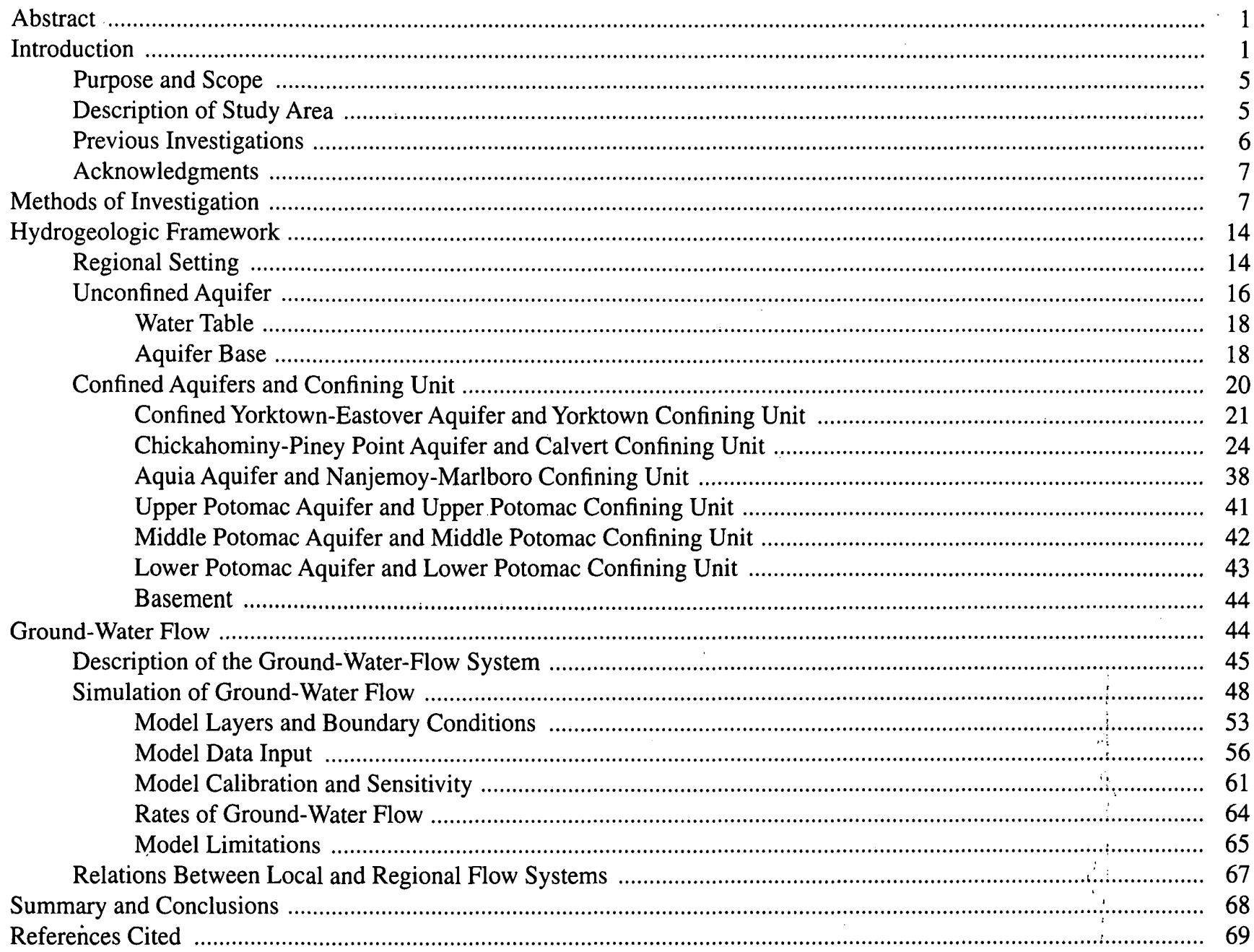

\section{FIGURES}

1. Map showing physiographic provinces in Virginia and major rivers crossing the Fall Zone ...................................

2. Generalized hydrogeologic section and direction of ground-water flow in the Coastal Plain Province of Virginia

3. Map showing locations of wells with electric logs and geologic logs in the Fall Zone of Virginia .......................... 8

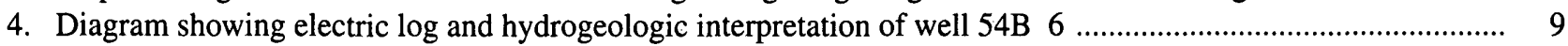

5. Map showing positions of uplands and lowlands and locations of terrain conductivity transects .......................... 11

6. Map showing locations of observation wells .............................................................................................. 15

7. Hydrogeologic sections along terrain conductivity survey transects ................................................................ 22

8-20. Maps showing top elevation of the:

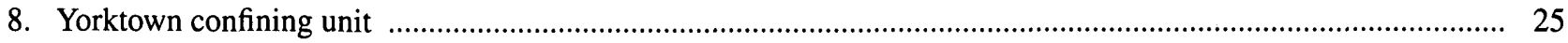

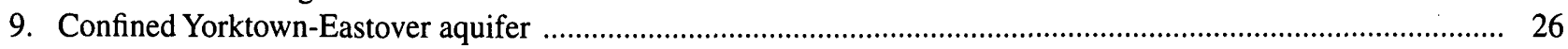

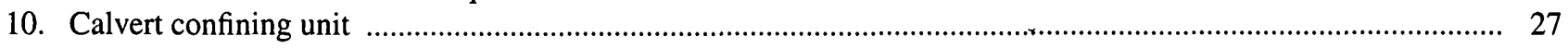

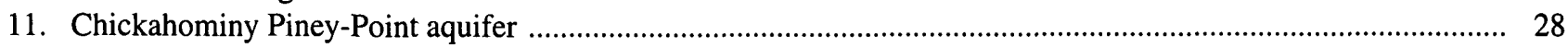

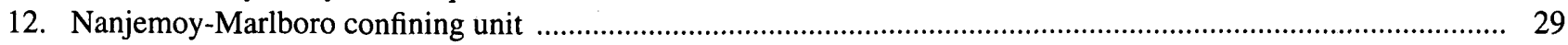




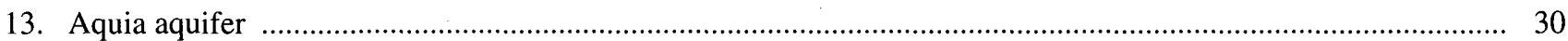

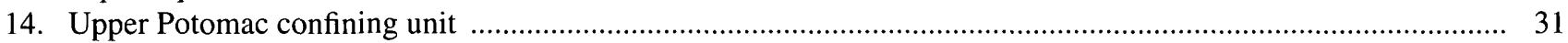

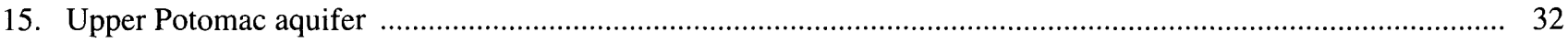

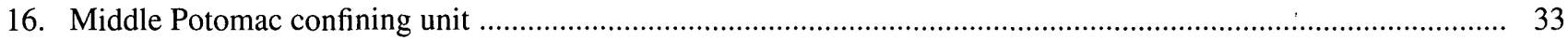

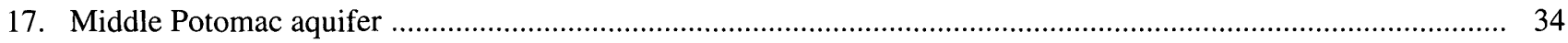

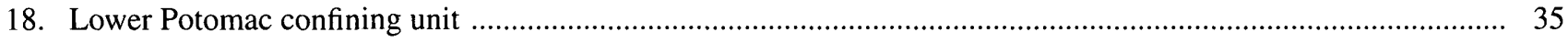

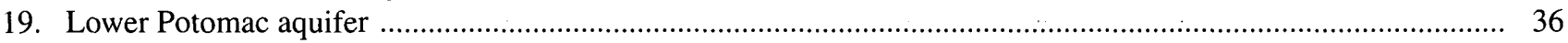

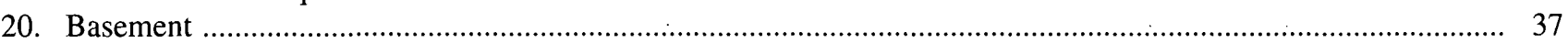

21-22. Diagrams showing summary of relations among geologic formation, and aquifers and confining units in the:

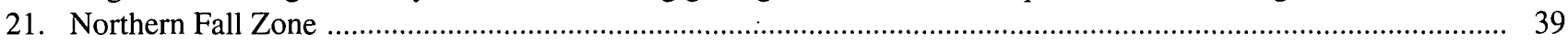

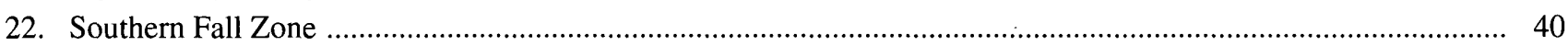

23. Graphs showing instantaneous water-level elevations in observation wells ................................................... 47

24. Map showing water-level elevations in the Chickahominy-Piney Point aquifer and Aquia aquifer ...................... 49

25-27. Maps showing water-level elevations in, and the potentiometric surface of, the

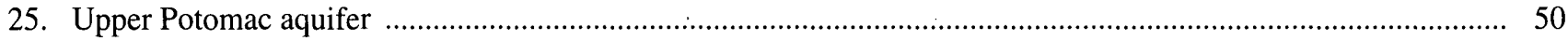

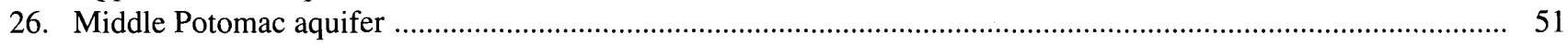

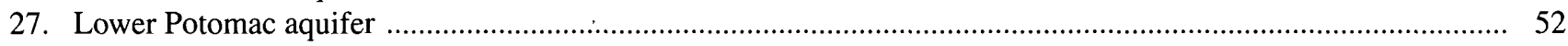

28. Map showing locations of local-scale ground-water-flow model areas, and of pumping tests of the middle Potomac aquifer. 55

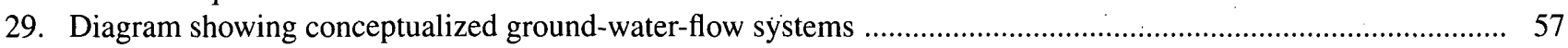

30-31. Maps showing aquifer and confining unit configurations and simulated water-table elevations and heads, for the

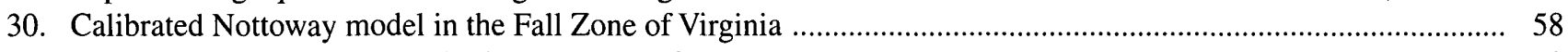

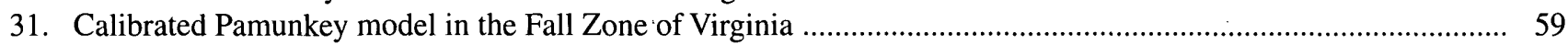

\section{TABLES}

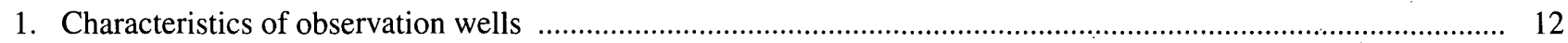

2. Input values and calculated rates of components of flow from local-scale ground-water-flow models …............ 63

\section{APPENDIX}

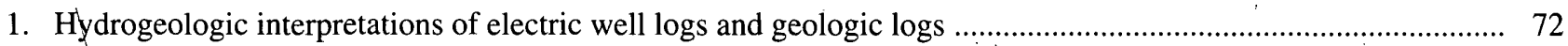

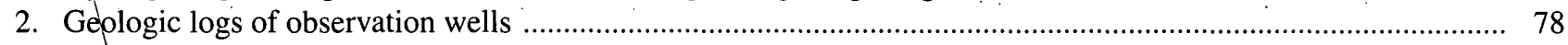




\section{CONVERSION FACTORS AND VERTICAL DATUM}

\begin{tabular}{rcl}
\hline \multicolumn{1}{c}{ Multiply } & By & \multicolumn{1}{c}{ To obtain } \\
\hline inch (in.) & 25.4 & millimeter \\
foot $(\mathrm{ft})$ & 0.3048 & meter \\
mile $(\mathrm{mi})$ & 1.609 & kilometer \\
square mile $\left(\mathrm{mi}^{2}\right)$ & 2.590 & square kilometer \\
foot per mile $(\mathrm{ft} / \mathrm{mi})$ & 5.280 & meter per kilometer \\
inch per year $(\mathrm{in} / \mathrm{yr})$ & 25.4 & millimeter per year \\
foot per day $(\mathrm{ft} / \mathrm{d})$ & .3048 & meter per day \\
foot squared per day $\left(\mathrm{ft}{ }^{2} / \mathrm{d}\right)$ & .09290 & meter squared per day \\
gallon per minute $(\mathrm{gal} / \mathrm{min})$ & .06309 & liter per second \\
million gallons per day $(\mathrm{Mgal} / \mathrm{d})$ & $3,785,000$ & liter per day \\
gallon per day per foot $[(\mathrm{gal} / \mathrm{d}) / \mathrm{ft}]$ & 12.42 & liter per day per meter \\
gallon per minute per foot & .2070 & liter per second per meter \\
{$[(\mathrm{gal} / \mathrm{min}) / \mathrm{ft}]$} & .02832 & cubic meter per second $\left(\mathrm{m}^{3} / \mathrm{s}\right)$ \\
\hline
\end{tabular}

Units of hydraulic properties: Hydraulic conductivity is reported in feet per day ( $\mathrm{ft} / \mathrm{d})$, a mathematical reduction of the unit cubic foot per day per square foot $\left[\left(\mathrm{ft}^{3} / \mathrm{d}\right) / \mathrm{ft}^{2}\right]$. Transmissivity is reported in feet squared per day $\left(\mathrm{ft}^{2} / \mathrm{d}\right)$, a mathematical reduction of the unit cubic feet per day per square foot times feet of aquifer thickness $\left(\left[\left(\mathrm{ft}^{3} / \mathrm{d}\right) / \mathrm{ft}^{2}\right] \mathrm{ft}\right]$.

Vertical datum: In this report "sea level" refers to the National Geodetic Vertical datum of 1929 (NGVD of 1929)--a geodetic datum derived from a general adjustment of the first-order level nets of both the United States and Canada, formerly called Sea Level Datum of 1929. 



\title{
Hydrogeologic Framework and Ground-Water Flow in the Fall Zone of Virginia
}

\author{
By E. Randolph McFarland
}

\section{Abstract}

Within the Fall Zone at the western margin of the Coastal Plain in Virginia, the unconfined aquifer is composed of Tertiary- to Quaternary-age surficial deposits of generally coarse-grained sediments that are incised to depths as great as $50 \mathrm{ft}$ into underlying confined aquifers and intervening confining units. This incision results in subcrop areas of some confined aquifers along parts of the Potomac, Rappahannock, Mattaponi, Pamunkey, Chickahominy, James, Nottoway, and Meherrin Rivers and their tributaries. The Yorktown-Eastover, Chickahominy-Piney Point, and Aquia confined aquifers, and the Yorktown, Calvert, and Nanjemoy-Marlboro confining units, generally consist of Tertiary-age marine deposits of poorly sorted, glauconitic sand with varying amounts of shell, silt, and clay that extend to elevations as low as $-300 \mathrm{ft}$. The aquifers are distinguished from the confining units primarily in being coarser grained and having a greater shell content. The upper Potomac, middle Potomac, and lower Potomac confined aquifers, and the upper Potomac, middle Potomac, and lower Potomac confining units, generally consist of Cretaceousage fluvial and deltaic deposits of medium-tocoarse grained quartz sand with varying amounts of gravel, silt, and clay that extend to elevations as low as $-1500 \mathrm{ft}$. The aquifers include zones of relatively concentrated but discontinuous sandrich beds, and the confining units include zones of relatively concentrated but discontinuous clay-rich beds.

Hydrologic relations between the unconfined and confined ground-water-flow systems within the Fall Zone are similar to those in other parts of the Virginia Coastal Plain. Ground water throughout the Coastal Plain is recharged at the water table. Volumetric rates calculated by local-scale ground-water-flow models of the Fall Zone indicate that, of an estimated $10 \mathrm{in} / \mathrm{yr}$ of recharge at the water table, greater than $9 \mathrm{in} / \mathrm{yr}$ discharges locally to rivers and streams. Less than $1 \mathrm{in} / \mathrm{yr}$ leaks downward to confined aquifers to provide recharge to the regional flow system. Flow through confined aquifers is in the regionally downgradient direction toward the east but also is locally directed toward discharge along major rivers, where confined aquifers and confining units are incised by the rivers and overlain by floodplain and terrace deposits. Approximately $2 \mathrm{in} / \mathrm{yr}$ is exchanged locally between the unconfined and confined parts of the flow system where confined aquifer subcrop areas are present in the Fall Zone. Previous studies indicate that areas and rates of downward leakage and recharge to confined aquifers have increased throughout the Virginia Coastal Plain as a result of large withdrawals at locations east of the Fall Zone. Although the Fall Zone was possibly a significant source of regional recharge prior to the large withdrawals, greater rates of regional recharge potentially have resulted from large drawdowns near major pumping centers located farther east.

\section{INTRODUCTION}

Aquifers in the Coastal Plain Physiographic Province (Coastal Plain) in Virginia (fig. 1) are heavily used sources of water supply that account for approximately 45 percent of total ground-water withdrawals reported within the State (McFarland and Focazio, 1993). As a result of locally concentrated pumping, ground-water levels in the Coastal Plain aquifers have declined by as much as $200 \mathrm{ft}$, primarily near large withdrawal centers in the southeastern part 


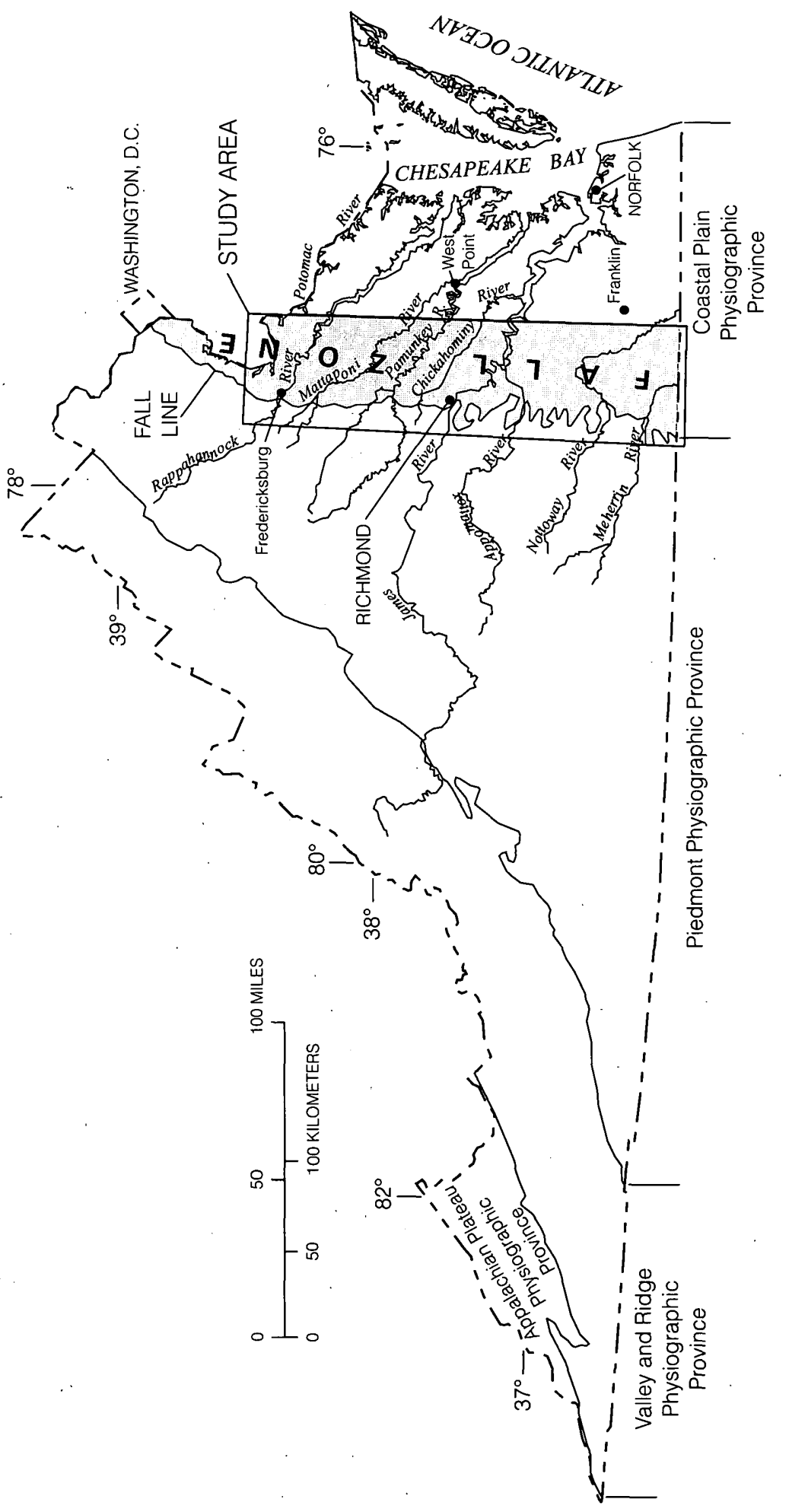

O) 
of the State. Further declines could result from increasing withdrawals and could limit continued use of the resource.

The U.S. Geological Survey (USGS), in cooperation with the Virginia Department of Environmental Quality (DEQ), has analyzed changes in ground-water levels and flow caused by withdrawal from aquifers in the Coastal Plain of Virginia. A digital ground-water-flow model (Virginia Coastal Plain model) was constructed to study regional-scale patterns of ground-water flow (Harsh and Laczniak, 1990). The model simulates widespread and long-term trends in water-level decline that are caused by large withdrawals, primarily from deep and thick confined aquifers. In order to protect the future viability of water supplies, DEQ bases its ground-water management decisions for the Coastal Plain aquifers partly on results of model simulations of declines caused by continued and proposed withdrawals. The certainty of the simulation results, however, is limited in part by incomplete knowledge of the hydrologic conditions and processes that control ground-water flow along the western margin of the Coastal Plain, termed the Fall Zone (fig. 1). Because construction of the Virginia Coastal Plain model focused on thick, deep aquifers that underlie the southeastern part of the Coastal Plain in Virginia, more generalized information was incorporated to represent the Fall Zone.

The boundary between the Coastal Plain and the Piedmont Physiographic Province (Piedmont) to the west is referred to in this report as the Fall Line (fig. 1). Numerous falls and rapids are present along streams near the Fall Line, where their gradients increase as they flow generally eastward from resistant bedrock onto more easily eroded sediments. The area extending from the Fall Line eastward as far as 77 degrees longitude, encompassing the westernmost part of the Coastal Plain and the margin between the Coastal Plain and the Piedmont, is referred to here as the Fall Zone (fig. 1). It represents a transition zone between the Fall Line and areas farther east within the Coastal Plain.

Although previous studies have not provided detailed information, hydrogeologic conditions in the Fall Zone have been recognized as distinct from those in other parts of the Coastal Plain. Some aquifers pinch out westward toward the Fall Line (fig. 2), and the vertical sequence of aquifers beneath the Fall Zone differs from that in other parts of the Coastal Plain. Aquifers within the Fall Zone also are relatively thin and shallow, and subcrop areas are present along major rivers. Flow interactions between the aquifers and rivers potentially are pronounced because of direct hydraulic connections. In addition, the Fall Zone has been theorized to be a major upgradient recharge area for the entire Virginia Coastal Plain aquifer system (Harsh and Laczniak, 1990). Downward leakage to confined aquifers in the Fall Zone potentially provides much of the water to parts of the aquifers farther east. Details of this "regional recharge" are lacking, however, because the distribution and properties of the confined aquifers and their interactions with rivers are not well understood.

As part of a long-term effort to better understand hydrogeologic conditions throughout the Virginia Coastal Plain and to improve the effectiveness of the Virginia Coastal Plain model for supporting groundwater management decisions, the USGS, in cooperation with DEQ, conducted a study of hydrogeologic conditions within the Fall Zone in Virginia during 1995-98. The study was designed to (1) improve the description of regional aquifers and confining units within the Fall Zone, particularly their geometric configurations, lithologic compositions, and geological relations, collectively referred to in this report as the hydrogeologic framework, and (2) describe the ground-water flow system within the Fall Zone, particularly with regard to flow interactions between aquifers and rivers, and its relation to regional flow in the Coastal Plain aquifer system of Virginia.

Because the hydrogeology of the Fall Zone is complex, the study was undertaken in two phases. The initial phase, undertaken during 1995-96, consisted in part of detailed field-based investigation and flowmodel analysis of part of the Fall Zone near Richmond, Va. (fig. 1), to identify and describe local-scale hydrogeologic conditions associated with the James River, the largest river to cross the Fall Zone within Virginia. Results of this investigation were published in McFarland (1997). Also, the hydrogeologic framework was delineated along the southern part of the Fall Zone extending from Richmond southward to the State line.

The scope of the study was expanded in the second phase during 1997-98 to incorporate most of the Fall Zone in Virginia, extending from Fredericksburg, Va. (fig. 1), southward to the State line. The hydrogeologic framework of the Fall Zone was delineated between Richmond and Fredericksburg and was integrated with the earlier delineated framework south of Richmond. Limited field investigation was undertaken to augment preexisting framework 


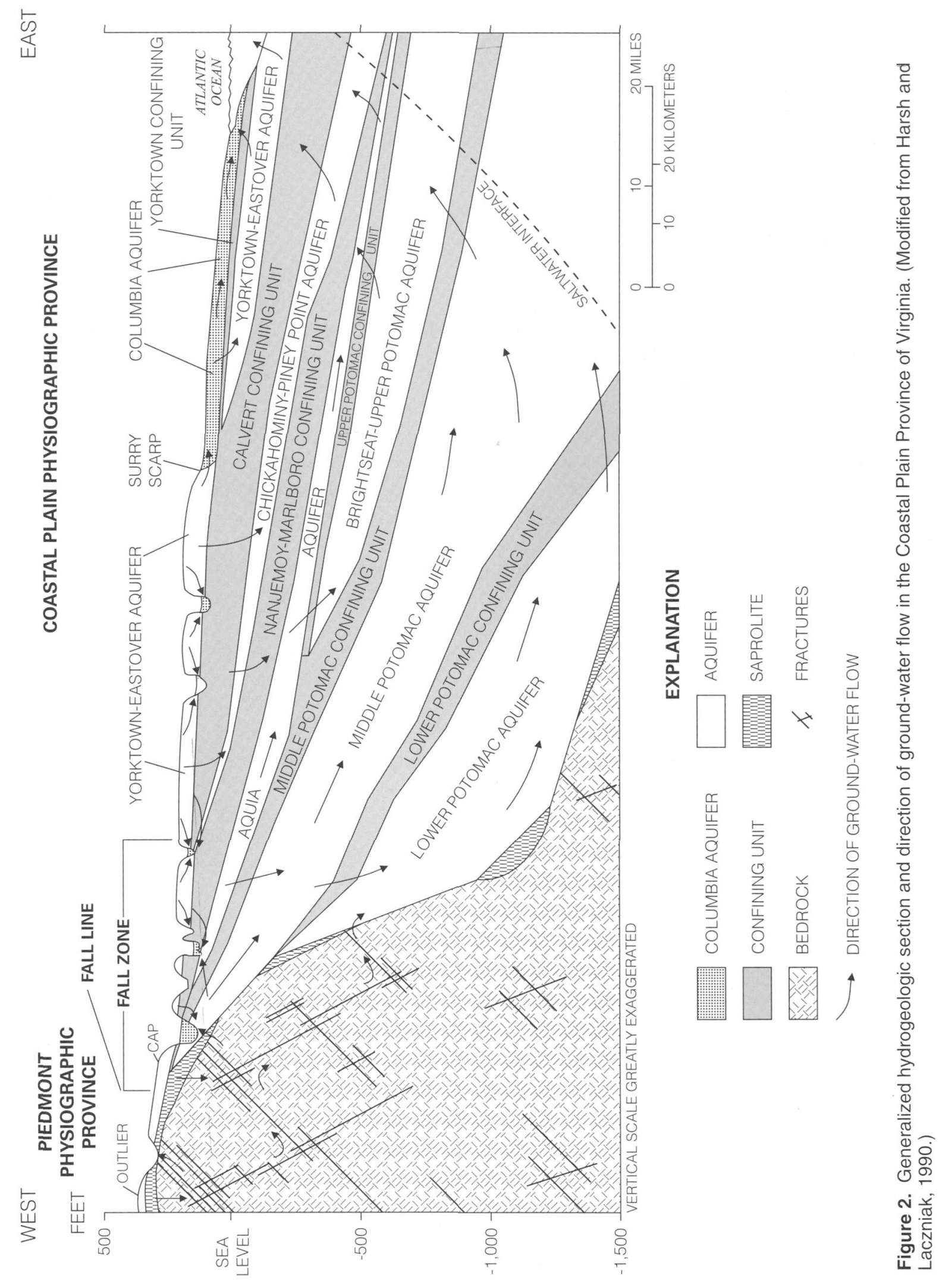


information, and two additional local-scale flow models were constructed to compare to model analyses from the initial phase. The northernmost part of the Fall Zone, between Fredericksburg and Washington D.C., was excluded from the study because of its relative isolation from the rest of the Virginia Coastal Plain (fig. 1). It likely has little direct hydraulic interaction with ground-water flow in the Virginia part of the Coastal Plain aquifer system.

\section{Purpose and Scope}

This report presents the results of an investigation of ground-water conditions within the Fall Zone in Virginia during 1995-98. The geometric configurations, lithologic compositions, and geological relations of regional aquifers and confining units are described.

Distributions of water levels within each aquifer are presented and are used to infer hydraulic gradients and ground-water-flow directions. Simulations by local-scale numerical models of ground-water flow in two contrasting settings within the Fall Zone are presented. Simulated rates of recharge at the water table, discharge to surface water, and recharge to the regional flow system are compared between the models. Local-scale flow within the Fall Zone is related to regional-scale flow throughout the Virginia Coastal Plain.

\section{Description of Study Area}

The study area includes the Fall Zone in Virginia from Fredericksburg southward to the State line and from near the Fall Line east to 77 degrees longitude (fig. 1). The climate is humid temperate, and annual precipitation is approximately 40 in. (National Weather Service, 1996). West of the Fall Line lies the Piedmont (fig. 1), which is characterized by rolling terrain underlain predominantly by igneous and metamorphic rocks of late Proterozoic and early Paleozoic age, residual soils that range from nearly 0 to $100 \mathrm{ft}$ thick, and fault-bounded structural basins that contain sedimentary and igneous rocks of Mesozoic age. Shallow alluvial deposits are localized in stream valleys. East of the Fall Line lies the Coastal Plain, which is characterized by rolling terrain and deeply incised stream valleys in the northwestern part, and gently rolling-to-level terrain, broad stream valleys, and extensive wetlands in the eastern and southern parts. The Coastal Plain is underlain by a seawardthickening wedge of regionally extensive, eastward dipping strata of unconsolidated to partly consolidated sediments of Cretaceous, Tertiary, and Quaternary age that unconformably overlie Piedmont rocks (fig. 2). The configuration of the Fall Line is intricate because streams have eroded through Coastal Plain sediments to expose Piedmont bedrock in their valley floors; interstream divides are capped by uneroded sediments overlying the bedrock (Mixon and others, 1989).

Hydrogeologic conditions in the Piedmont are distinct from the Coastal Plain. Ground water in the Piedmont is present largely in fractures in bedrock and in pores in weathered residuum developed on the bedrock. In the Coastal Plain, ground water is present in pores in between the sediment grains; thick sequences of porous and permeable strata form regional aquifers (fig. 2), and less permeable strata form confining units between the aquifers.

Several major rivers, including the Rappahannock, Mattaponi, Pamunkey, Chickahominy, James, Appomattox, Nottoway, and Meherrin, cross the Fall Zone in Virginia (fig. 1). These rivers receive flow from dense and extensive networks of tributaries that span their entire drainage basins. The Potomac River also crosses the Fall Zone; between Fredericksburg and Washington, D.C., however, its course diverges from the generally eastward drainage and thereby hydraulically isolates the northernmost part of the Fall Zone in Virginia from the rest of the Coastal Plain in Virginia.

Topography in the Fall Zone is dominated by the valleys of the major rivers, which are incised into Coastal Plain sediments. Lowlands consisting of terraces, floodplains, and wetlands are within river valleys and are flanked by broad uplands along basin boundaries. The uplands and lowlands are bounded by relict erosional scarps associated with the rivers (Johnson and Ramsey, 1987); these scarps are obscured in places by the present-day tributary drainage pattern. Land-surface elevation ranges from near sea level along the downstream parts of the rivers to higher than $200 \mathrm{ft}$ in the uplands.

Hydrogeologic conditions in the Fall Zone are distinct from those in other parts of the Coastal Plain. Although ten aquifers have been delineated within the Virginia Coastal Plain, none of the aquifers span the entire area (McFarland, 1997). A complex history of 
sediment deposition throughout the Coastal Plain has produced numerous lateral variations in sediment composition. Consequently, the positions of aquifer margins vary widely among the aquifers, and the areal distribution of the aquifers has a complex overlapping configuration. In particular, some aquifers pinch out westward toward the Fall Line, and the vertical sequence of aquifers beneath the Fall Zone differs from that in other parts of the Coastal Plain (fig. 2). In addition, aquifers within the Fall Zone are relatively thin and shallow and subcrop areas are present along major rivers. Flow interactions between some aquifers and rivers possibly are more pronounced in the Fall Zone than elsewhere in the Coastal Plain because of direct hydraulic connections at the land surface.

\section{Previous Investigations}

One of the earliest comprehensive efforts to document physiographic and geologic conditions in the Coastal Plain in Virginia was by Clark and Miller (1912). Shortly thereafter, Sanford (1913) completed a comprehensive report on the ground-water resources of the Virginia Coastal Plain. D.J. Cederstrom produced several reports, including one (Cederstrom, 1945) that is a major milestone in the hydrogeology of the Coastal Plain. Although recent investigations in the Coastal Plain in Virginia have resulted in many minor revisions, the fundamental aspects of the earlier work have been retained. As a typical example, a comprehensive synthesis of geological studies was incorporated into a revised and highly detailed geologic map of the Virginia Coastal Plain by Mixon and others (1989).

The most comprehensive analysis of the hydrogeology of the Coastal Plain in Virginia to date was produced by the USGS Regional Aquifer System Analysis (RASA) Program. The hydrogeologic framework of the entire Coastal Plain in Virginia was defined by Meng and Harsh (1988), who incorporated the work of many previous studies as well as a large volume of newly collected data. A digital groundwater-flow model (the Virginia Coastal Plain model) was constructed on the basis of the RASA-defined framework to study regional-scale patterns of groundwater flow (Harsh and Laczniak, 1990). The hydrogeologic framework and ground-water-flow model have subsequently been modified on the basis of results of more detailed studies in southeastern Virginia (Hamilton and Larson, 1988) and in the York-James
Peninsula (Laczniak and Meng, 1988). The current form of the RASA framework and Virginia Coastal Plain model (McFarland, 1998) provides an interpretive baseline on which many subsequent ground-water investigations are based (including the study presented in this report).

The Fall Zone historically has been viewed as a major upgradient regional recharge area for the entire Coastal Plain aquifer system in Virginia. Previous studies within the Virginia Coastal Plain (Harsh and Laczniak, 1990; Hamilton and Larson, 1988; Laczniak and Meng, 1988) assert that the principal areas of downward leakage into the confined aquifers include the Fall Zone, as well as major surface-drainage divides elsewhere in the Coastal Plain. Upward leakage and ground-water discharge throughout the Coastal Plain occurs primarily beneath major rivers and along coastal areas: incision of the rivers and associated floodplain and terrace deposits into the aquifers and confining units enhances the hydraulic connections that promote ground-water discharge at the land surface.

Concern about regional-scale hydraulic stresses imposed on the aquifer system have prompted various investigations of the effects of the stresses throughout the Virginia Coastal Plain, including the Fall Zone. Large cones of depression associated with water-level declines at major withdrawal centers, primarily located east of the Fall Zone at West Point, Franklin, and Norfolk (fig. 1), have redirected the flow in some aquifers during the past several decades toward the withdrawal centers (Harsh and Laczniak, 1990; Hamilton and Larson, 1988; Laczniak and Meng, 1988). Regional hydraulic gradients (Hammond and others, 1994) indicate that much of the regional recharge from within the Fall Zone probably is intercepted by the large withdrawal centers.

In addition to the above cited investigations, several geological investigations were useful to characterize the hydrogeologic framework of the Fall Zone. Among these, Ward and Blackwelder (1980) and Ward (1985) describe surface exposures of Tertiary-age geologic formations and discuss their regional spatial distributions and depositional histories. Johnson and Ramsey (1987) describe Quaternary-age formations and relate their spatial distributions to the geomorphic evolution of terraces and erosional scarps that characterize the landscape. Mixon and others (1988) identify complex structural features within the northern Fall Zone in Virginia. Dischinger (1987) describes 
stratigraphic and structural relations near the James

River. Powars and others (1988) describe stratigraphic relations in southeastern Virginia.

\section{Acknowledgments}

This study was supported by the Virginia Department of Environmental Quality under a grant from the U.S. Environmental Protection Agency. The author wishes to thank Terry Wagner, Mary Ann Massie, and T. Scott Bruce, of the Virginia Department of Environmental Quality, for program and planning support, operational assistance, and for providing water-supply well data and diverse other information. Permission for access to drilling and observation-well measurement sites was generously provided by John Cramer, Robert Pickett, and Ronald Reekes of the Virginia Department of Transportation, Brad Ashley of the Hanover County Department of Parks and Recreation, and Doug Terry of the Sparta Fire Department. The Virginia Division of Mineral Resources provided numerous lithologic descriptions of drill cuttings. Thanks are also extended to the many drillers and owners of water-supply wells who have provided well log, construction, and water-level data. In particular, Syndor Hydrodynamics, Inc., provided the majority of geophysical well logs on which interpretations of the hydrogeologic framework were based.

\section{METHODS OF INVESTIGATION}

The geometric configurations of regional aquifers and confining units were delineated on the basis of interpretations made from data obtained for 138 wells (app. 1) located in the Fall Zone in Virginia (fig. 3). Geophysical borehole logs and other data were obtained from records of 128 wells on file at DEQ, the Virginia Division of Mineral Resources (VDMR), and the USGS Virginia District office in Richmond, Va. The records were compiled as part of ongoing programs of these agencies and also from earlier studies, including the initial phase of this study (McFarland, 1997). Lithologic descriptions of subsurface materials, obtained for a majority of the geophysically logged wells and from approximately several dozen additional unlogged wells, also were examined to aid in geophysical log interpretation.
Methods of geophysical borehole-log interpretation are presented by Keys (1990). Application of log interpretation to delineate the hydrogeologic framework of the Coastal Plain in Virginia is discussed by Meng and Harsh (1988) and is not reiterated in detail here. Interpretations made for this study were based principally on combined logs of spontaneous potential and electrical resistivity, commonly referred to as electric logs (fig. 4). Vertical variations of spontaneous potential and electrical resistivity measured in the borehole are examined to identify intervals of contrasting permeability: intervals indicating relatively high permeability are inferred to represent aquifers and those indicating relatively low permeability are inferred to represent confining units.

Meaningful interpretation of a given electric log requires integration of information beyond that indicated solely on the log. Vertical variations in spontaneous potential and electrical resistivity as indicated on the log depend on measurement technique and borehole conditions, and interpretation of the positions of aquifers and confining units is largely subjective. Accordingly, additional information was incorporated where possible to corroborate electric log interpretation. The sedimentary compositions, regional extents, and stratigraphic positions of geologic formations were inferred from geologic maps and other published information. In addition, lithologic descriptions of subsurface materials included among the existing records, both from the logged wells and from nearby unlogged wells, were used to indicate the compositions of different intervals identified on the logs and to establish stratigraphic relations between the aquifers and confining units and their corresponding geologic formations. Separate borehole logs of natural gamma radiation obtained for a small number of the wells also were used where available to indicate lithologic composition. The lithologic descriptions generally were made from drill cuttings, which are mixed among different depth intervals by varying degrees during drilling, or from drillers' notes, which often lack accuracy. Hence, the lithologic descriptions alone generally are not adequate to infer aquifer and confining unit positions and were considered solely to aid in electric log interpretation. Full documentation of all information in the existing records is beyond the scope of this report, but the records are on file at the Richmond, Va., office of the USGS. 

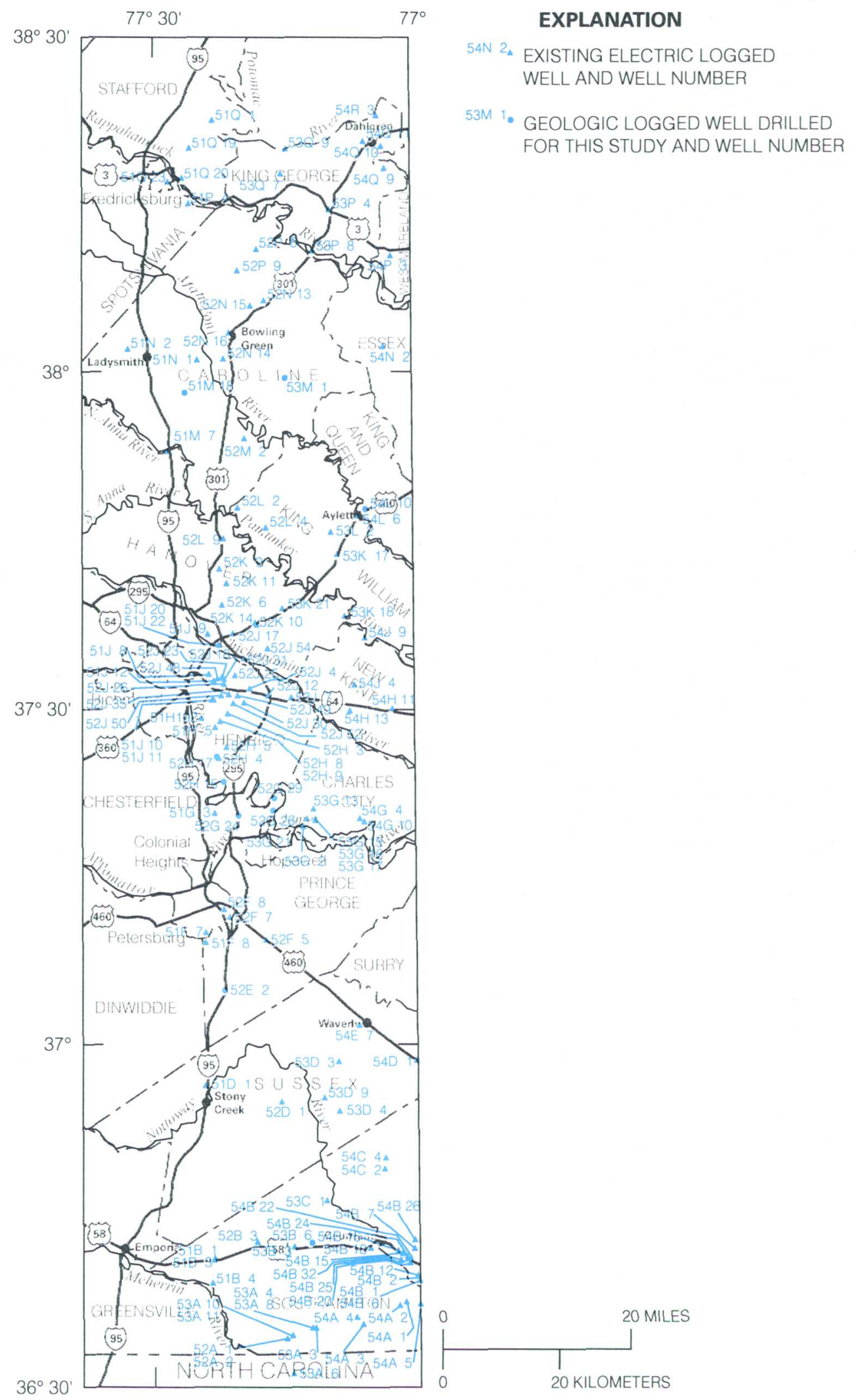

20 MILES

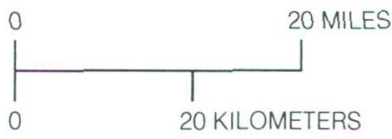

Figure 3. Locations of wells with electric logs and geologic logs in the Fall Zone of Virginia. 
SEA LEVEL

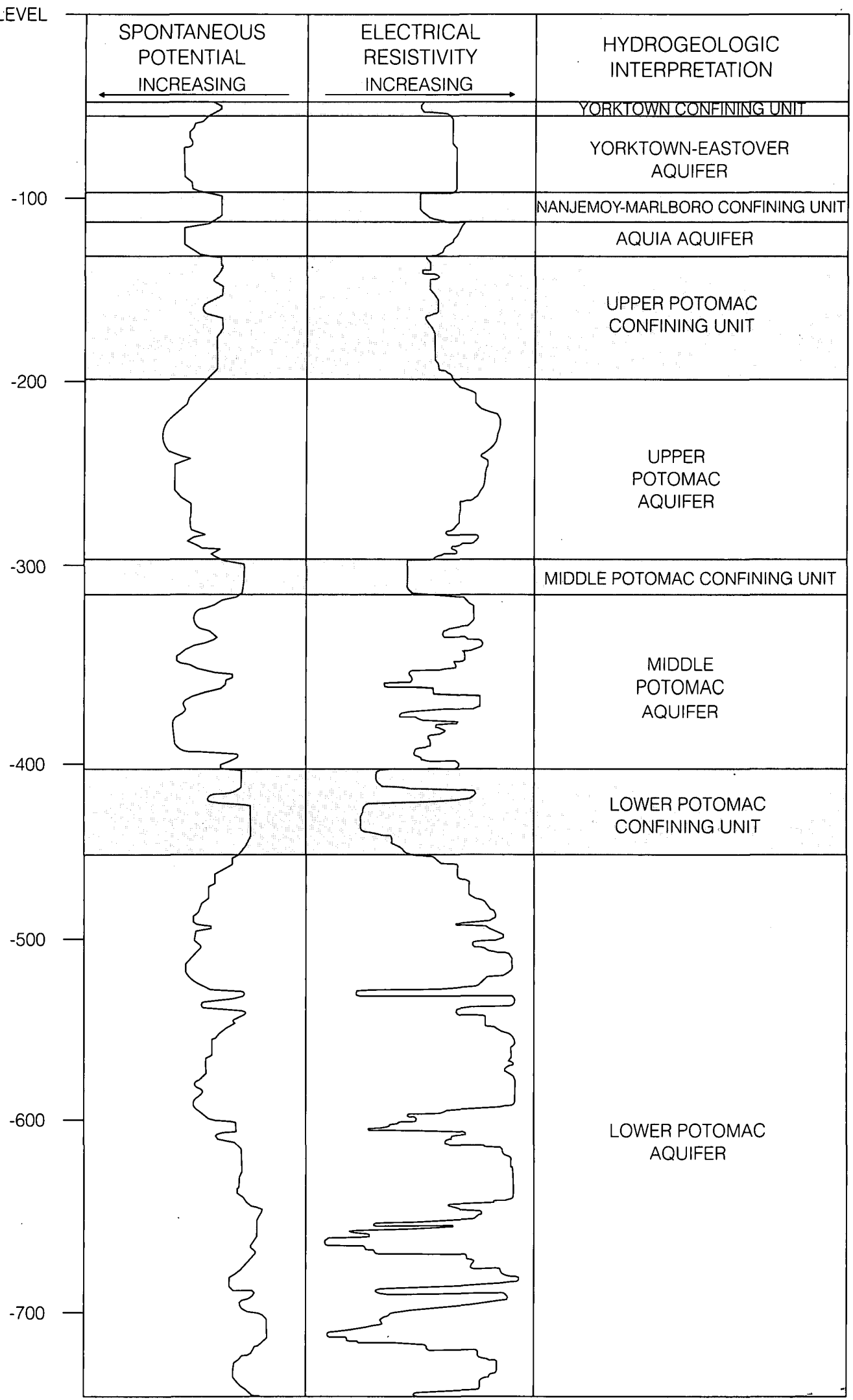

Figure 4. Electric log and hydrogeologic interpretation of well 54B 6 in the Fall Zone of Virginia. Log generated on May 5, 1969, by O.J. Cosner and G.A. Brown of the U.S. Geological Survey. 
In addition to the electric logs, geologic logs of 10 wells drilled as part of this study were also used to delineate the hydrogeologic framework (app. 1). Five of the wells were drilled near the James River during the initial phase of the study and are documented in McFarland (1997). Five additional wells were drilled as part of the second phase of the study during April and May 1997 at widely spaced locations chosen to address gaps in the existing data. During both study phases, subsurface materials collected by augering, and by split-spoon sampling at 5-ft intervals, were examined to construct a geologic log of each auger hole (app. 2); the geologic logs were interpreted along with the existing electric logs to infer aquifer and confining unit positions at the drilling locations (app. 1).

In order to augment the hydrogeologic framework, terrain-conductivity surveys were conducted in the Fall Zone in Virginia during November and December of 1997 to delineate local deposits of lowland floodplains and terraces that are incised into underlying strata. The lowland deposits together with adjacent upland deposits constitute the unconfined surficial aquifer. Because the depositional history of these deposits is complex, the contact surface between them and underlying sediments has a complex shape and cannot be delineated accurately by interpolating among well-log locations, as is done for the confined aquifers and confining units.

Methods of terrain-conductivity surveying and their application to delineate lithologic changes are described by Haeni (1986). Terrain-conductivity measurements are used to infer thicknesses of vertically discrete layers of contrasting electrical conductivity beneath the land surface. In this study, the electrical conductivity of the sand and gravel composing the surficial deposits is theorized to be roughly one to two orders of magnitude less than that of the underlying fine-grained marine sediments, which results in a marked contrast in electrical conductivity between the layers.

Terrain conductivity was measured at locations along lines, referred to as transects, oriented approximately perpendicular to the axes of major river valleys in the Fall Zone (fig. 5). Locations of the transects were chosen to represent contrasting settings within different parts of the Fall Zone in areas where existing information was most scarce. The transects vary in length from approximately $2 \mathrm{mi}$ to $8 \mathrm{mi}$, consist of from 5 to 9 measurement locations, and traverse from uplands across lowland floodplains and terraces.

The electrical conductivity of subsurface materials was measured using a Geonics model EM-34 terrain conductivity meter. A magnetic field, the strength of which is proportional to the electrical conductivity of the materials through which it passes (Interpex Limited, 1989), is induced through the subsurface. In order to delineate distinct layers, different instrument configurations are used to vary the depth below the land surface to which the magnetic field is induced (and hence the volume of subsurface materials through which it passes), resulting in up to six measurements at each location that represent penetration depths from 7.5 to 60 meters.

In order to determine the distributions of hydraulic head in the aquifers, ground-water level and other data were examined from 45 observation wells (table 1) located throughout the Fall Zone in Virginia (fig. 6). More than half of wells (25) are open to the middle Potomac aquifer. An additional 10 wells are open to the Aquia aquifer, 5 to the lower Potomac aquifer, and 4 to the upper Potomac aquifer. Only 1 well is open to the Chickahominy-Piney Point aquifer.

Water levels were measured, as depths below land surface, to within $0.01 \mathrm{ft}$. In order to determine head distributions, water-level elevations were calculated (table 1) by subtracting the water-level depth at each well from the land-surface elevation. Landsurface elevations, however, vary widely among well locations and were approximately estimated from topographic maps only to within $5 \mathrm{ft}$ (based on elevation-contour intervals of $10 \mathrm{ft}$ ). Therefore, calculated water-level elevations also are accurate only to within $5 \mathrm{ft}$. 


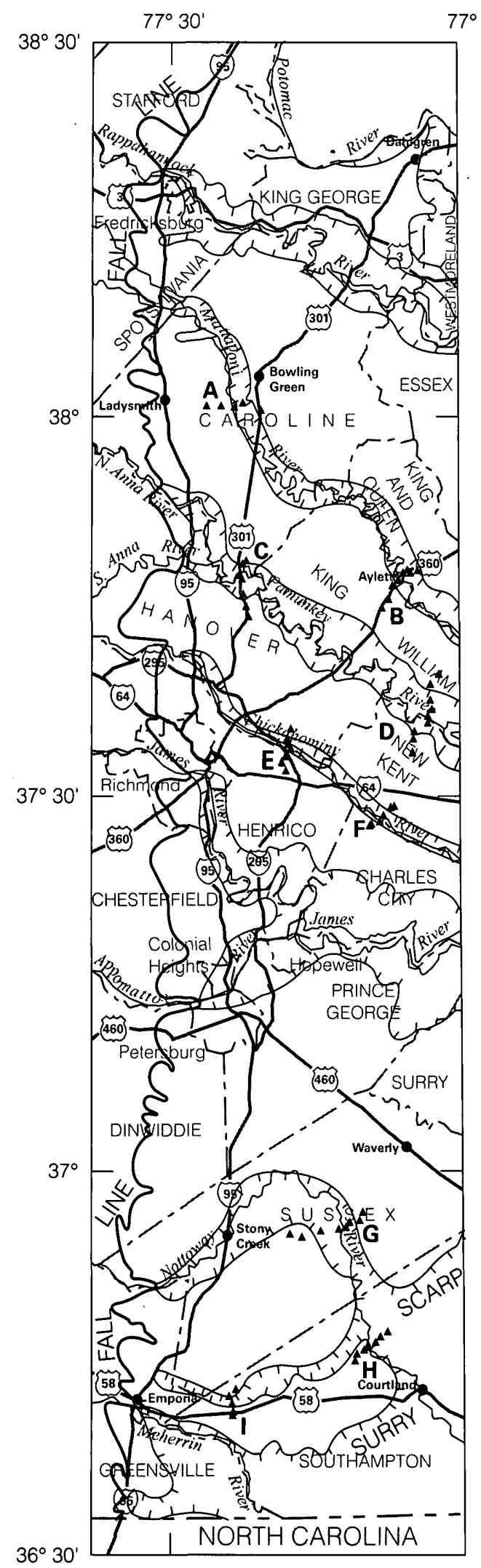

\section{EXPLANATION}

ПTा EROSIONAL SCARP-Hachures toward lowland and away from upland

A.ム TERRAIN CONDUCTIVITY

TRANSECT_Symbols

indicate measurement locations

Figure 5. Positions of uplands and lowlands and locations of terrain conductivity transects in the Fall Zone of Virginia. Erosional scarps inferred from surface topography. 
Table 1. Characteristics of observation wells in the Fall Zone, Virginia

[Datum is sea level, accurate to within 5 feet; latitude and longitude in degrees, minutes, and seconds; SN, statewide water-level observation network (White and Powell, 1997); P1, initial phase of this study (McFarland, 1997); P2, second phase of this study; --, no data]

\begin{tabular}{|c|c|c|c|c|c|c|c|c|}
\hline \multirow{2}{*}{\multicolumn{2}{|c|}{$\begin{array}{c}\text { Well } \\
\text { number }\end{array}$}} & \multirow[b]{2}{*}{ Latitude } & \multirow[b]{2}{*}{ Longitude } & \multirow[b]{2}{*}{ Aquifer } & \multicolumn{4}{|c|}{ Approximate elevation, in feet } \\
\hline & & & & & $\begin{array}{l}\text { Water } \\
\text { level }\end{array}$ & $\begin{array}{l}\text { Top of open } \\
\text { interval }\end{array}$ & $\begin{array}{c}\text { Bottom of } \\
\text { open } \\
\text { interval }\end{array}$ & $\begin{array}{l}\text { Source of } \\
\text { information }\end{array}$ \\
\hline $51 \mathrm{~B}$ & 3 & 364109 & 772307 & middle Potomac & 63 & -39 & -49 & $\mathrm{SN}$ \\
\hline $51 \mathrm{M}$ & 18 & 375811 & 772549 & Aquia & 100 & 62 & 57 & P2 \\
\hline $52 \mathrm{~A}$ & 1 & 363410 & 771508 & middle Potomac & -9 & -160 & -173 & SN \\
\hline $52 \mathrm{~B}$ & 8 & 363916 & 772010 & middle Potomac & 50 & -165 & -175 & $\mathrm{SN}$ \\
\hline $52 \mathrm{~B}$ & 9 & 363916 & 772010 & middle Potomac & 49 & -178 & -188 & SN \\
\hline $52 \mathrm{~B}$ & 10 & 363916 & 772010 & middle Potomac & 46 & -98 & -108 & SN \\
\hline $52 \mathrm{~B}$ & 11 & 363916 & 772010 & middle Potomac & 49 & -40 & -50 & $\mathrm{SN}$ \\
\hline $52 \mathrm{~B}$ & 12 & 363916 & 772010 & upper Potomac & 50 & 0 & -10 & $\mathrm{SN}$ \\
\hline $52 \mathrm{E}$ & 2 & 370501 & 772144 & middle Potomac & 121 & 76 & 71 & $\mathrm{P} 2$ \\
\hline $52 \mathrm{~F}$ & 1 & 371315 & 771719 & middle Potomac & 56 & -38 & -48 & SN \\
\hline $52 \mathrm{G}$ & 15 & 371727 & 771604 & middle Potomac & 10 & -39 & -49 & $\mathrm{SN}$ \\
\hline $52 \mathrm{G}$ & 16 & 1371727 & 771604 & middle Potomac & 9 & -109 & -119 & SN \\
\hline $52 \mathrm{G}$ & 24 & 372031 & 772000 & middle Potomac & 57 & 10 & 5 & P1 \\
\hline $52 \mathrm{G}$ & 26 & 372056 & 771607 & middle Potomac & 1 & -26 & -31 & P1 \\
\hline $52 \mathrm{G}$ & 29 & 372202 & 771602 & middle Potomac & 1 & -80 & -85 & $\mathrm{P} 1$ \\
\hline $52 \mathrm{H}$ & 15 & 372332 & 772142 & middle Potomac & 37 & 11 & 6 & P1 \\
\hline $52 \mathrm{H}$ & 17 & 372538 & 772215 & Aquia & 85 & 61 & 56 & $\mathrm{P} 1$ \\
\hline $52 \mathrm{~J}$ & 1 & 373301 & 771940 & middle Potomac & -34 & -40 & -134 & $\mathrm{SN}$ \\
\hline $52 \mathrm{~J}$ & 10 & 373507 & 771712 & middle Potomac & -21 & -83 & -98 & $\mathrm{SN}$ \\
\hline $52 \mathrm{~J}$ & 34 & 373125 & 771850 & middle Potomac & -32 & -60 & -103 & SN \\
\hline $52 \mathrm{~J}$ & 35 & 373117 & 772102 & middle Potomac & -46 & -60 & -100 & $\mathrm{SN}$ \\
\hline $52 \mathrm{~K}$ & 3 & 374005 & 771754 & middle Potomac & -37 & -192 & -259 & SN \\
\hline $52 \mathrm{~L}$ & 9 & 374508 & 772131 & Aquia & 24 & -25 & -45 & $\mathrm{P} 2$ \\
\hline $52 \mathrm{~N}$ & 1 & 380249 & 771829 & Aquia & 83 & -- & -78 & SN \\
\hline $52 \mathrm{~N}$ & 5 & 380624 & 771728 & lower Potomac & 11 & -253 & -286 & SN \\
\hline $52 \mathrm{~N}$ & 6 & 380415 & 771941 & lower Potomac & 12 & -284 & -294 & SN \\
\hline $53 B$ & 6 & 364242 & 771215 & Aquia & 40 & -16 & -21 & P2 \\
\hline $53 \mathrm{~B}$ & 7 & 364242 & 771215 & Aquia & 40 & 19 & 14 & P2 \\
\hline $53 \mathrm{D}$ & 6 & 365530 & 771040 & lower Potomac & 5 & -370 & -380 & SN \\
\hline $53 \mathrm{D}$ & 7 & 365530 & 771040 & lower Potomac & 3 & -325 & -335 & SN \\
\hline 53D & 9 & 365530 & 771040 & middle Potomac & 4 & -109 & -119 & SN \\
\hline
\end{tabular}


Table 1. Characteristics of observation wells in the Fall Zone, Virginia-Continued.

[Datum is sea level, accurate to within 5 feet; latitude and longitude in degrees, minutes, and seconds; SN, statewide water-level observation network (White and Powell, 1997); P1, initial phase of this study (McFarland, 1997); P2, second phase of this study; --, no data]

\begin{tabular}{|c|c|c|c|c|c|c|c|}
\hline \multirow[b]{2}{*}{$\begin{array}{c}\text { Well } \\
\text { number }\end{array}$} & \multirow[b]{2}{*}{ Latitude } & \multirow[b]{2}{*}{ Longitude } & \multirow[b]{2}{*}{ Aquifer } & \multicolumn{4}{|c|}{ Approximate elevation, in feet } \\
\hline & & & & $\begin{array}{l}\text { Water } \\
\text { level }\end{array}$ & $\begin{array}{c}\text { Top of open } \\
\text { interval }\end{array}$ & $\begin{array}{c}\text { Bottom of } \\
\text { open } \\
\text { interval }\end{array}$ & $\begin{array}{c}\text { Source of } \\
\text { information }\end{array}$ \\
\hline 53D 10 & 365530 & 771040 & upper Potomac & 14 & -40 & -50 & SN \\
\hline $53 \mathrm{E} 5$ & 370237 & 771130 & upper Potomac & 37 & -35 & -45 & SN \\
\hline $53 \mathrm{H} \quad 2$ & 372607 & 771406 & middle Potomac & -23 & -87 & -90 & SN \\
\hline $53 \mathrm{~J} \quad 6$ & 373111 & 771046 & middle Potomac & -41 & -170 & -190 & SN \\
\hline $53 \mathrm{~K} 16$ & 373738 & 770828 & middle Potomac & -3 & -210 & -230 & SN \\
\hline $53 \mathrm{M} \quad 1$ & 375922 & 771429 & Aquia & 33 & -12 & -22 & $\mathrm{P} 2$ \\
\hline $54 \mathrm{~A} \quad 1$ & 363722 & 770146 & upper Potomac & -119 & -209 & -219 & $\mathrm{SN}$ \\
\hline $54 \mathrm{~K} \quad 6$ & 374328 & 770128 & middle Potomac & -43 & -336 & -382 & $\mathrm{SN}$ \\
\hline $54 \mathrm{~L} \quad 5$ & 374806 & 770348 & middle Potomac & -15 & -367 & -377 & SN \\
\hline $54 \mathrm{~L} \quad 10$ & 374739 & 770527 & $\begin{array}{c}\text { Chickahominy- } \\
\text { Piney Point }\end{array}$ & 43 & -34 & -44 & $\mathrm{P} 2$ \\
\hline $54 \mathrm{Q} 19$ & 382103 & 770254 & Aquia & -6 & -158 & -178 & SN \\
\hline $54 \mathrm{Q} 21$ & 382129 & 770058 & Aquia & -14 & -177 & -197 & $\mathrm{SN}$ \\
\hline 54Q 23 & 381915 & 770203 & Aquia & -13 & -181 & -201 & $\mathrm{SN}$ \\
\hline $54 \mathrm{R} \quad 2$ & 382341 & 770324 & lower Potomac & -63 & -711 & -731 & SN \\
\hline
\end{tabular}

Water levels in 33 of the observation wells in the Fall Zone were measured as part of a statewide waterlevel observation network ( $\mathrm{SN}$ on table 1) that is maintained as part of a cooperative agreement between USGS and DEQ. A large amount of water-level and other data has been collected from the statewide network over periods as long as several decades from some wells (White and Powell, 1997). For this study, general spatial trends in the present-day head distribution were estimated on the basis of the most recently measured water level in each well at the time of compilation (1998). Because the network wells are measured with varying frequency and over different time periods, dates of the included measurements range from 1995 through 1998. Water levels in some wells can vary by several feet over short-term (1- to 4-yr) periods because of seasonal fluctuations in shallow wells and gradual declines in deep wells. Calculated water-level elevations are accurate only to within $5 \mathrm{ft}$, however, and general spatial trends in head distribution probably are not affected significantly by short-term water level variations.

Water levels were measured in 12 additional observation wells as part of this study. Five of the wells are located near the James River and are among those constructed as part of the initial phase of the study (P1 on table 1) during 1995-96 (McFarland, 1997). During the second phase of the study, instantaneous water levels in these wells continued to be measured approximately quarterly through September 1998 using a hand-held steel-measuring tape. Also during the second study phase, instantaneous water levels were measured approximately monthly in seven additional observation wells (P2 on table 1) from May 1997 through September 1998. Six of the observation wells were constructed at the locations where drilling was conducted as part of the second study phase. Finished depths of these wells range from 52.54 to $115.65 \mathrm{ft}$ below land surface. The wells are cased with 2-inch inside-diameter polyvinyl chloride (PVC), which is 
slotted along the bottom 5-10 ft. The slotted intervals were sand packed, and the casing was grouted with bentonite to land surface. The seventh observation well (well number 52L 9) consists of an existing unused water-supply well.

Approximate median water-level elevations were calculated for each of the observation wells measured for this study (table 1) and were used similarly to data from the statewide network wells to estimate general spatial trends in head distribution. In addition, instantaneous water levels were examined to determine short-term variations and to infer the timing of recharge.

Observation-well construction and water-level data are on file at the Richmond, Va., office of the USGS and are stored in the USGS National Water Information System (NWIS) computer data base. In addition, statewide-network well data are published annually in the USGS Water-Data Report (White and Powell, 1997).

Ground-water flow in the Fall Zone was simulated using MODFLOW, a modular threedimensional finite-difference ground-water-flow model developed by the USGS (McDonald and Harbaugh, 1988), along with information from the descriptions of the hydrogeologic framework and ground-water-flow system presented in this report. Computer programs solve a series of equations for hydraulic heads and rates and volumes of ground-water flow in aquifer cells.

\section{HYDROGEOLOGIC FRAMEWORK}

The Fall Zone in Virginia encompasses the western margin of a thick sequence of stratified sediments that forms a hydrogeologic framework of aquifers and confining units and that is underlain by a basement of largely crystalline bedrock. An unconfined aquifer composed of Tertiary- to Quaternary-age, generally coarse-grained surficial sediments is incised to depths of several tens of feet into underlying confined aquifers and intervening confining units. As a result, subcrop areas of some confined aquifers are present along parts of major rivers.

Confined aquifers and confining units were designated by the names of their principal corresponding geologic formations to facilitate comparisons to previous studies, but at some locations are composed wholly or in part of sediments belonging to different geologic formations. The Yorktown-
Eastover, Chickahominy-Piney Point, and Aquia confined aquifers, and the Yorktown, Calvert, and Nanjemoy-Marlboro confining units, generally consist of Tertiary-age marine deposits of poorly sorted, glauconitic sand with varying amounts of shell, silt, and clay that are present to elevations as low as $-300 \mathrm{ft}$. The aquifers are distinguished from the confining units primarily in being coarser grained and having a greater shell content.

The upper Potomac, middle Potomac, and lower Potomac confined aquifers, and the upper Potomac, middle Potomac, and lower Potomac confining units, generally consist of Cretaceous-age fluvial and deltaic deposits of medium-to-coarse-grained quartz sand with varying amounts of gravel, silt, and clay that are present to elevations as low as $-1500 \mathrm{ft}$ and that belong mostly to the Potomac Formation. The aquifers include zones of relatively concentrated but discontinuous sand-rich beds, and the confining units include zones of relatively concentrated but discontinuous clay-rich beds.

\section{Regional Setting}

At the Fall Line, bedrock from the Piedmont dips beneath a seaward-thickening wedge of largely unconsolidated sediments that underlie the Coastal Plain (fig. 2). Coastal Plain sediments were deposited during a series of transgressions and regressions by the Atlantic Ocean that resulted from changes in sea level. The sediment wedge stretches from Cape Cod, Mass., southward to the Gulf of Mexico, and extends offshore to the continental shelf. The thickness of the sediment wedge in Virginia ranges from near zero at the Fall Line to more than $6,000 \mathrm{ft}$ along the Atlantic Coast (Onuschak, 1972).

The sediments consist of eastward-dipping but largely undeformed stratified deposits. A thick sequence of nonmarine strata primarily of Cretaceous age is overlain by a much thinner sequence of marine strata of Tertiary age (Meng and Harsh, 1988). This sequence is in turn overlain by a veneer of nearly flatlying surficial deposits of Tertiary through Quaternary age.

The Quaternary-age sediments constitute a steplike succession of terraces and intervening scarps that parallels the coast and major streams and dominates the topography of the Coastal Plain (Johnson and Ramsey, 1987). The terraces decrease in elevation toward the 

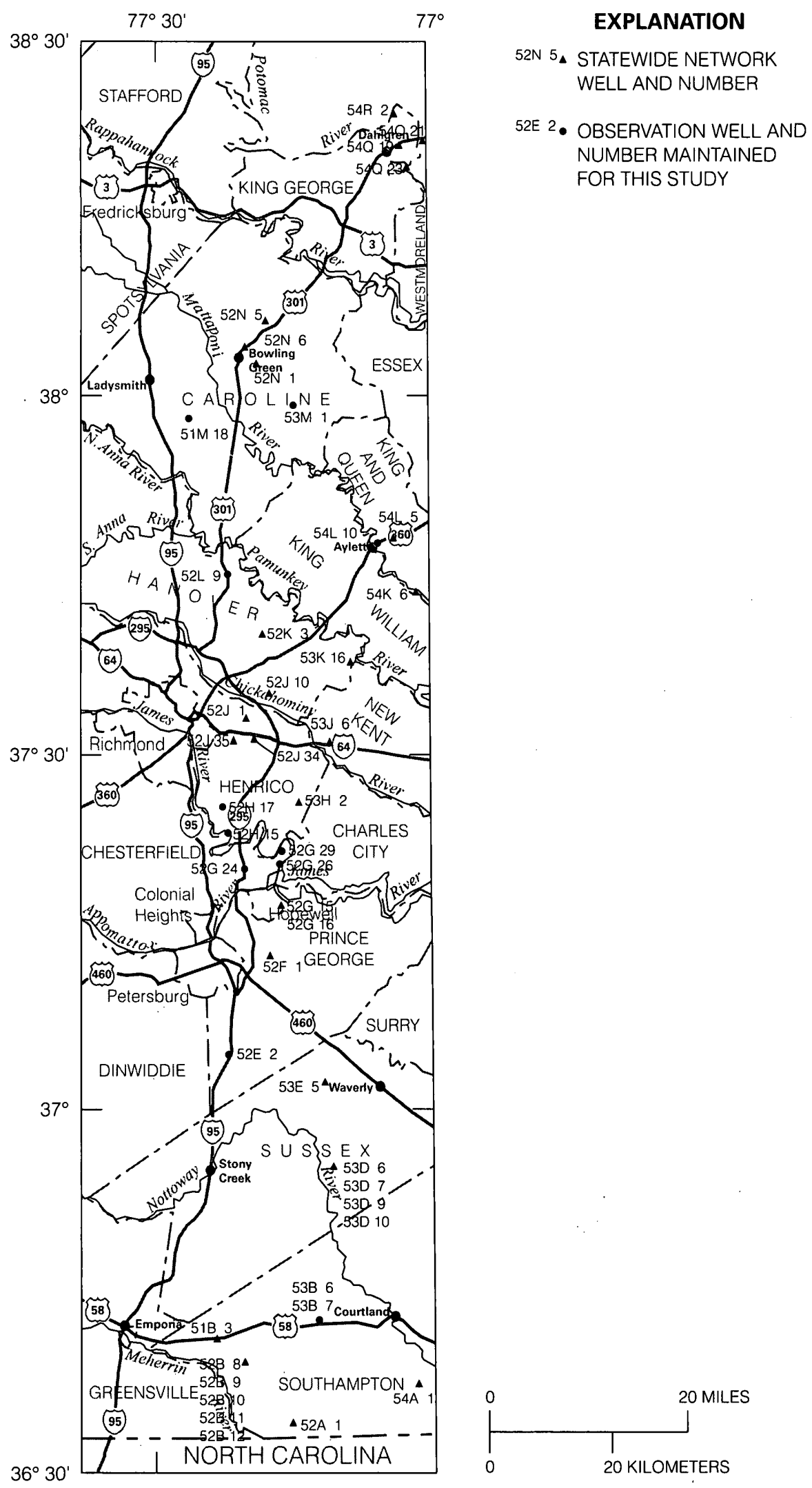

Figure 6. Locations of water-level observation wells in the Fall Zone of Virginia. 
coast and major streams, and-decrease in age with lower elevation. Terrace sediments were deposited at successively lower elevations as a result of sea-level decline. The scarps were initially cut into the older formations as shorelines but were then subjected to subaerial erosion and are now obscured in places.

The Coastal Plain sediment sequence was classified by Meng and Harsh (1988), and later modified by Harsh and Laczniak (1990), into a hydrogeologic framework of aquifers and confining units (fig. 2). Permeable sediments from which significant amounts of water can be drawn are considered to be aquifers, and less permeable sediments that restrict ground-water flow are regarded as confining units. Because of their great thicknesses and large areal extents, Coastal Plain aquifers provide a widely used ground-water supply (Heath, 1984).

Relations between the aquifers and confining units and their corresponding geologic formations in the Coastal Plain in Virginia were established by Meng and Harsh (1988) and later modified by Hamilton and Larson (1988) and Harsh and Laczniak (1990). Although aquifers and confining units generally are named to correspond to their principal geologic formations, they are delineated on the basis of the hydrologic characteristics of the sediments, whereas geologic formations are delineated on the basis of the depositional history of the sediments. Because of variations in sediment composition and hydrologic characteristics, the sediments that compose a given aquifer or confining unit do not coincide precisely in all areas with the sediments that compose the geologic formation of the same name.

Harsh and Laczniak (1990), after Meng and Harsh (1988), describe the aquifers and confining units as follows. The Columbia aquifer constitutes the major surficial aquifer in the Virginia Coastal Plain (fig. 2) and is unconfined. This aquifer incorporates a series of mostly Quaternary-age surficial deposits that are areally extensive only in the eastern part of the Coastal Plain and that are restricted to floodplains and local terraces adjacent to major rivers within the Fall Zone. The Columbia aquifer provides water principally for domestic, agricultural, and small municipal supplies.

The Yorktown-Eastover, Chickahominy-Piney Point, and Aquia aquifers, and the Yorktown, Calvert, and Nanjemoy-Marlboro confining units, mostly incorporate Tertiary-age marine deposits. The Chickahominy-Piney Point aquifer and the Aquia aquifer generally are confined throughout most of the Coastal Plain (fig. 2), whereas the Yorktown-Eastover aquifer is confined only beneath the eastern part of the Columbia aquifer but unconfined in the Fall Zone where it crops out along uplands that separate the major rivers. Hence, the unconfined part of the Yorktown-Eastover aquifer makes up the part of the surficial aquifer not represented by the Columbia aquifer. In addition, small parts of the ChickahominyPiney Point aquifer and the Aquia aquifer may be unconfined in narrow outcrop areas adjacent to some segments of major rivers. The Yorktown-Eastover, Chickahominy-Piney Point, and Aquia aquifers provide water for relatively small but locally important municipal and industrial supplies, as well as domestic and agricultural supplies.

Additional sediments of Cretaceous to Tertiary age compose the Saint Marys-Choptank, Peedee, and Virginia Beach aquifers, and the Saint Marys, Peedee, and Virginia Beach confining units. These aquifers and confining units are restricted to eastern parts of the Coastal Plain in Virginia and are not regionally extensive, but the aquifers provide water for some locally significant municipal and industrial supplies, as well as smaller domestic and agricultural supplies.

The Brightseat-upper Potomac, middle Potomac, and lower Potomac aquifers, and the Brightseat-upper Potomac, middle Potomac, and lower Potomac confining units, mostly incorporate the Cretaceous-age Potomac Formation consisting of fluvial and deltaic deposits. The aquifers are confined throughout most of the Coastal Plain (fig. 2). Small parts of the middle Potomac aquifer may be unconfined in narrow outcrop areas adjacent to major rivers in the Fall Zone. The Brightseat-upper Potomac, middle Potomac, and lower Potomac aquifers are the principal ground-water resource of the Virginia Coastal Plain; they provide approximately $80 \mathrm{Mgal} / \mathrm{d}$ (McFarland and Focazio, 1993) for major industrial and municipal supplies and represent about 90 percent of the water supplied from Coastal Plain aquifers in Virginia.

\section{Unconfined Aquifer}

The unconfined aquifer in the Fall Zone consists of surficial deposits of Tertiary to Quaternary age that span the entire Coastal Plain in Virginia (except for narrow outcrop areas of older formations along some segments of major rivers). The surficial deposits 
occupying uplands are distinct from those occupying lowlands (fig. 5). The uplands are underlain by fluviodeltaic and nearshore marine sediments belonging to the Yorktown and Bacons Castle Formations (Johnson and Ramsey, 1987) and the Eastover Formation (S.J.

Schindler, U.S. Geological Survey, oral commun., 1995) and include parts of the upper and middle Coastal Plain terraces defined as the Midlothian Uplands, Richmond Plain, and Norge Uplands (Johnson and Ramsey, 1987). Lithologic descriptions indicate that the upland formations consist in some areas of well-sorted quartz sand and in other areas of poorly sorted quartz sand and gravel having dense, cohesive silt and clay. By contrast, lowlands that flank the major rivers extending across the Fall Zone are underlain by a series of mostly Quaternary-age terrace and floodplain deposits (Mixon and others, 1989) and include parts of the lower Coastal Plain terraces defined as the Lackey, Grove, and Grafton Plains and the Huntington and Todds Flats (Johnson and Ramsey, 1987). Lithologic descriptions indicate that the lowland deposits consist primarily of very poorly sorted sand, gravel, cobbles, and boulders with noncohesive silt and clay.

The margin that forms the westernmost extent of the surficial deposits is commonly referred to as the Fall Line, even though it does not precisely correspond to the actual locations of falls and rapids along some streams: headward erosion has displaced falls and rapids upstream of the points at which the streams cross from Piedmont bedrock onto Coastal Plain sediments. The configuration of the Fall Line is complex (fig. 5) and is characterized by lobate extensions of the upland deposits, known as caps, that are present along drainage divides and separated by exposures of the underlying bedrock in the valley floors. At some locations, the base of the caps possibly consists of sediments belonging to deeper formations that comprise confined aquifers farther east. In addition, several miles farther westward of the Fall Line into the Piedmont, the upland deposits have been mapped (Mixon and others, 1989) as isolated erosional remnants, or outliers, that also cap drainage divides. Bedrock throughout the Piedmont is overlain by a mantle of residual weathered material, referred to as saprolite, as thick as several tens of feet. Where caps and outliers of Coastal Plain sediments are present, they overlie the saprolite (fig. 2).
Deposition of the upland sediments during the Tertiary period was followed by a purictuated history of erosion and deposition during the Quaternary period (Johnson and Ramsey, 1987). During recurring sealevel declines, streams were incised to successively lower elevations through the upland sediments and into underlying predominantly fine-grained marine sediments. Shorelines cut into and truncated the upland sediments to form erosional scarps that extend downward into the marine sediments. Following an interval of active incision, lowland sediments were deposited on the erosional surface as scarp-bounded floodplains and terraces. Resumed sea-level decline resulted in further incision and subsequent floodplain and terrace deposition at lower elevations, producing a step-like succession of terraces and intervening scarps.

Toward the downstream segments of the major rivers, primarily east of the Fall Zone, the lowland deposits broaden markedly and coalesce along a southwestward-trending lineament (Mixon and others, 1989), commonly referred to as the Surry scarp, and thereby form a continuous and regionally extensive cover of Quaternary-age surficial deposits to the east. The southwesternmost part of the Surry scarp in Virginia lies within the southern part of the Fall Zone (fig. 5). Surficial sediments east of the Surry scarp were deposited primarily during interglacial periods as a result of sea levels that were stabilized above the present-day elevation.

Ground water is present under unconfined conditions in both the upland and lowland surficial deposits within the Fall Zone. Harsh and Laczniak (1990), after Meng and Harsh (1988), generally designated the unconfined aquifer in the lowlands as the Columbia aquifer, on the basis of stratigraphic correlation with the regionally extensive Quaternaryage deposits that constitute the surficial aquifer east of the Surry scarp (fig. 2). Similarly, the unconfined aquifer in the uplands was designated the YorktownEastover aquifer on the basis of stratigraphic correlation with Tertiary-age sediments that constitute the confined Yorktown-Eastover aquifer east of the Surry scarp. Within the Fall Zone, however, the lowland and upland deposits together function hydraulically as a single surficial unconfined aquifer. 


\section{Water Table}

The geometric configuration of the unconfined aquifer in the Fall Zone is complex. The lower part of the surficial deposits contains ground water under saturated conditions and is regarded as the unconfined aquifer. Accordingly, the top of the aquifer is represented by the water table. Because of local variations in recharge and discharge, the shape of the water table probably varies greatly. Partly on the basis of water levels in closely spaced wells open to the unconfined aquifer, the shape of the water table was found to be generally subparallel to the land surface across a local-scale area surrounding the James River within the Fall Zone during the initial phase of this study (McFarland, 1997). During the second phase of the study, however, the same level of detail was not continued to similarly characterize other parts of the Fall Zone. Although the shape of the water table cannot be delineated accurately on a regional scale across the entire Fall Zone, it is assumed to be subparallel to the land surface (see section "Ground-Water Flow").

The unconfined aquifer in the Fall Zone is hydraulically contiguous with the unconfined aquifer in the Piedmont: the water table positioned in upland deposits within the Coastal Plain extends westward into the Piedmont, where it generally is positioned within the saprolite. Where Coastal Plain sediment caps and outliers overlie saprolite in the Piedmont, they function hydraulically as a single unconfined aquifer overlying the bedrock (fig. 2).

\section{Aquifer Base}

The base of the unconfined aquifer in the Coastal Plain is at the contact between the bottom of the surficial deposits and the top of predominantly finegrained marine sediments that generally compose the uppermost confining unit (fig. 2). Because of its complex depositional history, the geometric configuration of the base of the unconfined aquifer within the Fall Zone also is complex and, similar to the water table, cannot be delineated accurately on a regional scale across the entire Fall Zone. Although the lateral extents of individual terraces and floodplains can be inferred from the positions of erosional scarps, the depths at which they are incised are unknown other than at individual drilling locations.
In order to assess the configuration of the base of the unconfined aquifer, terrain conductivity surveys were conducted (see section "Methods of Investigation") to vertically delineate the surficial deposits along transects crossing several of the largest rivers in the Fall Zone (fig. 5). Analysis of the conductivity measurements assumes that materials having different electrical conductivities are present as layers beneath the land surface. Measured terrain conductivity represents a composite value of the conductivities of the individual layers.

In order to analyze conductivity measurements to infer layer depths and thicknesses, two distinct but complementary numerical techniques are commonly employed (Interpex Limited, 1989). Using the "forward" modeling technique, a specified sequence of subsurface layers of known conductivities and thicknesses is used to calculate corresponding terrain conductivity values and thereby indicate the expected range of measured values under given conditions. Using the "inverse" modeling technique, an initial sequence of layers having specified conductivities and thicknesses (the "starting" model) is designated for a given measurement location. Corresponding terrain conductivity values are calculated (as in a forward model) and are compared to the actual terrain conductivities that were measured at the location. Adjusted layer conductivities and thicknesses are then calculated using a least-squares procedure, based on the differences between the calculated and measured terrain conductivities. The adjusted layer conductivities and thicknesses are used to recalculate terrain conductivities, which are once again compared to the measured conductivities. The process is repeated iteratively until the differences between the calculated and measured terrain conductivities are within a specified limit.

Because the results of inverse modeling are affected by characteristics of the starting model, meaningful interpretation depends strongly on advance knowledge of subsurface conditions at the measurement locations. The iterative calculations can converge on solutions that are unrealistic and inaccurate if starting models are used that differ greatly from actual conditions at the measurement locations.

Calculations required to perform both forward and inverse modeling are complex. Accordingly, the terrain conductivity data collected in the Fall Zone were analyzed using EMIX34P (Interpex Limited, 
1989), a computer program developed specifically for analysis of data collected by the Geonics model EM-34 terrain conductivity meter used in this study. Initially, a simple 2-layer, generic forward model, consisting of several locations along a hypothetical transect having different layer conductivities and thicknesses, was constructed to represent the range of conditions in the Fall Zone. On the basis of conditions indicated by the forward model, starting models for inverse modeling of each of the Fall Zone transects were constructed. For all of the transects, two layers were designated to represent coarse-grained surficial deposits overlying fine-grained marine sediments. (A 3-layer model, which would subdivide the surficial deposits into unsaturated and saturated zones, was discounted because the contrast in electrical conductivity between these two zones within the surficial deposits is theorized to be relatively small compared to that between the surficial deposits and the marine sediments.) A starting conductivity of 70 millimohs per meter (mmohs $/ \mathrm{m}$ ) was assigned for the lower layer in all the starting models, on the basis of an examination of borehole resistivity logs of wells located in the Fall Zone. A starting conductivity of $1 \mathrm{mmoh} / \mathrm{m}$ was assigned to the upper layer in all the starting models, to represent the roughly one to two orders-of-magnitude difference in conductivity theorized between the two layers. In order for the starting models to be as realistic as possible, starting layer thicknesses were assigned for each measurement location by qualitatively comparing the measured terrain conductivity values against those produced by the generic model, and thereby inferring how layer thicknesses likely vary along the transect.

Using specified starting layer conductivities and thicknesses, the computer program was executed to perform inverse modeling for each transect. Because the composition of the marine sediments is theorized to remain relatively uniform laterally, the conductivity value of the lower layer was designated to be unchanged during the iterative calculations. By contrast, lithologic composition is expected to vary among upland deposits and different lowland floodplain and terrace deposits. Accordingly, the conductivity value of the upper layer was adjusted during the iterative calculations. In addition, the upper layer thicknesses were adjusted. Lower layer thickness is not adjusted because it is treated numerically as having an infinite value. Iteration ceased when the differences between calculated and measured terrain conductivities were within limits internally specified in the program.

Hydrogeologic sections of the transects were constructed to summarize results of the terrain conductivity surveys and depict the configuration of the base of the surficial deposits (fig. 7). Thicknesses of the surficial deposits calculated by the inverse models were plotted at each terrain conductivity measurement location. (Starting-model thicknesses at the measurement locations also are indicated.) The contact between the surficial deposits and underlying predominantly marine sediments was interpolated between measurement locations and has a complex undulating shape. The horizontal extents of individual floodplains and terraces along each transect were delineated by the positions of erosional scarps at the land surface and were cross-referenced with geologic maps. The surfaces of erosional scarps were inferred to extend downward and to coincide with benches on the top surface of the marine sediments that were cut when the erosion occurred. In addition, the positions of confined aquifers and confining units beneath the transects, as interpreted from electric logs of nearby wells (see section "Methods of Investigation"), were transferred onto the sections.

Inverse-model thicknesses of the surficial deposits range from near zero to approximately $100 \mathrm{ft}$, but at most measurement locations are approximately 20 to $50 \mathrm{ft}$ (fig. 7). Coincidentally, topographic maps indicate a preponderance of sand and gravel quarrying operations in some areas where surficial deposits are thickest. Varying degrees of agreement exist between the inverse-model and starting-model thicknesses but, in most cases, the inverse-model thicknesses are within a realistic range. Because a numerical procedure was used to calculate the inverse-model thicknesses, these values are more quantitatively consistent with the measured terrain conductivities than the starting-model thicknesses, which are qualitatively inferred. At a small number of locations, however, the inverse-model thicknesses obtained initially appeared to be unrealistic. In these instances, small changes to the upper layer conductivities in the starting model and reexecution of the inverse-model program resulted in more realistic thicknesses.

In addition, examination of the final adjusted conductivities of the upper layer calculated by the inverse models indicated that most values are within realistic ranges. Approximately 94 percent of the 
values are less than $10 \mathrm{mmohs} / \mathrm{m}$, and the remaining 6 percent range up to $21 \mathrm{mmohs} / \mathrm{m}$. More than half of the values are between 1 and $6 \mathrm{mmohs} / \mathrm{m}$. The generally low values are consistent with the coarse-grained and well-sorted sediments. The few high values are consistent with surficial deposits that have a relatively large amount of fine-grained material, such as at upland locations where the sediments are highly weathered, or near rivers where the sediments contain large amounts of mud and (or) organic material.

Well-log data indicate that along the three transects that cross the upstream parts of the Mattaponi, Pamunkey, and Chickahominy Rivers (locations A, C, and $\mathrm{E})$, surficial deposits are underlain entirely by the Nanjemoy-Marlboro confining unit (fig. 7). The contrast in electrical conductivity along the contact between the surficial deposits and the fine-grained lowpermeability sediments composing the confining unit is the basis for delineation of the contact using terrain conductivity measurements. More permeable sediments designated as confined aquifers, some possibly having low electrical conductivities, are present at greater depth below the confining unit. Because the surficial deposits are not incised entirely through the confining unit, vertical leakage to and (or) from the confined aquifers could be impeded.

Along another four transects (locations B, D, F, and I), surficial deposits beneath the uplands and most of the terraces are underlain by sediments designated as confining units. Beneath the floodplains and one lowelevation terrace, however, the surficial deposits are underlain by sediments designated as aquifers (fig. 7). Included are the transects that cross the downstream parts of the Mattaponi, Pamunkey, and Chickahominy Rivers (locations B, D, and F), where incision is through the Calvert confining unit into the Chickahominy-Piney Point aquifer, and the transect that crosses Three Creek (location I), where incision is through the upper Potomac confining unit into the upper Potomac aquifer. The floodplain deposits along the Mattaponi, Pamunkey, and Chickahominy Rivers also are generally thicker and more deeply incised than at the corresponding transects upstream (locations A, $\mathrm{C}$, and $\mathrm{E}$ ). Terrain conductivity measurements are not anomalously low where the surficial deposits are underlain by these aquifers. Lithologic descriptions indicate that, although the sediments are designated as aquifers, in many places they include an appreciable proportion of fine-grained material. The transects are located within the westernmost extents of the Chickahominy-Piney Point and upper Potomac aquifers, which provide a significant water supply farther east but are relatively low yielding in the Fall Zone. Hence, the contrast in electrical conductivity between these aquifers and overlying surficial deposits likely is similar in magnitude to that between the confining units and the surficial deposits. Because the surficial deposits are incised partly through the confining units and into the confined aquifers, vertical leakage to and (or) from the aquifers could be enhanced.

Along the two remaining transects, both of which cross the Nottoway River (locations $\mathrm{G}$ and $\mathrm{H}$ ), surficial deposits in some areas are underlain by the Nanjemoy-Marlboro confining unit, but elsewhere are incised entirely through the confining unit and the underlying Aquia aquifer, and partway into the upper Potomac confining unit (fig. 7). Along the upstream transect (location $\mathrm{G}$ ), a large erosional scarp forms the western limits of the Nanjemoy-Marlboro confining unit and Aquia aquifer. Along the downstream transect (location $\mathrm{H}$ ), the confining unit and aquifer are removed beneath the floodplain. Because the surficial deposits are incised through the Aquia aquifer, vertical leakage to and (or) from the aquifer could be enhanced.

\section{Confined Aquifers and Confining Units}

The geometric configurations of confined aquifers and confining units within the Fall Zone were delineated on the basis of interpretations made from existing geophysical (electric) borehole logs and related data from 128 wells (app. 1), as well as from geologic logs from 10 additional wells drilled for this study (app. 2). In order for delineation of the hydrogeologic framework to be spatially consistent, interpretation of both electric logs and geologic logs must account for the geographic locations of the logged wells. The aquifers and confining units considered by this study are regionally extensive. Accordingly, their vertical positions were correlated across distances as great as 50 miles. The lateral continuity of different logged intervals between well locations was examined to indicate strike and dip directions, pinch outs, and other structural features of the aquifers and confining units. In addition, the results of previous geologic mapping and other studies were considered. 
In order to summarize results of well-log interpretation, structural contour maps were constructed to represent the top surfaces of each of the confined aquifers and confining units (figs. 8 through 19). The top surface of basement rock underlying the Coastal Plain sediments also is represented (fig. 20). Although some lithologic descriptions indicate that saprolite may be present above the basement rock and beneath the Coastal Plain sediments at some locations, the saprolite does not appear to be regionally extensive and therefore is not represented.

Many of the aquifers and confining units positioned at relatively high elevations within the Fall Zone are partly or wholly incised in places by major river valleys (figs. 8-17). Aquifer and confining-unit top and bottom surfaces were compared against the land surface to delineate the incised areas. In addition, general trends observed in floodplain and terrace incision from terrain conductivity surveys (see section "Unconfined Aquifer") were used to infer the depths below the land surface at which aquifers and confining units likely were incised. Generally eastward-pointing "V's" along the western limits of the aquifers and confining units indicate where entire thicknesses have been eroded to remove parts of the aquifers and confining units. In aquifer subcrop areas (figs. 11, 13, 15 , and 17), where the entire thickness of a confining unit has been eroded, and the underlying aquifer has been partly eroded and subsequently recovered by floodplain and terrace deposits, the hydraulic connections between aquifers and rivers and streams potentially are enhanced.

To allow comparisons to previous studies in the Virginia Coastal Plain (Meng and Harsh, 1988; Hamilton and Larson, 1988; Laczniak and Meng, 1988; Harsh and Laczniak, 1990), names were assigned to aquifers and confining units in the Fall Zone to correspond to their principal geologic formations. The relations between geologic formations and aquifers and confining units were summarized from west to east for the northern (fig. 21) and southern (fig. 22) parts of the Fall Zone. Some primarily Tertiary-age formations (Ward, 1985) are present only in the northern part of the Fall Zone, generally north of the James River, whereas other late Cretaceous age formations (Powars and others, 1988) are present only in the southern part. In the Fall Zone as throughout the Virginia Coastal Plain, although sediment composition varies within individual formations, aquifers and confining units were delineated to be hydraulically contiguous. As a result, some aquifers and confining units include geologic formations other than those with the same name. The positions of many aquifer-confining unit contacts vary among formations (figs. 21 and 22). Additionally, some aquifers and confining units do not extend entirely to the Fall Line but pinch out farther east, although some of the formations that comprise them continue westward. Relations between geologic formations and specific aquifers and confining units are described below.

Because most of the confined aquifers in the Fall Zone do not span the entire study area (figs. 9, 11, 13, 15,17 , and 19), each confining unit was delineated to extend only as far as the confined aquifer positioned directly beneath it (figs. 8, 10, 12, 14, 16, and 18). Accordingly, each confined aquifer and the confining unit overlying it are described together below. By contrast, previous studies in the Virginia Coastal Plain (Meng and Harsh, 1988; Hamilton and Larson, 1988; Laczniak and Meng, 1988; Harsh and Laczniak, 1990) delineated some confining units that are extended beyond their directly underlying confined aquifers and thereby are positioned vertically adjacent to other confining units without any intervening aquifers. Although the adjacent confining units function hydraulically as a single confining unit, they were delineated separately in order to preserve the correspondence of the confining-unit names with geologic formation names. Without actual geologic logs from which formations can be reliably identified, however, electric log intervals in which adjacent confining units were previously designated often are not clearly distinguishable. Formal recognition of geologic formation designations in the Virginia Coastal Plain generally requires mineralogically and sedimentologically precise lithologic descriptions and detailed biostratigraphic data, which are available for only a very few locations. In addition, because aquifers and confining units are delineated to be hydraulically contiguous, their names still often differ from those of the geologic formations they include, even where the geologic formations are clearly recognized.

\section{Confined Yorktown-Eastover Aquifer and Yorktown Confining Unit}

Intervals were identified on 12 electric logs that were designated to represent the confined part of the Yorktown-Eastover aquifer and the overlying Yorktown 


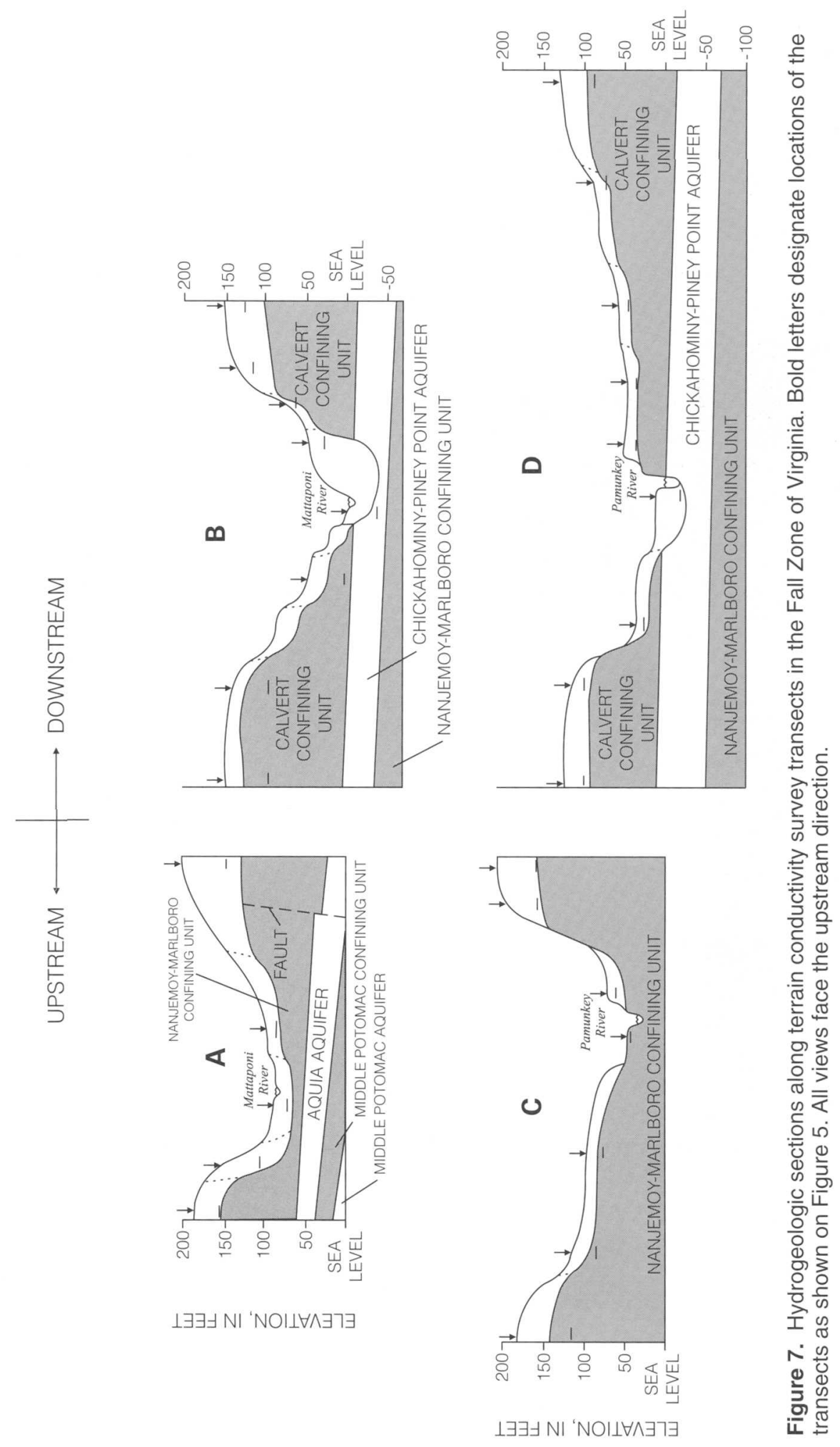




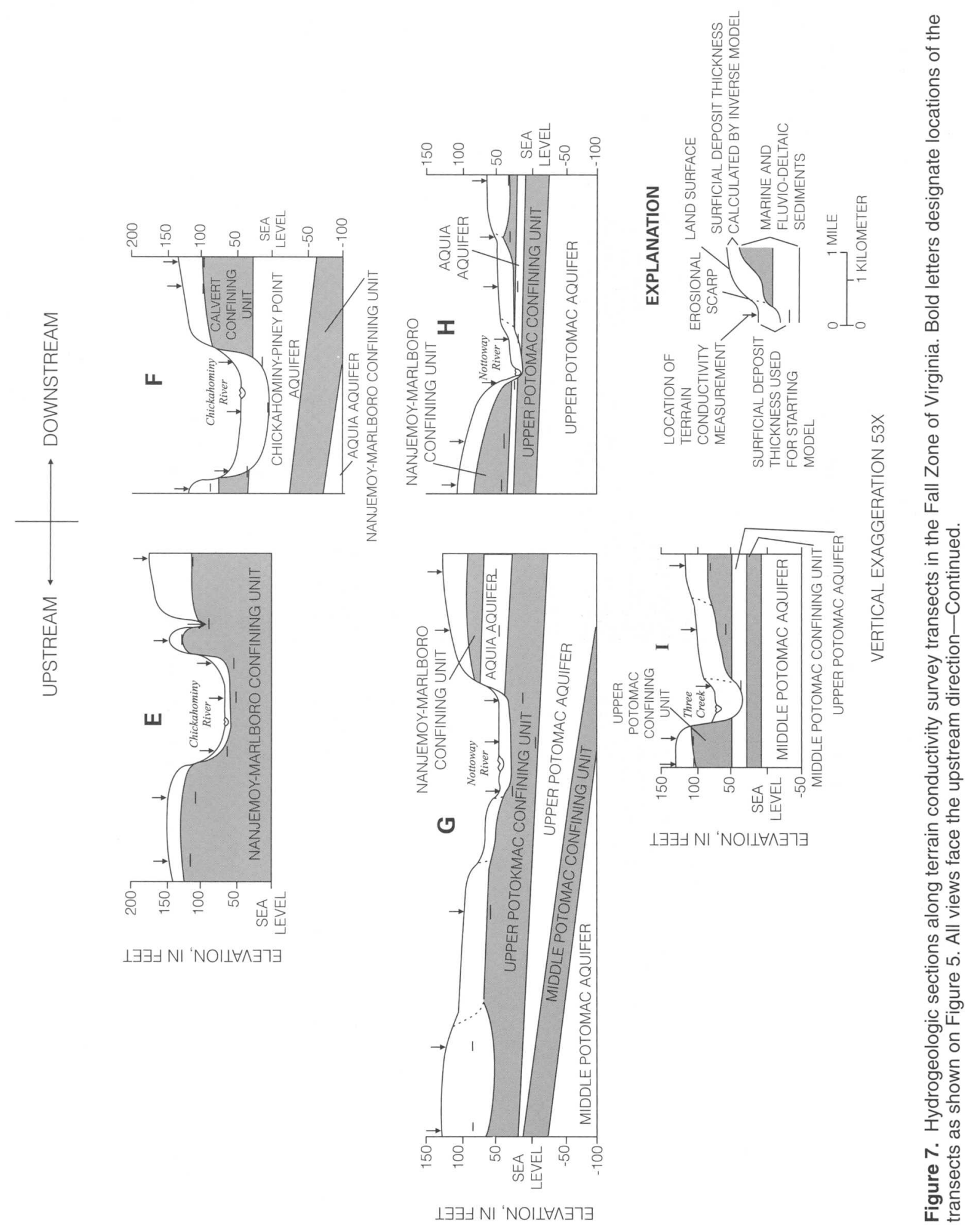


confining unit (app. 1). All 12 logs are of wells located in the far southeastern part of the Fall Zone (figs. 8 and 9), southeast of the Surry scarp (fig. 5). Lithologic descriptions corresponding to both of these intervals indicate the sediments to be primarily of marine origin and to consist generally of glauconitic, partly shelly, and poorly sorted sand with varying amounts of silt and clay.

The Yorktown confining unit is composed of sediments belonging to the Yorktown Formation (fig. 22) and is distinguished from the YorktownEastover aquifer primarily in being finer grained and having a lesser shell content. The Yorktown-Eastover aquifer is composed of sediments belonging to either the Yorktown or Eastover Formations or both.

From an elevation of greater than $80 \mathrm{ft}$ near its western limit, the top of the Yorktown confining unit dips southeastward to near sea level (fig. 8). Similarly, from an elevation of greater than $30 \mathrm{ft}$ near its western limit, the top of the Yorktown-Eastover aquifer dips eastward to near $-50 \mathrm{ft}$ (fig. 9). Both the aquifer and confining unit are incised along part of the Nottoway River near Courtland, Va., and likely either pinch out or are truncated along the Surry scarp.

The vertical positions of the confined part of the Yorktown-Eastover aquifer and the Yorktown confining unit generally correspond to those delineated by previous studies (Meng and Harsh, 1988; Harsh and Laczniak, 1990; Hamilton and Larson, 1988; Laczniak and Meng, 1988). By contrast, the areal extents in this study are less broad and are constrained farther to the east by several miles. Because surficial upland deposits that compose part of the unconfined aquifer in the Fall Zone are stratigraphically correlative to sediments that compose the confined Yorktown-Eastover aquifer (see section "Unconfined Aquifer"), Harsh and Laczniak (1990) after Meng and Harsh (1988) designated both materials as belonging to the same aquifer. Their boundary between the unconfined and confined parts of the aquifer, however, is west of the Surry scarp. In this study, the Surry scarp was interpreted to represent the principal structural control on the western limit of the confined part of the Yorktown-Eastover aquifer and the Yorktown confining unit. Sediments in areas west of the Surry scarp that are stratigraphically correlative with the Yorktown-Eastover aquifer consist of surficial upland deposits (Mixon and others, 1989) and, hence, were designated in this study as part of the unconfined aquifer (figs. 21 and 22).
The hydraulic contiguity between surficial upland deposits and the confined part of the YorktownEastover aquifer is uncertain. Based on regional topographic trends resulting from erosion and deposition during Quaternary time (see section "Unconfined Aquifer"), surficial sediments east of the Surry scarp likely are incised along the scarp (fig. 2). Upland deposits farther west are at least partly truncated along the scarp and, hence, possibly no longer extend eastward at depth to join the confined part of the Yorktown-Eastover aquifer. Locations of logged wells are too widely spaced, however, to define precisely subsurface structural features associated with the Surry scarp, so the designation of the upland deposits as part of the Yorktown-Eastover aquifer by previous studies (Meng and Harsh, 1988; Hamilton and Larson, 1988; Laczniak and Meng, 1988; Harsh and Laczniak, 1990) remains speculative. Alternatively, ground water under unconfined conditions probably is hydraulically contiguous between the upland deposits and lowland deposits across most of the Fall Zone, as well as with unconfined ground water in surficial deposits throughout the rest of the Coastal Plain. Hence, a hydrologic basis exists to designate all surficial deposits in the Coastal Plain that contain unconfined ground water as a single unconfined aquifer (figs. 21 and 22), despite their having diverse stratigraphic relations.

\section{Chickahominy-Piney Point Aquifer and Calvert Confining Unit}

Intervals were identified on 13 electric logs and 1 geologic log that were designated to represent the Chickahominy-Piney Point aquifer, and on 10 electric logs and 1 geologic log that were designated to represent the overlying Calvert confining unit (app. 1). All logs are of wells located in the far northeastern and east-central parts of the Fall Zone (figs. 10 and 11). Lithologic descriptions corresponding to both of these intervals indicate the sediments to be primarily of marine origin and to consist generally of glauconitic, partly shelly, and poorly sorted sand with varying amounts of silt and clay.

The geologic log of well 54L 10 (app. 2) indicates that the interval designated as the Calvert confining unit is composed of fine-grained sediments belonging to the Calvert Formation. The stratigraphically higher Eastover, Saint Marys, and 


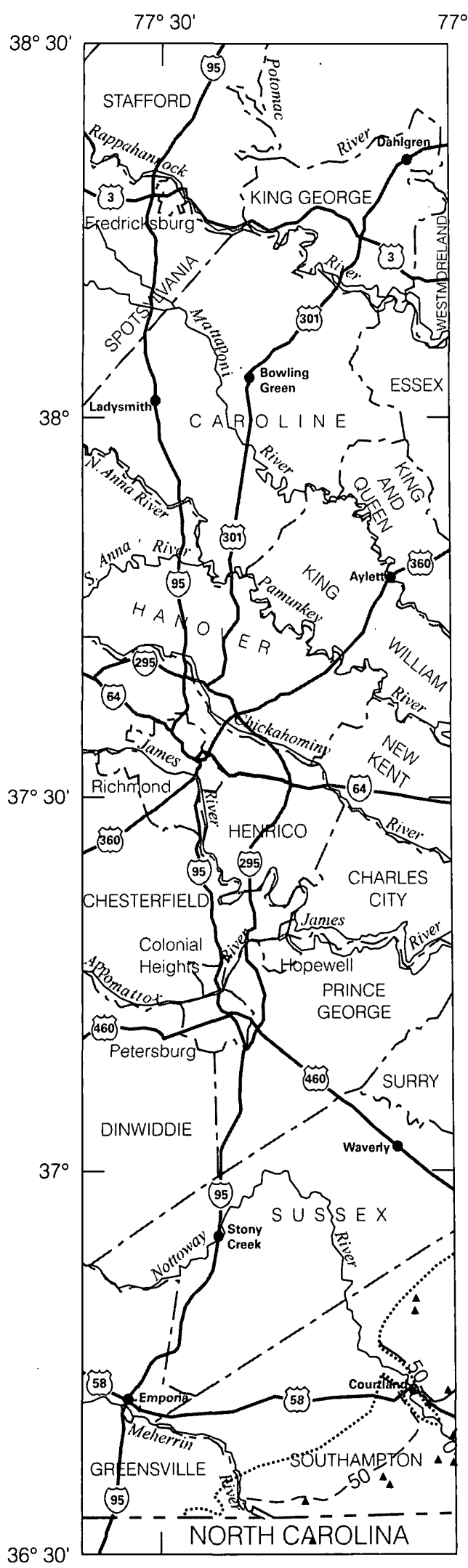

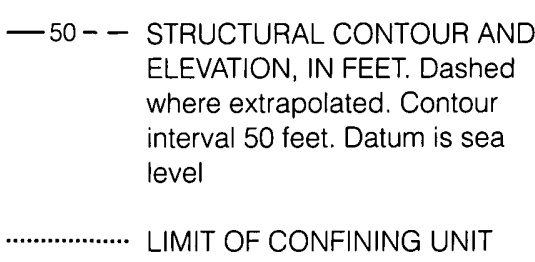

- ElECtRIC WELL LOG INTERSECTING TOP SURFACE OF CONFINING UNIT

Figure 8. Top surface elevation of the Yorktown confining unit in the Fall Zone of Virginia. 


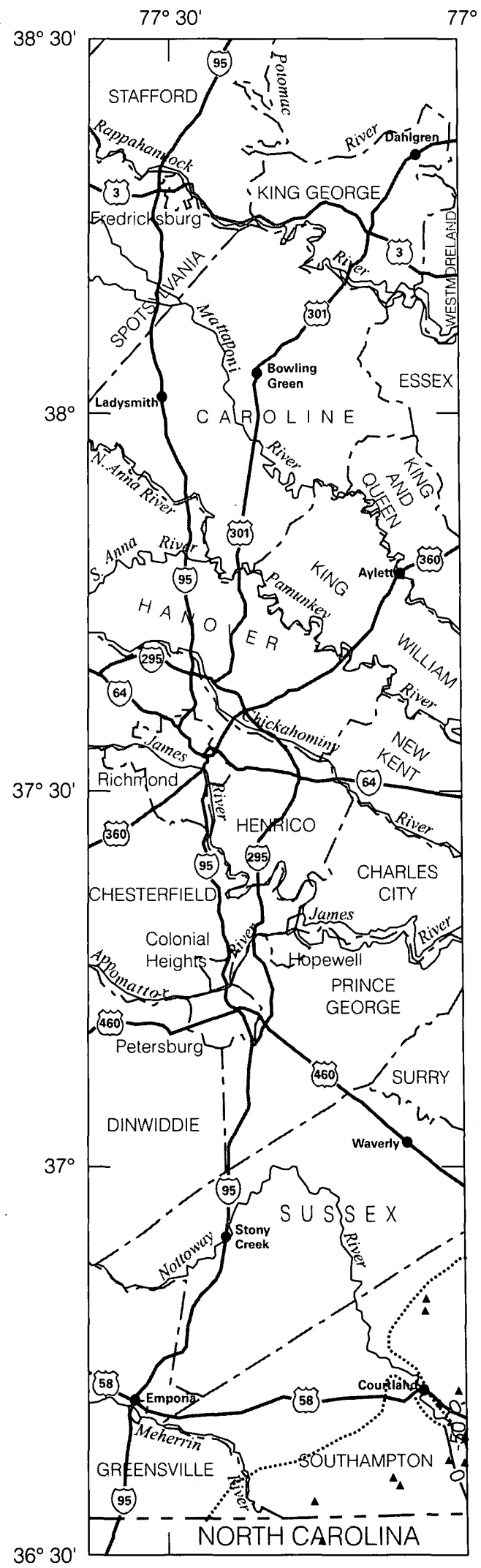
- 50 - STRUCTURAL CONTOUR AND ELEVATION, IN FEET. Contour interval 50 feet. Datum is sea level
LIMIT OF AQUIFER
- ELECTRIC WELL LOG INTERSECTING TOP SURFACE OF AQUIFER

Figure 9. Top surface elevation of the confined Yorktown-Eastover aquifer in the Fall Zone of Virginia. 


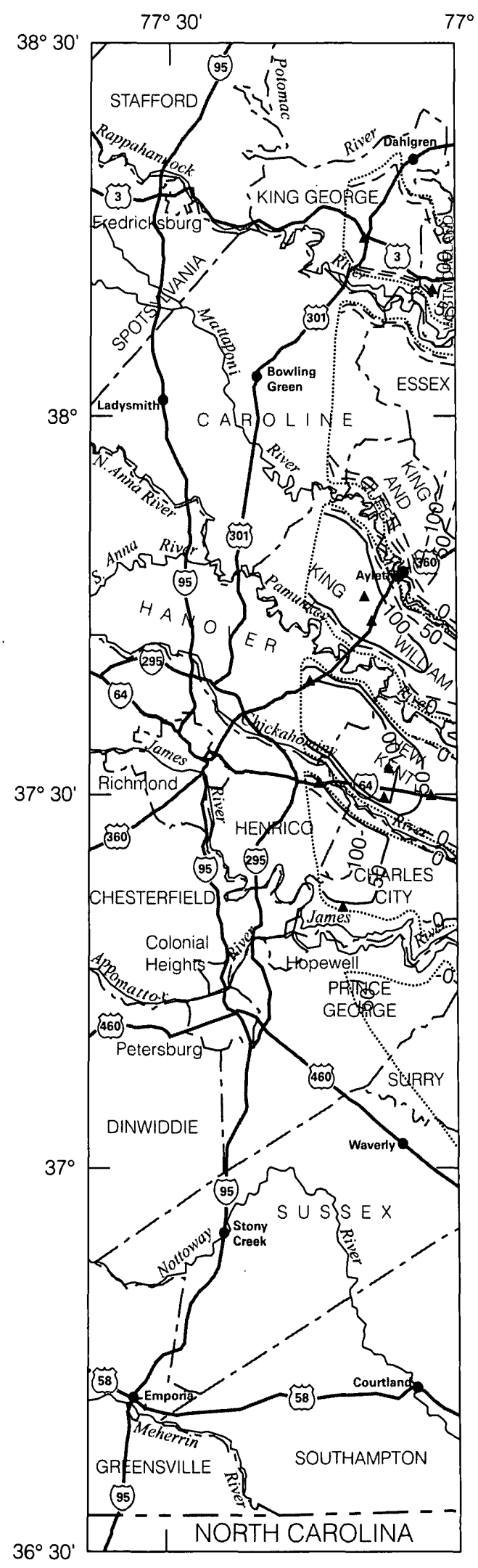

- 50- - STRUCTURAL CONTOUR AND ELEVATION, IN FEET. Dashed where extrapolated. Contour interval 50 feet. Datum is sea level

LIMIT OF CONFINING UNIT

\ ELECTRIC WELL LOG INTERSECTING TOP SURFACE OF CONFINING UNIT

- GEOLOGIC LOG

INTERSECTING TOP SURFACE OF CONFINING UNIT

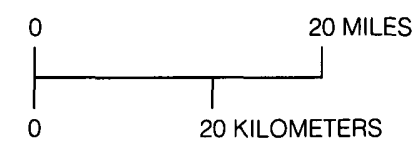

Figure 10. Top surface elevation of the Calvert confining unit in the Fall Zone of Virginia. 

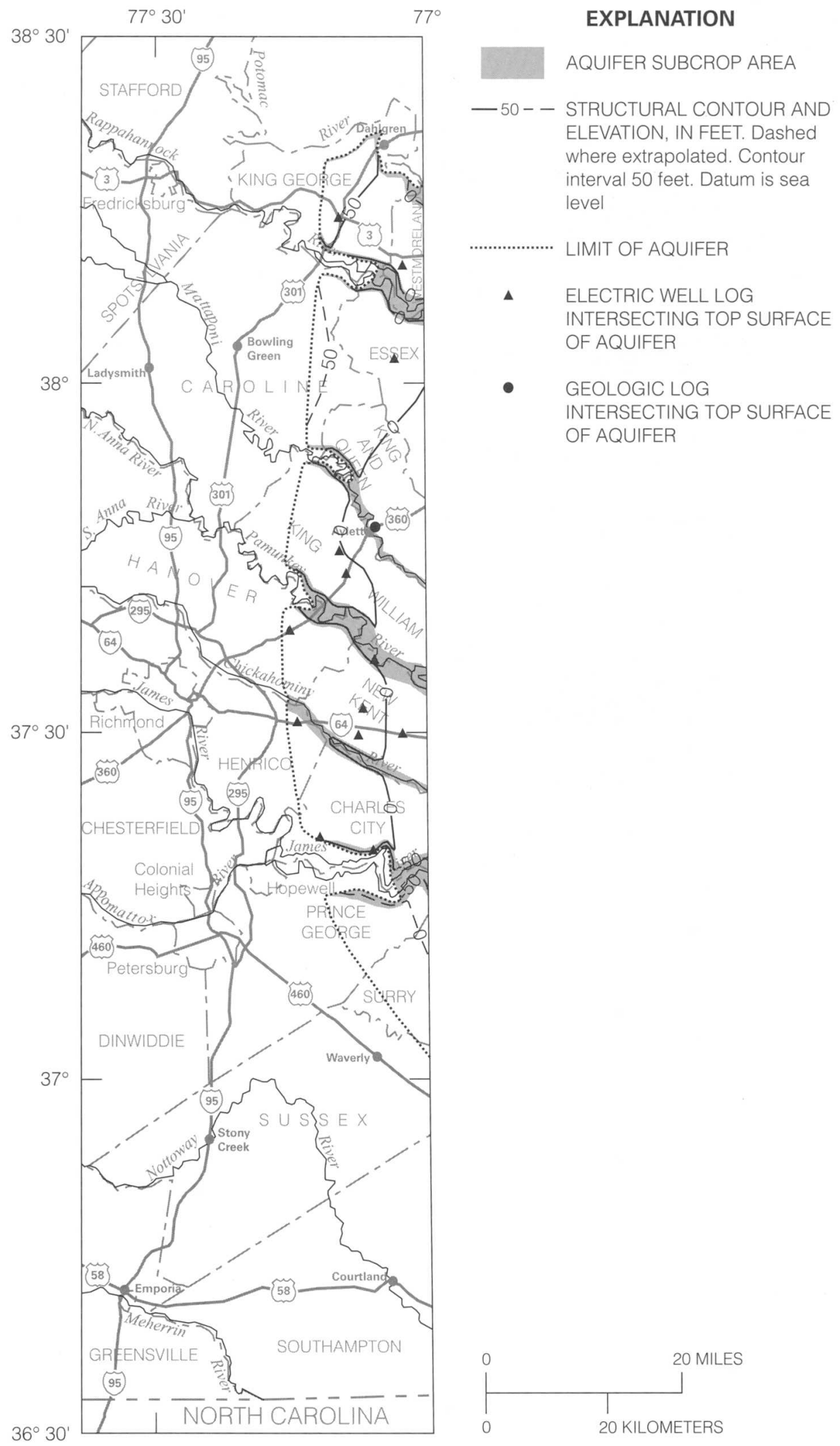

Figure 11. Top surface elevation of the Chickahominy Piney-Point aquifer in the Fall Zone of Virginia. 

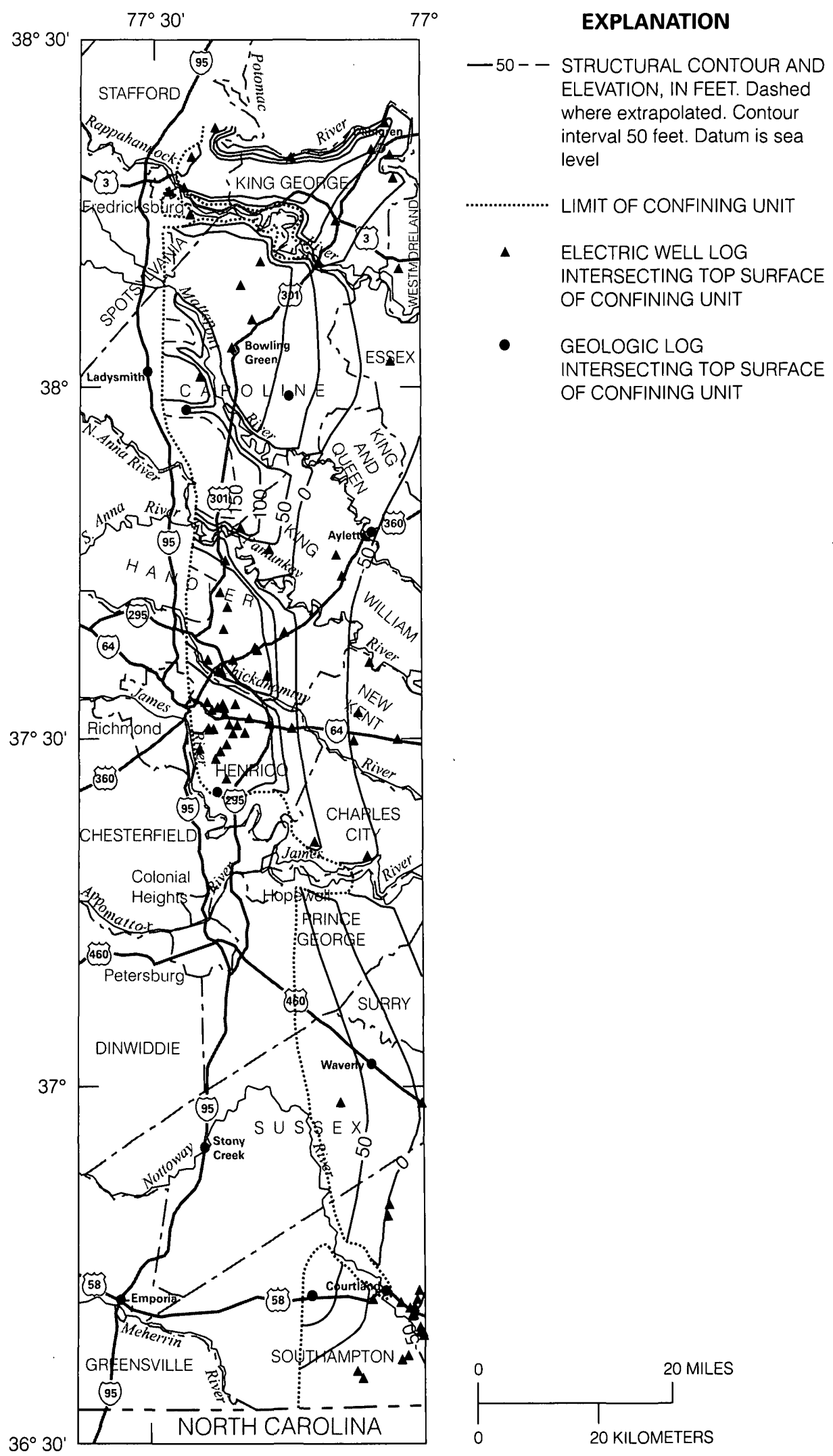

Figure 12. Top surface elevation of the Nanjemoy-Marlboro confining unit in the Fall Zone of Virginia. 


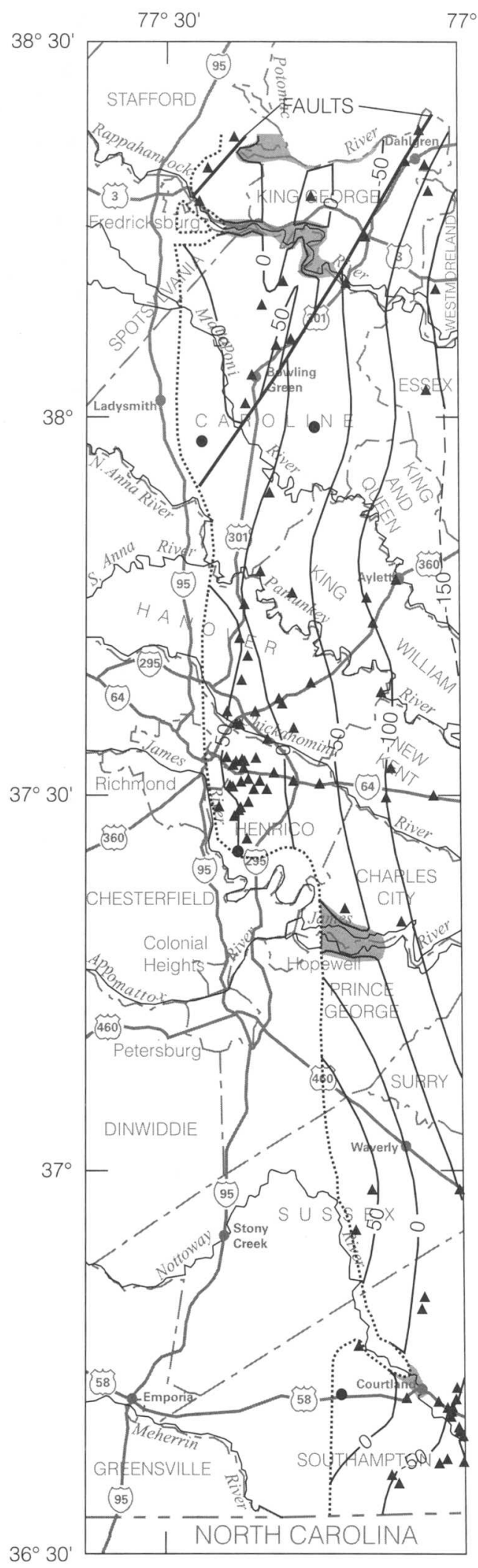

\section{EXPLANATION}

AQUIFER SUBCROP AREA

- 50- - STRUCTURAL CONTOUR AND ELEVATION, IN FEET. Dashed where extrapolated. Contour interval 50 feet. Datum is sea level

LIMIT OF AQUIFER

- ELECTRIC WELL LOG INTERSECTING TOP SURFACE OF AQUIFER

- GeOlogic LOG

INTERSECTING TOP SURFACE OF AQUIFER

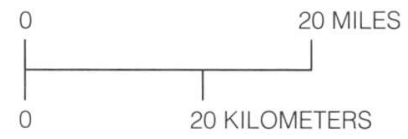

Figure 13. Top surface elevation of the Aquia aquifer in the Fall Zone of Virginia. 

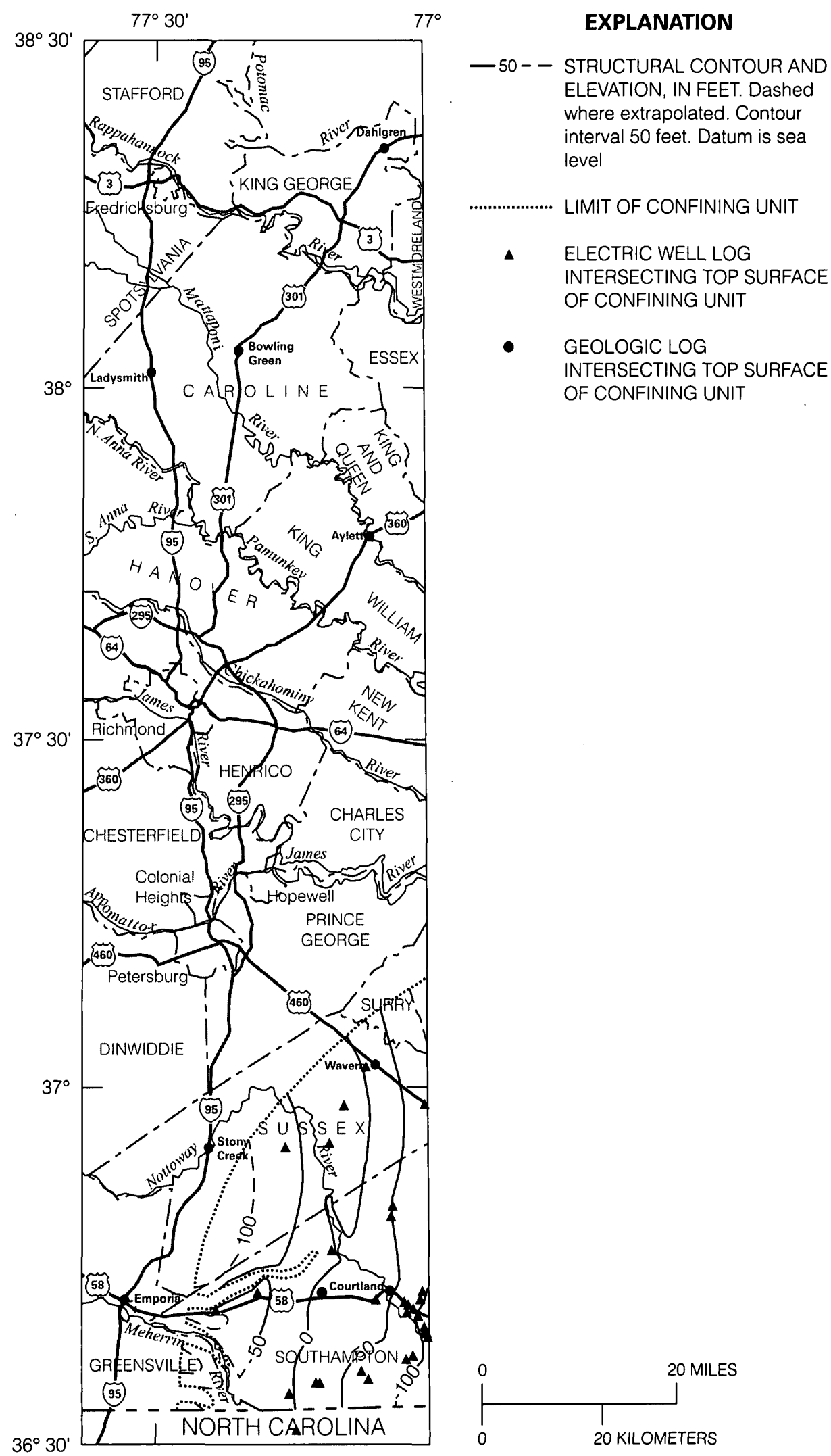

Figure 14. Top surface elevation of the upper Potomac confining unit in the Fall Zone of Virginia. 

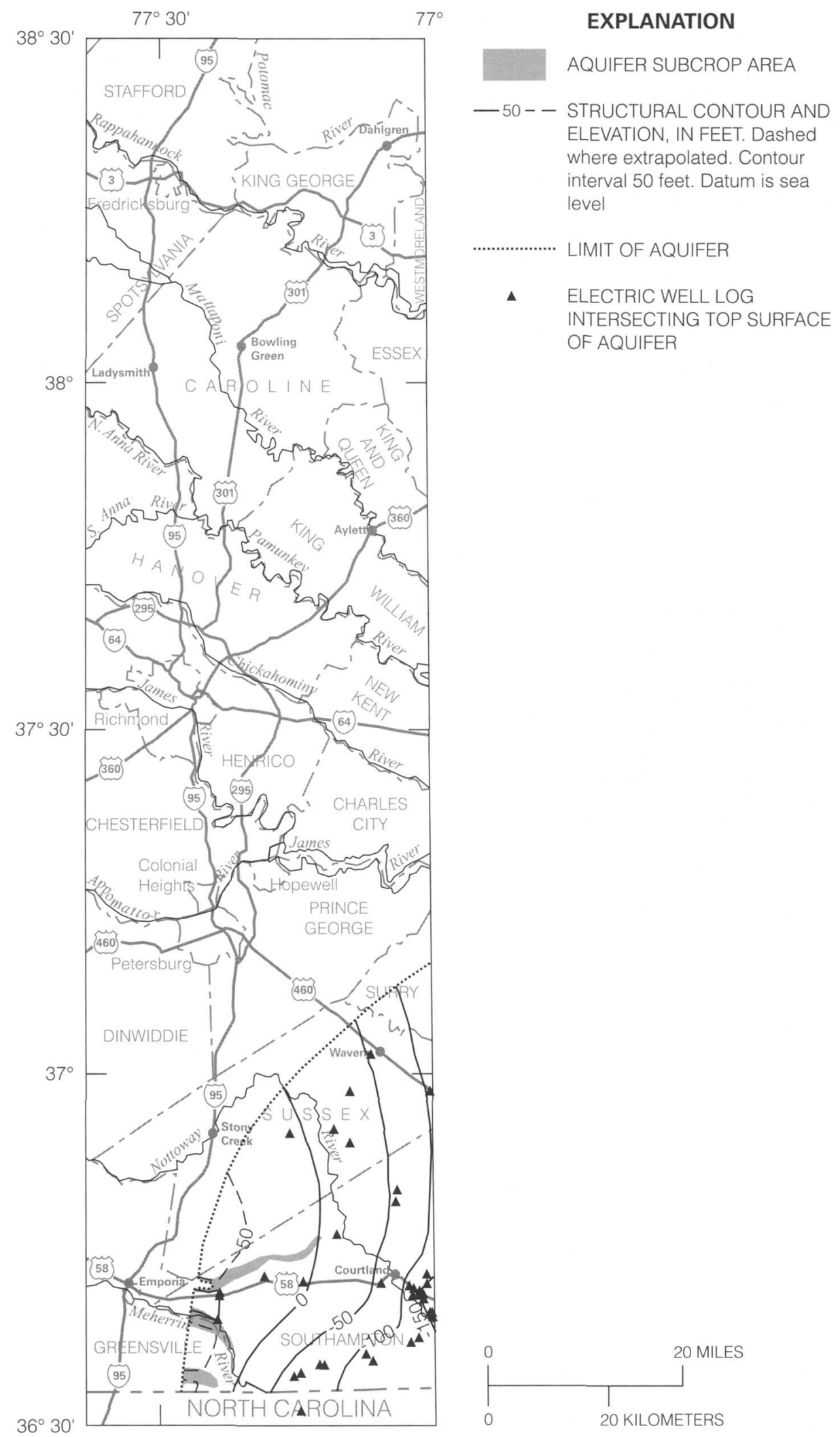

Figure 15. Top surface elevation of the upper Potomac aquifer in the Fall Zone of Virginia. 

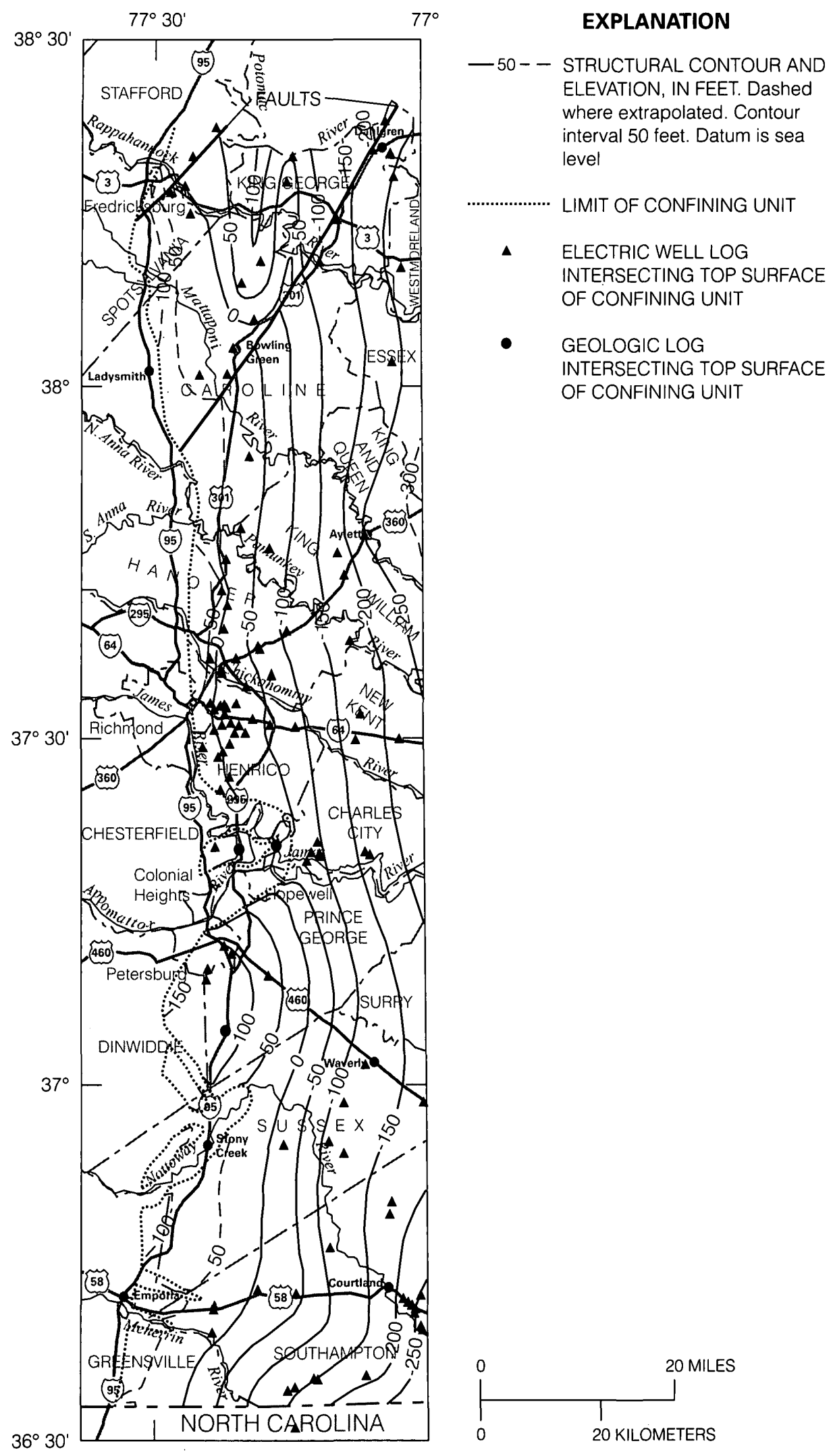

Figure 16. Top surface elevation of the middle Potomac confining unit in the Fall Zone of Virginia. 

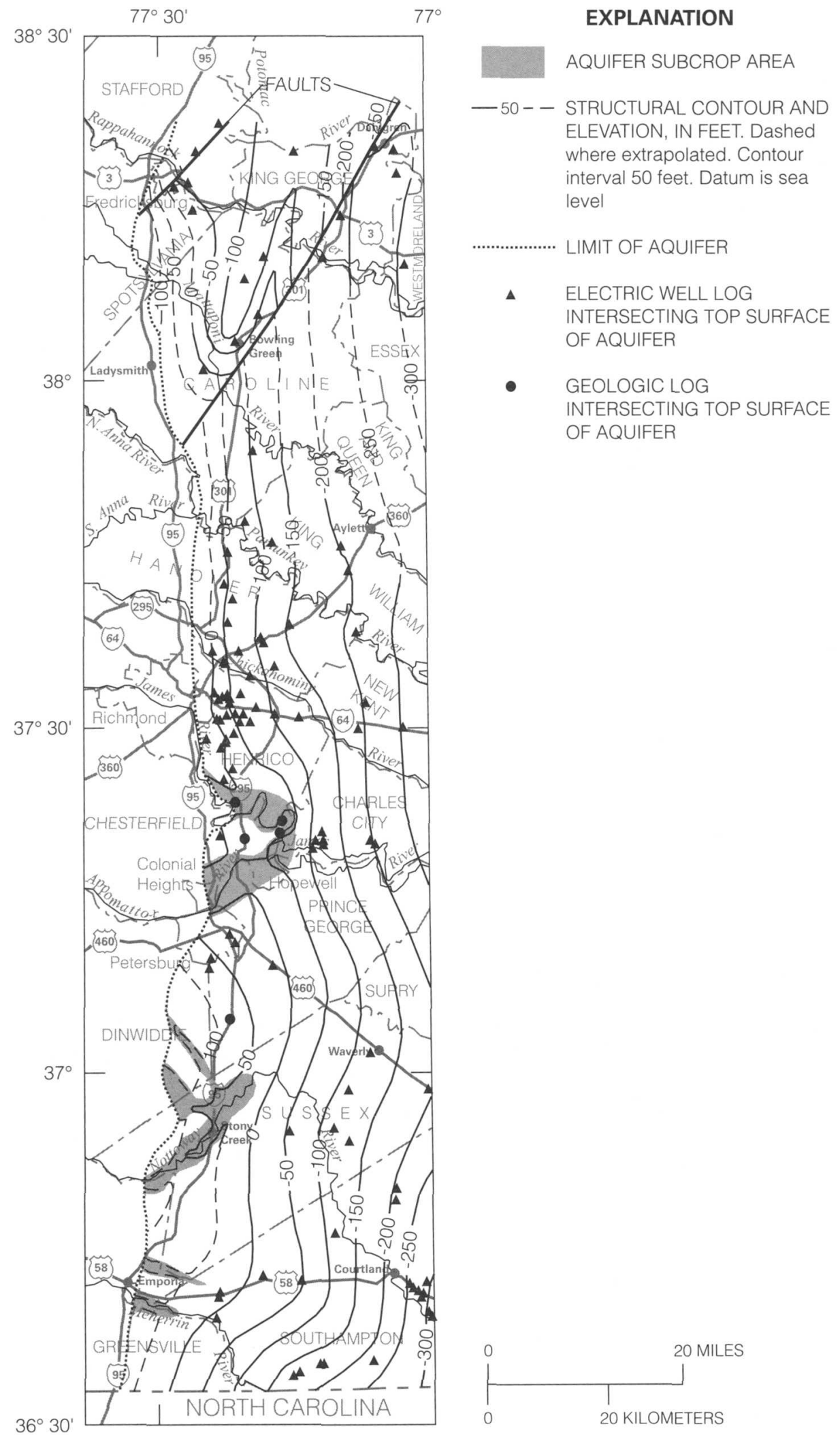

Figure 17. Top surface elevation of the middle Potomac aquifer in the Fall Zone of Virginia. 

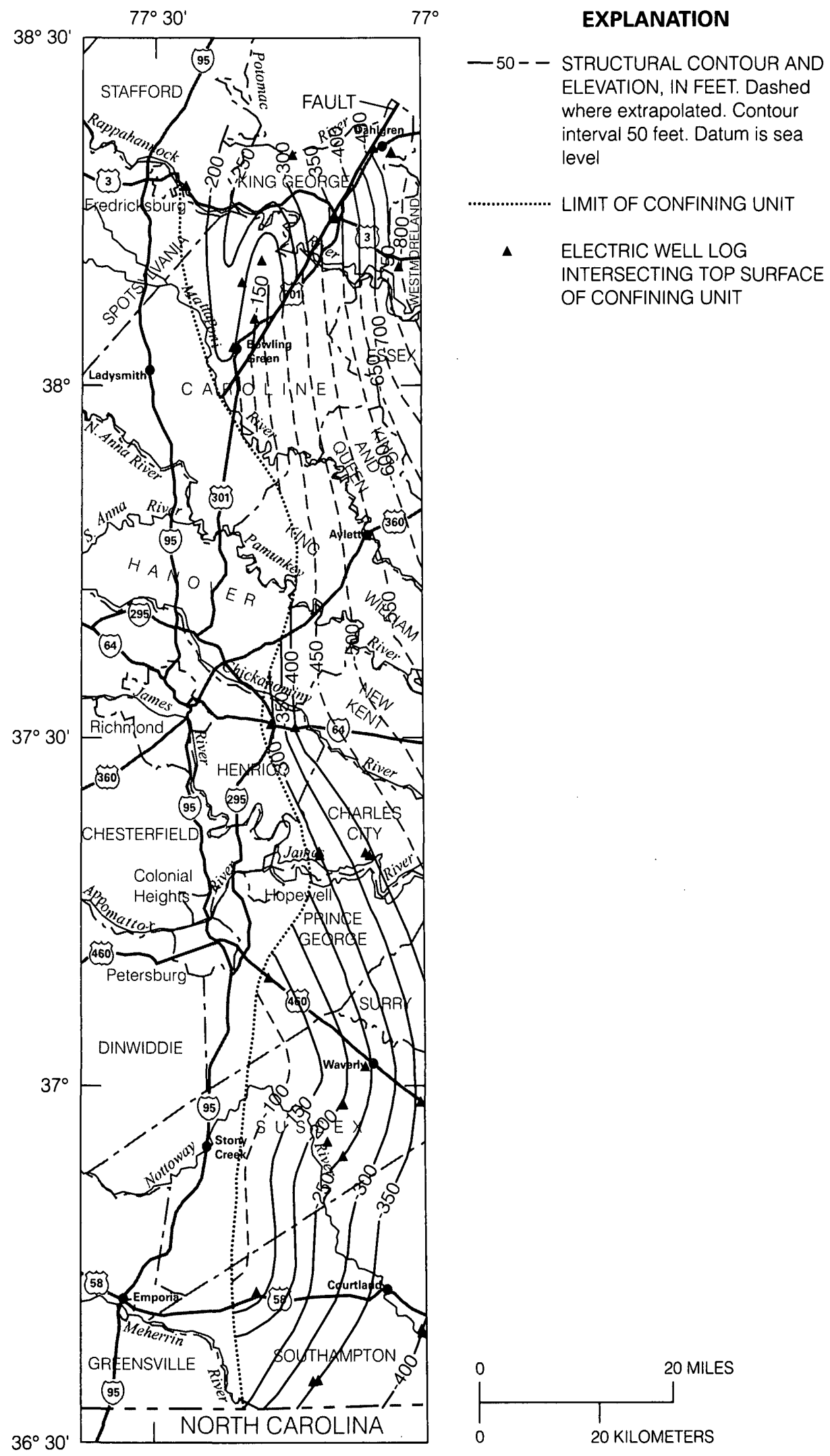

Figure 18. Top surface elevation of the lower Potomac confining unit in the Fall Zone of Virginia. 

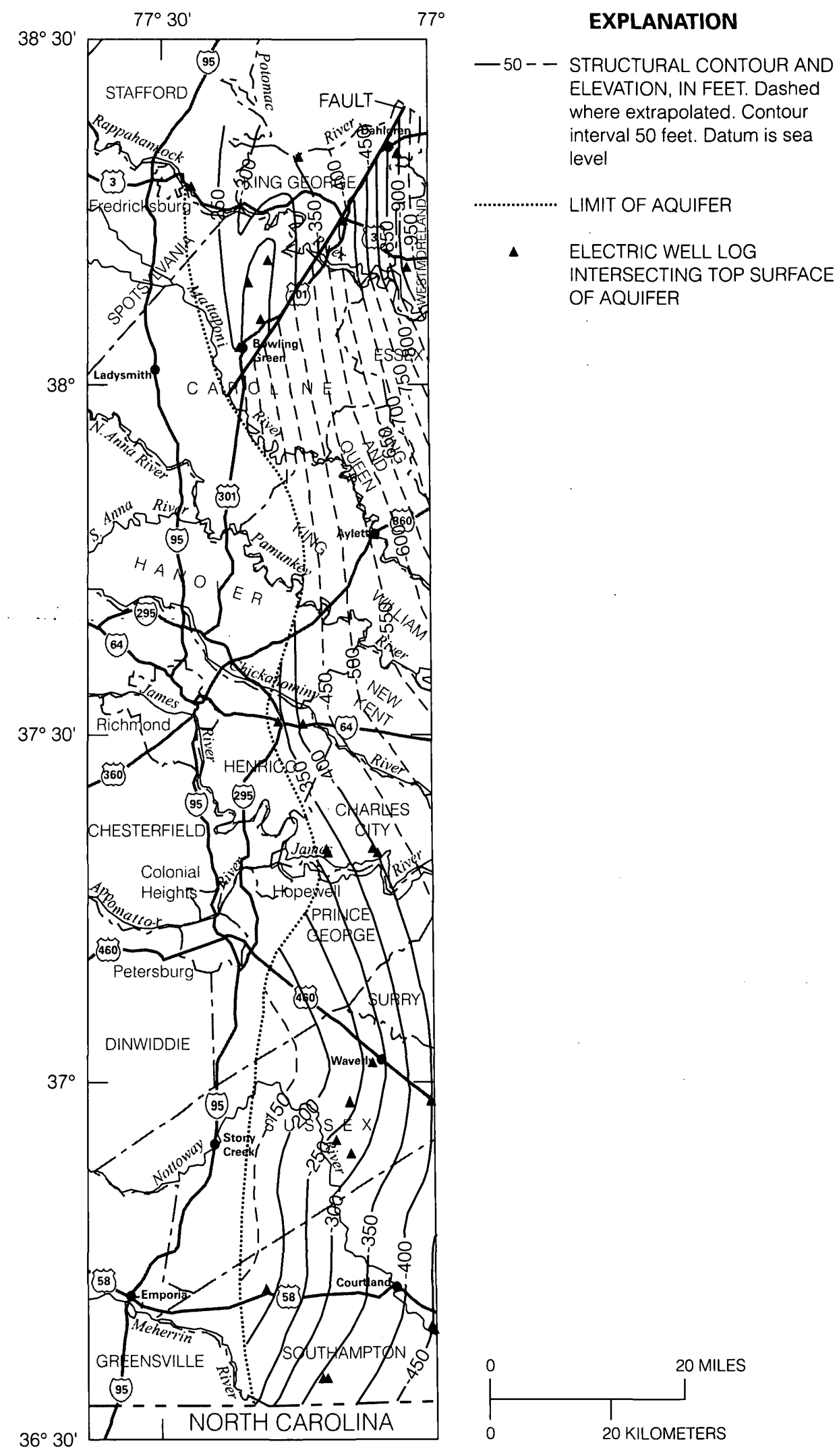

- ELECTRIC WELL LOG

INTERSECTING TOP SURFACE OF AQUIFER

Figure 19. Top surface elevation of the lower Potomac aquifer in the Fall Zone of Virginia. 

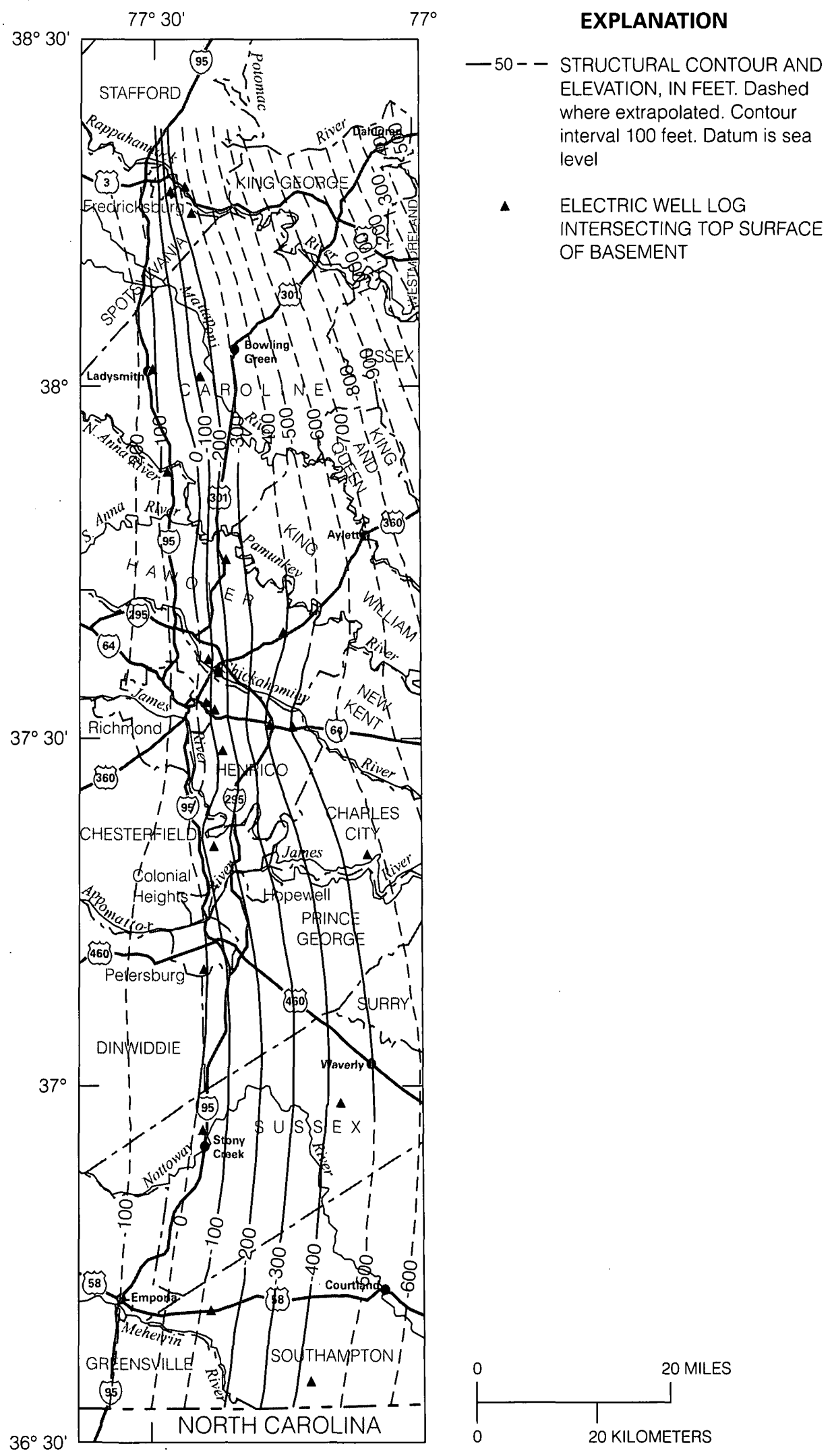

- Electric WelL LOG

INTERSECTING TOP SURFACE OF BASEMENT

Figure 20. Top surface elevation of the basement in the Fall Zone of Virginia. 
Choptank Formations also potentially make up part of the Calvert confining unit in some areas (fig. 21), although the presence of the latter two formations within the Fall Zone is uncertain. The geologic log of well 54L 10 indicates that the interval designated as the Chickahominy-Piney Point aquifer is composed of sediments belonging to the Old Church Formation. The stratigraphically lower Chickahominy and Piney Point Formations also potentially make up part of the Chickahominy-Piney Point aquifer in some areas (fig. 21), although their presence within the Fall Zone is uncertain.

From an elevation of greater than $120 \mathrm{ft}$ near its western limit, the top of the Calvert confining unit dips eastward to below $30 \mathrm{ft}$ (fig. 10). Similarly, from an elevation of greater than $60 \mathrm{ft}$ near its western limit, the top of the Chickahominy-Piney Point aquifer dips eastward to below - $20 \mathrm{ft}$ (fig. 11). All of the major rivers that traverse the area spanned by the Calvert confining unit and Chickahominy-Piney Point aquifer are incised through the entire thickness of the confining unit and into the aquifer, resulting in extensive aquifer subcrop areas that likely extend farther east along the rivers.

The vertical positions of the ChickahominyPiney Point aquifer and Calvert confining unit generally correspond to those delineated by previous studies (Meng and Harsh, 1988; Harsh and Laczniak, 1990; Hamilton and Larson, 1988; Laczniak and Meng, 1988). By contrast, the areal extents delineated in this study are less broad and are constrained farther to the east by several miles. The Calvert confining unit was delineated to extend only as far as the directly underlying Chickahominy-Piney Point aquifer. The Chickahominy-Piney Point aquifer was delineated farther west by the previous studies on the basis of vertical intervals on electric logs that indicate relatively high porosities and permeabilities. Lithologic descriptions and geologic logs, however, indicate that porous and permeable sediments that are hydraulically contiguous with either the Chickahominy or the Piney Point Formations do not extend as far west as delineated by the previous studies. The electric log intervals possibly result from high shell contents, combined with fine-grained sediments, that falsely indicate relatively high permeabilities.

\section{Aquia Aquifer and Nanjemoy-Marlboro Confining Unit}

Intervals were identified on 90 electric logs and 4 geologic logs that were designated to represent the Aquia aquifer, and on 83 electric logs and 5 geologic logs that were designated to represent the overlying Nanjemoy-Marlboro confining unit (app. 1). The logs are of wells located throughout most of the Fall Zone except the southwestern part (figs. 12 and 13). Lithologic descriptions corresponding to both of these intervals indicate that the sediments are primarily of marine origin, consisting generally of glauconitic, partly shelly, and poorly sorted sand with varying amounts of silt and clay, but that the lower part of the sediments at some locations is of fluvial and (or) deltaic origin, consisting generally of medium-tocoarse-grained sand with varying amounts of gravel, silt, and clay.

The geologic logs (app. 2) indicate that the interval designated as the Nanjemoy-Marlboro confining unit is composed of fine-grained sediments, most of which belong to the Nanjemoy Formation but which also include the stratigraphically higher Eastover and Calvert Formations at some locations. The stratigraphically higher Saint Marys Formation and the stratigraphically lower Marlboro (possibly present at well 53M 1) and Aquia Formations also potentially make up part of the Nanjemoy-Marlboro confining unit in some areas (figs. 21 and 22). The presence of the Saint Marys Formation within the Fall Zone is uncertain, however, and the Marlboro Formation is constrained to the northern Fall Zone whereas the Aquia Formation is constrained to the northern and southeastern Fall Zone.

The geologic logs (app. 2) indicate that the interval designated as the Aquia aquifer is composed of medium-to-coarse-grained sediments that at some locations belong to the Aquia Formation but that at other locations belong wholly or in part to the stratigraphically higher Eastover Formation (fig. 22) and the stratigraphically lower Potomac Formation (fig. 21). Permeable sediments within both the Eastover and Aquia Formations include medium-to-coarsegrained glauconitic sand with varying amounts of shell, gravel, silt, and clay, whereas permeable sediments within the Potomac Formation include medium-tocoarse-grained quartz sand with varying amounts of gravel, silt, and clay. At some locations, permeable sediments belonging to the Aquia Formation directly 


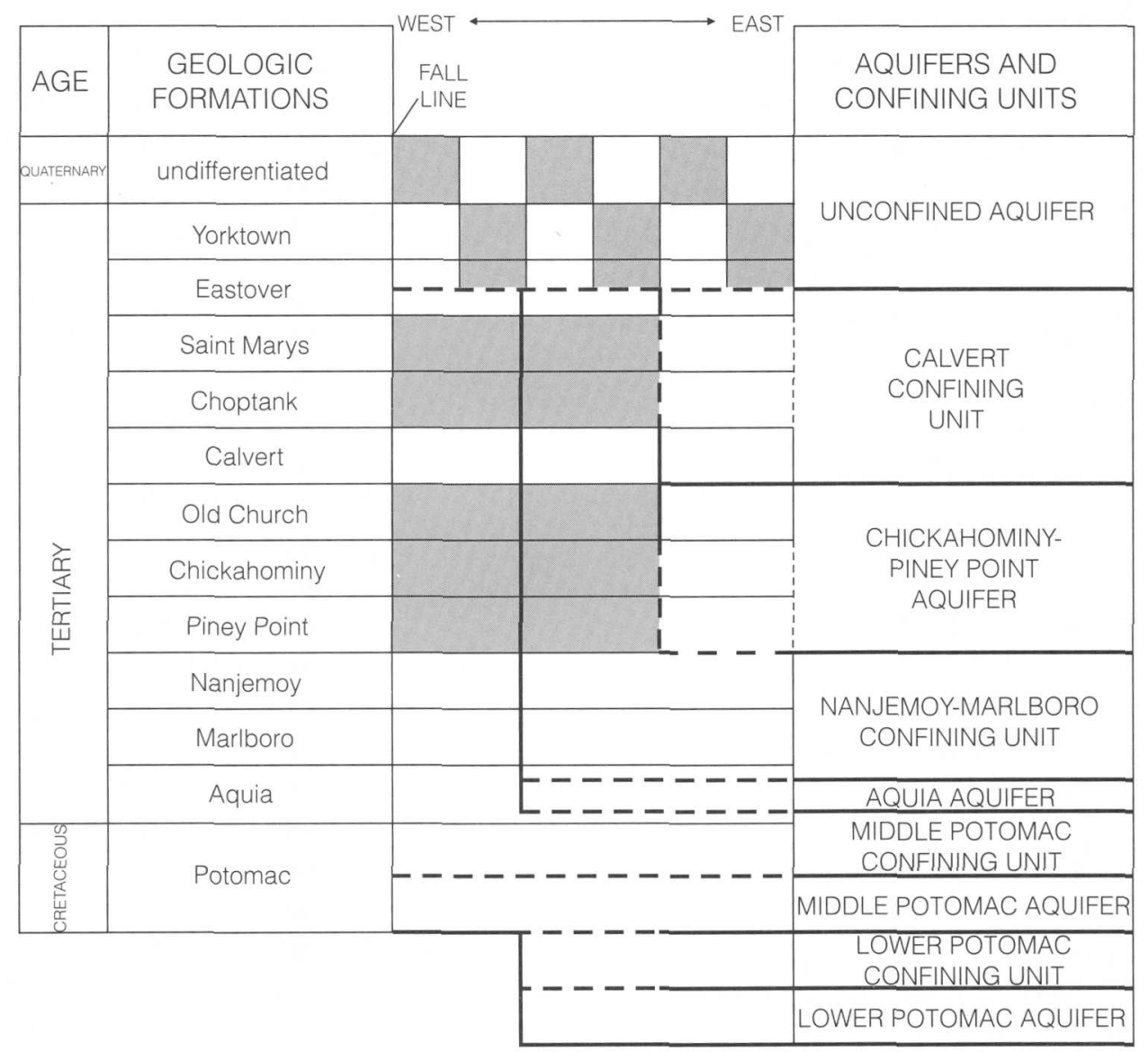

Figure 21. Summary of relations among geologic formations and aquifers and confining units in the northern Fall Zone of Virginia. Horizontal dashed lines indicate where positions of aquifer-confining unit contacts are variable. Vertical dashed lines indicate where presence of geologic formations is uncertain. Shaded areas indicate where geologic formations are not present. Vertical spacing does not indicate sediment thickness. 


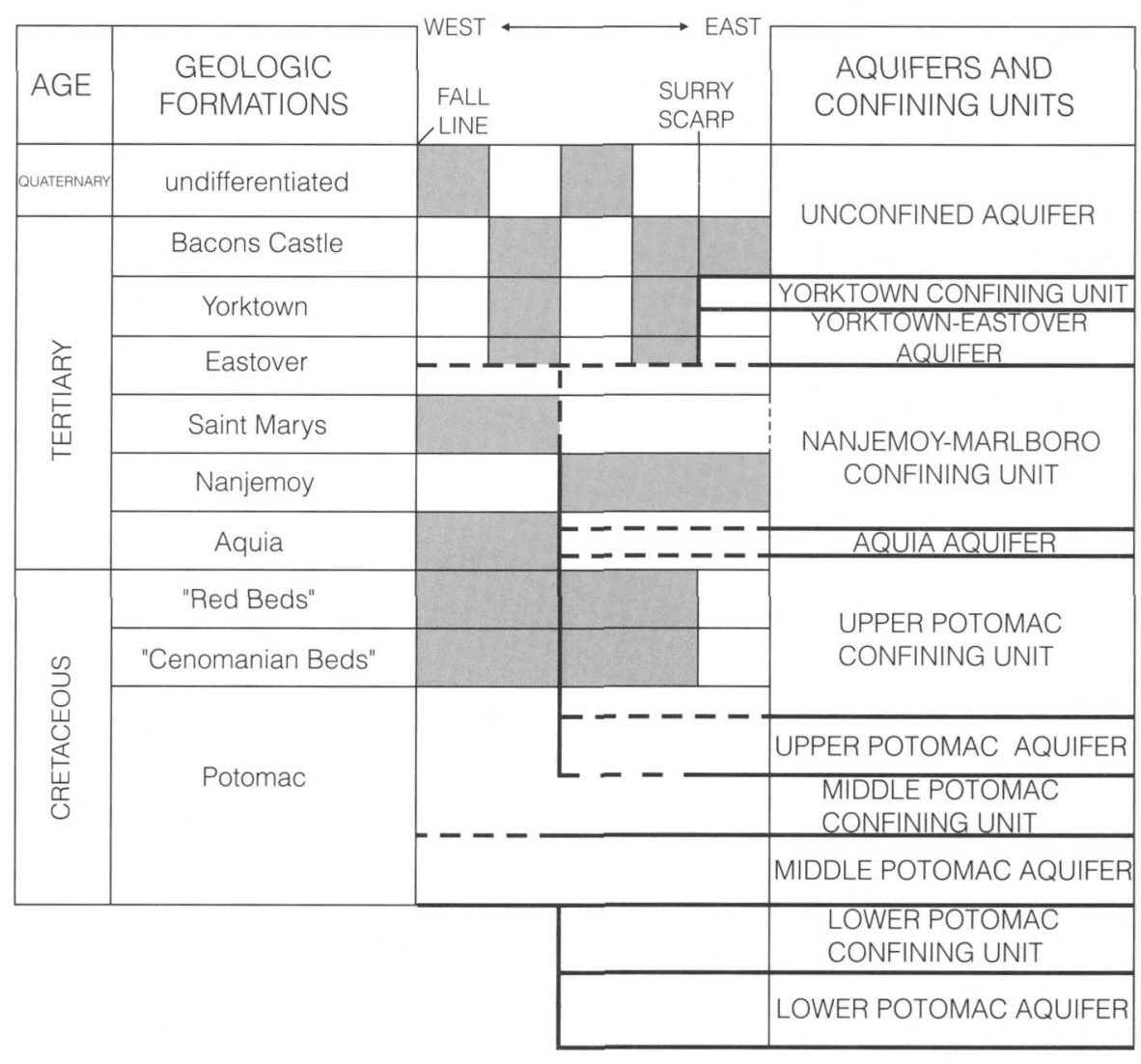

Figure 22. Summary of relations among geologic formations and aquifers and confining units in the southern Fall Zone of Virginia. Horizontal dashed lines indicate where positions of aquifer-confining unit contacts are variable. Vertical dashed lines indicate where presence of geologic formations is uncertain. Shaded areas indicate where geologic formations are not present. Vertical spacing does not indicate sediment thickness. 
overlie those of the Potomac Formation (without any intervening fine-grained sediments), and the sediments of both formations function hydraulically as a single aquifer designated as the Aquia. At other locations, only permeable sediments belonging to the Potomac Formation are present but, based on elevation and lateral continuity, are theorized to be hydraulically contiguous with and to function as part of the Aquia aquifer.

From an elevation as great as $160 \mathrm{ft}$ near its western limit, the top of the Nanjemoy-Marlboro confining unit dips eastward to below -50 ft (fig. 12). Similarly, from an elevation of greater than $70 \mathrm{ft}$ near its western limit, the top of the Aquia aquifer dips eastward to $-160 \mathrm{ft}$ (fig. 13). Additionally in the northern Fall Zone, aquifer elevation offsets and dip reversals were observed to be consistent with structural mapping by Mixon and others (1988) that delineates complex folding and faulting. Accordingly, these features were interpreted to be exhibited by the top of the Aquia aquifer. The same structures likely extend upward internally through the Nanjemoy-Marlboro confining unit. The top of the confining unit, however, was eroded prior to deposition of the present-day surficial deposits (see section "Unconfined Aquifer"), and the structures are not exhibited by the top of the Nanjemoy-Marlboro confining unit. The Potomac, Rappahannock, James, and Nottoway Rivers are incised partway through the Nanjemoy-Marlboro confining unit and into the Aquia aquifer, resulting in aquifer subcrop areas along parts of those rivers. The Mattaponi, Pamunkey, and Chickahominy Rivers are positioned relatively higher and, consequently, are incised only partly into the confining unit, so aquifer subcrop areas are not present.

Both the vertical positions and areal extents of the Aquia aquifer and Nanjemoy-Marlboro confining unit generally correspond to those delineated by previous studies (Meng and Harsh, 1988; Harsh and Laczniak, 1990; Hamilton and Larson, 1988; Laczniak and Meng, 1988). In the northern Fall Zone (except near the James River), both the aquifer and confining unit extend nearly to the Fall Line: Coastal Plain sediments that extend farther west consist primarily of caps overlying saprolite and bedrock (see section "Unconfined Aquifer"). Aquifer outcrop areas delineated by Laczniak and Meng (1988), however, differ from subcrop areas delineated in this study. In the southern Fall Zone, the aquifer and confining unit do not extend as far west as the Fall Line, but were extrapolated by the previous studies beyond well locations and slightly farther west than by this study. Sediments that compose the aquifer and confining unit in the southern Fall Zone possibly were not deposited as far west as the Fall Line. Alternatively, faulting near Hopewell (Dischinger, 1987) is theorized to extend into the southern Fall Zone (Mixon and others, 1989), along which the sediments that compose the aquifer and confining unit possibly pinch out or are truncated.

\section{Upper Potomac Aquifer and Upper Potomac Confining Unit}

Intervals were identified on 39 electric logs that were designated to represent the upper Potomac aquifer, and on $32 \operatorname{logs}$ and 1 geologic log that were designated to represent the overlying upper Potomac confining unit (app. 1). The logs are of wells located entirely in the southeastern part of the Fall Zone (figs. 14 and 15). Lithologic descriptions corresponding to both intervals indicate that the sediments at some locations are of marine origin, consisting generally of glauconitic, partly shelly, poorly sorted sand with varying amounts of silt and clay, but at other locations are of fluvial and (or) deltaic origin, consisting generally of medium-to-coarse grained sand with varying amounts of gravel, silt, and clay.

The geologic log of well 53B 6 (app. 2) indicates that the interval designated as the upper Potomac confining unit is composed of fine-grained sediments belonging to the "Red beds" of Powars and others (1988). Their "Cenomanian beds," the stratigraphically lower Potomac Formation, and the stratigraphically higher Aquia Formation, also potentially make up part of the upper Potomac confining unit in some areas (fig. 22). Sediments within the Aquia Formation and Cenomanian Beds include fine-grained glauconitic sand with varying amounts of shell, gravel, silt, and clay, whereas sediments within the Red Beds and Potomac Formation include clay and silt with varying amounts of sand and gravel. Based on elevation and lateral continuity, the interval is theorized to be hydraulically contiguous and to function as a single confining unit.

Lithologic descriptions indicate that the interval designated as the upper Potomac aquifer is composed of sediments which at some locations possibly belong to the Aquia Formation, but which at other locations belong wholly or in part to the stratigraphically lower 
Potomac Formation (fig. 22). Permeable sediments within the Aquia Formations include medium-grained glauconitic sand with varying amounts of shell, silt, and clay, whereas those within the Potomac Formation include medium-to-coarse-grained quartz sand with varying amounts of gravel, silt, and clay. The interval is distinct from and at a lower elevation than the interval designated as the Aquia aquifer. Cenomanian Beds and Red Beds that separate the Aquia Formation from the Potomac Formation in areas farther east (Powars and others, 1988) apparently pinch out toward the west. Based on elevation and lateral continuity, sediments within the interval designated as the upper Potomac aquifer are theorized to be hydraulically contiguous and to function as a single aquifer.

Harsh and Laczniak (1990) used "Brightseatupper Potomac" to refer to both the aquifer and the confining unit. Because the Brightseat formation was not identified within the Fall Zone, the term "upper Potomac" is used in this study.

From an elevation of approximately $100 \mathrm{ft}$ near its western limit, the top of the upper Potomac confining unit dips eastward to $-130 \mathrm{ft}$ (fig. 14). Similarly, from an elevation of greater than $50 \mathrm{ft}$ near its western limit, the top of the upper Potomac aquifer dips eastward to below -150 ft (fig. 15). The Meherrin River and two nearby tributaries are incised partway through the upper Potomac confining unit and into the upper Potomac aquifer, resulting in aquifer subcrop areas along parts of those streams. The Nottoway River is positioned higher and, consequently, is incised only partly into the confining unit, so an aquifer subcrop area is not present.

The vertical positions of the upper Potomac aquifer and upper Potomac confining unit generally correspond to those delineated by previous studies (Meng and Harsh, 1988; Harsh and Laczniak, 1990; Hamilton and Larson, 1988; Laczniak and Meng, 1988). By contrast, the areal extents in the previous studies are constrained slightly farther east in the southern Fall Zone but span farther into the northern Fall Zone, in some cases extrapolated as much as $20 \mathrm{mi}$ or more beyond well locations. On the basis of elevation and lateral continuity, permeable sediments within the northern Fall Zone are theorized in this study to be hydraulically contiguous with aquifers other than the upper Potomac aquifer.

\section{Middle Potomac Aquifer and Middle Potomac Confining Unit}

Intervals were identified on 114 electric logs and 5 geologic $\log$ that were designated to represent the middle Potomac aquifer, and on 114 electric logs and 3 geologic logs that were designated to represent the overlying middle Potomac confining unit (app. 1). The logs are of wells located throughout the Fall Zone (figs. 16 and 17). Lithologic descriptions corresponding to the interval designated to represent the middle Potomac confining unit indicate that the sediments at some locations are of fluvial and (or) deltaic origin, consisting generally of clay and silt with varying amounts of sand and gravel, but at other locations are of marine origin, consisting generally of glauconitic, partly shelly, fine-grained sand, silt, and clay.

Lithologic descriptions corresponding to the interval designated to represent the middle Potomac aquifer indicate that the sediments are entirely of fluvial and (or) deltaic origin, consisting generally of medium-tocoarse-grained sand with varying amounts of gravel, silt, and clay.

The geologic logs (app. 2) indicate that the interval designated as the middle Potomac confining unit is composed of fine-grained sediments belonging to the Nanjemoy Formation at well 52E 2 and to the Aquia Formation at wells 52G 24 and 52G 26. Lithologic descriptions from other locations indicate that the interval is composed of sediments that at some locations possibly belong to the Nanjemoy and (or) Aquia Formations but that at other locations potentially include the stratigraphically higher Eastover and Calvert Formations, the intervening Marlboro Formation, and the stratigraphically lower Potomac Formation (figs. 21 and 22). Sediments within all but the Potomac Formation include fine-grained glauconitic sand with varying amounts of shell, gravel, silt, and clay. Sediments within the Potomac Formation include clay and silt with varying amounts of sand and gravel. Based on elevation and lateral continuity, the interval is theorized to be hydraulically contiguous and to function as a single confining unit.

The geologic logs (app. 2) along with lithologic descriptions from other locations indicate that the interval designated as the middle Potomac aquifer is composed entirely of sediments belonging to the Potomac Formation (figs. 21 and 22). Permeable 
sediments within the Potomac Formation include medium-to-coarse-grainéd quartz sand with varying amounts of gravel, silt, and clay.

Within the Potomac Formation, sediments that compose the middle Potomac confining unit are distinguished from those composing the middle Potomac aquifer primarily by having a greater proportion of fine-grained materials. Predominantly marine sediments that overlie the Potomac Formation were deposited in stable widespread environments and, consequently, have areally uniform lithologic compositions that span large areas. By contrast, the predominantly fluvial and deltaic sediments of the Potomac Formation were deposited in dynamic localized environments and, consequently, have variable lithologic compositions that are areally discontinuous. Gravel, sand, silt, and clay mixed in various proportions are present in highly interbedded strata in which individual beds span distances as short as a few hundred feet or less. Hence, designation of intervals within the Potomac Formation representing either confining units or aquifers that span distances of tens of miles is subjective. Intervals can be identified, however, that likely consist of zones in which clay-rich beds (in the case of confining units) or sand-rich beds (in the case of aquifers) are relatively concentrated.

From an elevation of nearly $150 \mathrm{ft}$ near its western limit, the top of the middle Potomac confining unit dips eastward to nearly $-300 \mathrm{ft}$ (fig. 16). Similarly, from an elevation of nearly $100 \mathrm{ft}$ near its western limit, the top of the middle Potomac aquifer dips eastward to below $-320 \mathrm{ft}$ (fig. 17). Additionally in the northern Fall Zone, confining unit and aquifer elevation offsets and dip reversals were observed to be consistent with structural mapping by Mixon and others (1988) that delineates complex folding and faulting. Accordingly, these features were interpreted to be exhibited by the tops of the middle Potomac confining unit and aquifer. Elevation offsets also are apparent at a few locations near the James River (McFarland, 1997), possibly associated with the Hopewell-Dutch Gap fault (Dischinger, 1987), but are of small magnitude and limited areal extent. The James, Nottoway, and Meherrin Rivers, as well as a nearby tributary, are incised partway through the middle Potomac confining unit and into the middle Potomac aquifer, resulting in aquifer subcrop areas along parts of those streams. The geologic logs of wells 52G 29 and 52H 15 (app. 2) indicate surficial lowland deposits directly overlying the Potomac aquifer near the James River. The
Potomac, Rappahannock, Mattaponi, Pamunkey, and Chickahominy Rivers are positioned relatively higher and, consequently, neither the confining unit nor the aquifer is incised.

The vertical positions of the middle Potomac aquifer and confining unit generally correspond to those delineated by previous studies (Meng and Harsh, 1988; Hamilton and Larson, 1988; Laczniak and Meng, 1988; Harsh and Laczniak, 1990). By contrast, the areal extents in the previous studies were extrapolated farther west by several miles. In this study, both the aquifer and confining unit were considered to extend nearly to the Fall Line. Potomac Formation sediments that extend farther west, however, compose the base of caps overlying saprolite and bedrock (see section "Unconfined Aquifer") and were excluded.

\section{Lower Potomac Aquifer and Lower Potomac Confining Unit}

Intervals were identified on 27 electric logs that were designated to represent the lower Potomac aquifer and on 29 electric logs that were designated to represent the overlying lower Potomac confining unit (app. 1). The logs are of wells located throughout the Fall Zone (figs. 18 and 19). Lithologic descriptions corresponding to both intervals indicate that the sediments are entirely of fluvial and (or) deltaic origin, consisting generally of medium-to-coarse-grained sand with varying amounts of gravel, silt, and clay belonging to the Potomac Formation (figs. 21 and 22).

As with the middle Potomac aquifer and confining unit, sediments that compose the lower Potomac confining unit are distinguished from those composing the lower Potomac aquifer primarily by having a greater proportion of fine-grained materials. Based on elevation and lateral continuity, the interval that represents the lower Potomac confining unit likely consists of a zone of relatively concentrated clay-rich beds, and the interval that represents the lower Potomac aquifer likely consists of a zone of relatively

concentrated sand-rich beds.

From an elevation of greater than $-150 \mathrm{ft}$ near its western limit, the top of the lower Potomac confining unit dips eastward and northeastward to nearly $-800 \mathrm{ft}$ (fig. 18). Similarly, from an elevation of greater than $2000 \mathrm{ft}$ near its western limit, the top of the lower Potomac aquifer dips eastward and northeastward to nearly $-950 \mathrm{ft}$ (fig. 19). Additionally in the northern 
Fall Zone, confining unit and aquifer elevation offsets and dip reversals were observed to be consistent with structural mapping by Mixon and others (1988) that delineates complex folding and faulting. Accordingly, these features were interpreted to be exhibited by the tops of the lower Potomac confining unit and aquifer. Because of the relatively great depth of both the aquifer and confining unit, neither the aquifer nor the confining unit is incised by any rivers.

The vertical positions of the lower Potomac aquifer and confining unit generally correspond to those delineated by previous studies (Meng and Harsh, 1988; Hamilton and Larson, 1988; Laczniak and Meng, 1988; Harsh and Laczniak, 1990). By contrast, the areal extents in the previous studies generally were extrapolated farther west by several miles. As with the middle Potomac aquifer and confining unit, gravel, sand, silt, and clay are mixed in various proportions in discontinuous and highly interbedded strata, and designation of intervals within the Potomac Formation that represent either confining units or aquifers is subjective.

\section{Basement}

Intervals were identified on 23 electric logs that were designated to represent basement bedrock (app. 1). The logs are of wells located throughout most of the Fall Zone (fig. 20), except the northeastern part where the basement surface was inferred from Brown and others (1972). Most electric logs terminate near the basement surface. Lithologic descriptions indicate that bedrock at most locations consists of crystalline (either igneous or metamorphic) rock, but at a few locations consists of sedimentary rock.

The most widespread rocks in the Piedmont next to the Fall Line in Virginia include porphyroblastic garnet-biotite gneiss along the northern part, Petersburg granite along the central part, and mafic and felsic volcanics intruded by granite along the southern part (Virginia Division of Mineral Resources, 1993). In addition, sedimentary rocks are present within a Triassic-age structural basin located approximately 20 mi north of Richmond. Piedmont rocks along the Fall Line extend eastward for an unknown distance beneath the Coastal Plain sediments, where other rock types also possibly are present.
From an elevation of nearly $150 \mathrm{ft}$ near the Fall Line, the basement surface dips eastward and northeastward to $-1500 \mathrm{ft}$ (fig. 20). The dip angle is nearly twice as steep as that of the overlying Coastal Plain sediments (figs. 8-19). Numerous elevation offsets on the basement surface possibly are present as a result of faulting but cannot be inferred from the available data. The vertical position of the basement surface generally corresponds to that delineated by Meng and Harsh (1988) but was not delineated by the other previous studies (Hamilton and Larson, 1988; Laczniak and Meng, 1988; Harsh and Laczniak, 1990). The basement surface extends areally beyond the Fall Zone, westward into the Piedmont and eastward at depth beneath the Coastal Plain sediments (fig. 2).

\section{GROUND-WATER FLOW}

Ground water in the Fall Zone is recharged at the water table, flows through the unconfined aquifer to discharge to nearby streams, and leaks downward to recharge confined aquifers. Recharge varies seasonally and annually in response to climatic changes. Flow through confined aquifers is in the regionally downgradient direction toward the east but also locally directed toward discharge along major rivers where confined aquifers and confining units are incised by the rivers and overlain by floodplain and terrace deposits.

Volumetric rates calculated by local-scale ground-water-flow models constructed within the Fall Zone indicate that, of an estimated $10 \mathrm{in} / \mathrm{yr}$ of recharge at the water table, greater than $9 \mathrm{in} / \mathrm{yr}$ discharges locally to rivers and streams and less than $1 \mathrm{in} / \mathrm{yr}$ provides recharge to the regional flow system. Where confined aquifer subcrop areas are present along major rivers, approximately $2 \mathrm{in} / \mathrm{yr}$ is exchanged locally between the unconfined and confined parts of the flow system.

Near-surface relations between the unconfined and confined flow systems within the Fall Zone are similar to those in other parts of the Virginia Coastal Plain. Previous ground-water-flow modeling of the entire Virginia Coastal Plain indicated that, as a result of large withdrawals at locations east of the Fall Zone, areas and rates of downward leakage and regional recharge to confined aquifers have increased throughout the Virginia Coastal Plain. Although the Fall Zone was possibly a significant source of regional recharge prior to the large withdrawals, greater rates of 
regional recharge potentially have resulted from large drawdowns near major pumping centers located farther east.

\section{Description of the Ground-Water-Flow System}

Harsh and Laczniak (1990) presented a conceptual model of ground-water flow in the Virginia Coastal Plain. Ground water is recharged principally by infiltration of precipitation and percolation to the water table. As is characteristic in the humid temperate climate of the eastern United States, the water table is relatively shallow (generally less than $50 \mathrm{ft}$ below land surface), and it is subparallel to the land surface. Following the water-table slope, most of the unconfined ground water flows relatively short distances and discharges to nearby gaining streams, thereby maintaining baseflow. A smaller amount of ground water flows from the unconfined aquifer downward through the underlying confining unit to recharge deeper confined aquifers (fig. 2). Digital model analysis of the entire Coastal Plain aquifer system in Virginia (Harsh and Laczniak, 1990) indicated that recharge to the confined aquifers primarily is along the Fall Zone and beneath surfacedrainage divides between major river valleys. Flow through the confined aquifers primarily is lateral in the down-dip direction to the east and toward large withdrawal centers and major discharge areas near large rivers and the Atlantic Coast (fig. 2). Dense saline water at the interface between freshwater and saltwater causes the confined ground water to discharge by upward flow across intervening confining units.

During this study, water levels in wells were examined to determine distributions of hydraulic head and thereby to infer hydraulic gradients and directions of ground-water flow throughout the Fall Zone in only the confined aquifers. Hydraulic head within the unconfined aquifer is represented by the water table, which was delineated across a local-scale area surrounding the James River (McFarland, 1997) but was not delineated at the same level of detail throughout the Fall Zone. As was found near the James River and thus extended in concept for the entire Virginia Coastal Plain (Harsh and Laczniak, 1990), the water table throughout the Fall Zone likely is subparallel to the land surface: the highest elevations of the water table are in the uplands, where ground water is recharged, and the lowest elevations are in the lowlands, where ground water is discharged and thereby maintains baseflow in gaining streams. Estimates of the position of the water table from several sources (McFarland, 1997; T.S. Bruce, Virginia Department of Environmental Quality, written commun., 1997; G.K. Speiran, U.S. Geological Survey, written commun., 1997) indicate the water table to be as much as $30 \mathrm{ft}$ or more below land surface in some uplands, but virtually at the land surface in lowlands near streams, and to fluctuate seasonally by several feet or more in response to variations in recharge rates.

Water levels were measured in the Fall Zone from August 1995 through September 1998 in observation wells constructed in confined aquifers as part of this study (figs. 6 and 23). All measurements were made "synoptically"--within a period of one to two days during which no significant recharge occurred. Water levels measured during 1995-96 in observation wells located near the James River during the initial phase of the study are documented by McFarland (1997). Of these, instantaneous measurements in the five wells that are open to confined aquifers are included in this report (additional wells open to the unconfined aquifer are not included). Water levels in well 52H 17 in the Aquia aquifer and wells 52G 24 and 52H 15 in the middle Potomac aquifer continued to be measured during the second phase of the study during 1997-98 (fig. 23). Measurements in wells 52G 26 and 52G 29 in the middle Potomac aquifer, however, were discontinued after the initial phase.

Water levels also were measured synoptically in six additional observation wells constructed during the second phase of the study: well 54L 10 in the Chickahominy-Piney Point aquifer, wells 51M 18, 53B 6, 53B 7, and 53M 1 in the Aquia aquifer, and well 52E 2 in the middle Potomac aquifer (fig. 23). Water levels also were measured in an existing unused water-supply well, 52L 9, in the Aquia aquifer.

All of the water levels exhibit fluctuations, ranging from approximately $1 \mathrm{ft}$ in some wells to nearly $10 \mathrm{ft}$ in other wells (fig. 23). Fluctuations in most of the wells are probably in response to seasonal changes in recharge (McFarland, 1997). Recharge typically begins in late fall to early winter and continues into spring, when rates of infiltration exceed rates of evapotranspiration. Water percolates downward to the water table, which is elevated as a result. In response, downward leakage from the unconfined 
aquifer to the uppermost confined aquifer increases, thereby increasing recharge to, and hydraulic head in, the confined aquifer. As air temperature and plant growth increase in the spring, evapotranspiration exceeds infiltration and recharge ceases. Both the water table and hydraulic head in the confined aquifer decline as ground water flows out of the aquifers in downgradient directions toward discharge areas.

All of the wells are open to the uppermost confined aquifer at each well location and, except for wells 52G 26 and 52G 29, indicate seasonal recharge, exhibiting the lowest water levels in late fall to early winter and the highest water levels in mid-to-late spring (fig. 23). Different ranges of water-level fluctuation among the wells possibly result from different amounts of recharge at well locations. Wells 52G 26 and 52G 29 are near the James River, where tides range as much as several feet (McFarland, 1997) and along which subcrop areas of the middle Potomac aquifer are present (fig. 17). Continuous water-level and tidal-stage measurements indicate that water levels in wells 52G 26 and 52G 29 are hydraulically controlled primarily by tidal fluctuations of the James River (McFarland, 1997).

The range of water-level fluctuation also is inversely proportional to the specific storage of the aquifer sediment. Specific storage is a function of the physical properties of the sediment, including its porosity and compressibility (Freeze and Cherry, 1979). Given the same amount of recharge, sediment having a small specific storage exhibits a larger waterlevel fluctuation range than sediment having a large specific storage. Among the wells indicating seasonal recharge, those open to fluvial and deltaic sediments of the Potomac Formation exhibit generally larger fluctuation ranges than those open to the marine sediments of other formations. Assuming equal recharge amounts at all locations, Potomac Formation sediments possibly have a smaller specific storage than the marine sediments.

In order to determine distributions of hydraulic head in the confined aquifers, water levels measured in observation wells constructed as part of this study were examined, along with available water-level data from 33 statewide water-level observation network wells located in the Fall Zone (fig. 6) and from additional statewide network wells located farther east (White and Powell, 1997). The areal distributions of approximate water-level elevations calculated for each well (see section "Methods of Investigation") were plotted and contoured where possible to estimate the potentiometric surfaces of the Chickahominy-Piney Point, Aquia, upper Potomac, middle Potomac, and lower Potomac aquifers (figs. 24-27). No water-level measurements are available from the small area occupied by the confined part of the YorktownEastover aquifer in the southeastern Fall Zone (see section "Hydrogeologic Framework").

Water levels have been measured in only one well in the Chickahominy-Piney Point aquifer within the Fall Zone (well 54L 10 constructed as part of this study) at elevations of approximately $43 \mathrm{ft}$ (figs. 23 and 24). Water levels in other wells in the ChickahominyPiney Point aquifer located $30 \mathrm{mi}$ or more farther southeast of the Fall Zone are several tens of feet lower (White and Powell, 1997), indicating a regional component of flow toward the southeast. Within the Fall Zone, however, the Chickahominy-Piney Point aquifer is extensively incised by major rivers and associated floodplain and terrace deposits (see section "Hydrogeologic Framework"). Flow is directed locally toward discharge along the rivers, and the potentiometric surface probably is intricately configured around aquifer subcrop areas.

Water levels have been measured in several wells in the Aquia aquifer, most within the central and northern parts of the Fall Zone (fig. 24). These and additional water levels for the same aquifer in wells located several miles farther east (White and Powell, 1997) indicate a regional component of flow toward the east. The Aquia aquifer along with the directly overlying Nanjemoy-Marlboro confining unit is incised by major rivers and associated floodplain and terrace deposits in the Fall Zone. Flow is directed locally toward discharge along the rivers, and the potentiometric surface probably is intricately configured around aquifer subcrop areas and additional areas where the overlying confining unit is thin.

Water levels have been measured relatively extensively in wells in the upper Potomac, middle Potomac, and lower Potomac aquifers throughout the Fall Zone (figs. 25-27). These and additional water levels for the same aquifers in wells located several miles farther east (White and Powell, 1997) indicate regional components of flow to the east in all three aquifers. Data are lacking, however, for the middle Potomac aquifer in the northern part of the Fall Zone (fig. 26) and for the lower Potomac aquifer in the central and southern parts (fig. 27) and potentiometric surfaces can be only estimated in these areas. Similarly, 

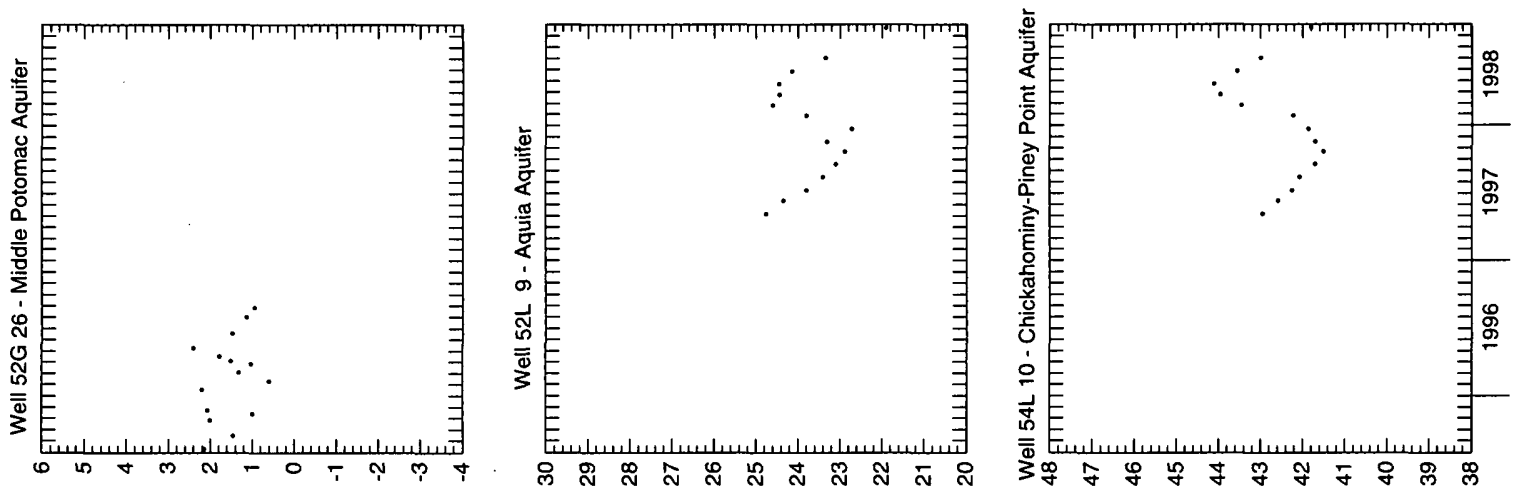

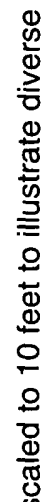
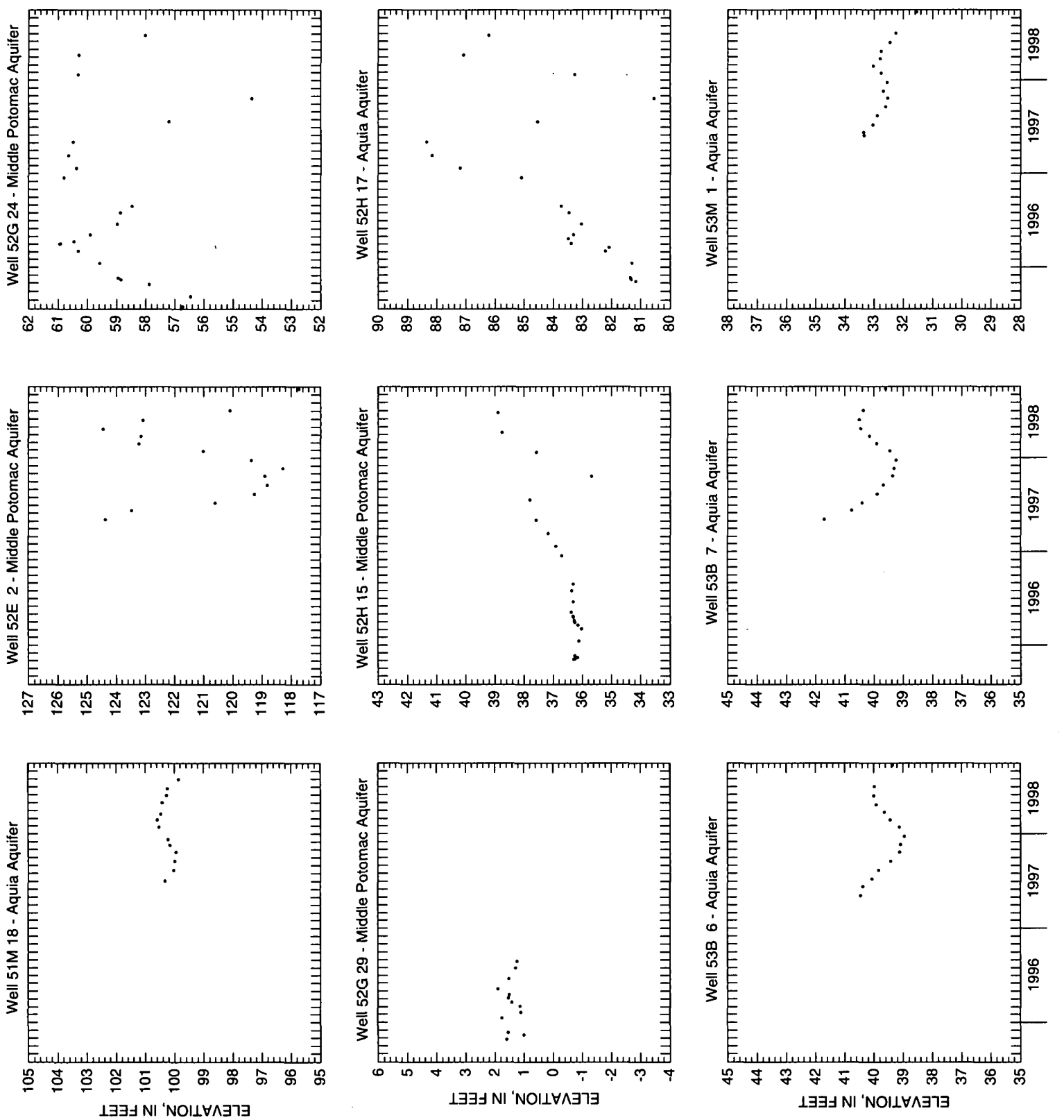
the potentiometric surfaces of the upper Potomac and middle Potomac aquifers are approximated as being configured around aquifer subcrop areas, where flow is directed locally toward discharge along major rivers (figs. 25 and 26).

Vertical gradients between adjacent aquifers generally are downward, based on comparisons of different water levels among the aquifers at specific locations and of the potentiometric surfaces where contoured. The magnitudes of water-level differences are variable, however, ranging from near zero at some locations to several tens of feet at other locations. In addition, a water-level difference of several tenths of a foot is consistently exhibited between wells 53B 6 and 53B 7 (fig. 23), both in the Aquia aquifer, indicating a small but persistent downward gradient within the aquifer at that location.

Vertical gradients between and within aquifers can vary spatially in magnitude and direction. During the initial phase of the study, vertical gradients in proximity to the James River were found to vary greatly in magnitude and direction over relatively short distances, as a result of locally directed flow toward discharge along the river (McFarland, 1997). Similar conditions probably exist within localized areas along the other major rivers.

The largest downward gradient observed is between well 52H 17 in the Aquia aquifer (fig. 3, table 1) with a water-level elevation of approximately $85 \mathrm{ft}$ (fig. 24) and several nearby wells in the middle Potomac aquifer (fig. 26) with water-level elevations as low as $-46 \mathrm{ft}$. The middle Potomac aquifer in the Fall Zone is a locally significant source of water for Hanover and Henrico Counties. Available data are not adequate, however, to determine whether withdrawal has increased the vertical gradient with, and hence downward leakage from, the Aquia aquifer.

There are also not enough data to characterize vertical flow between the Coastal Plain sediments and underlying bedrock on a regional scale across the entire Fall Zone. Conditions observed at some locations indicate that ground water is discharged from bedrock into Coastal Plain sediments. Relatively large upward vertical gradients have been found in the Fall Zone between wells open to bedrock and nearby wells open to Coastal Plain sediments (A.A. Meng, III, oral commun., 1998). In addition, radionuclides found at high concentration in water in some wells open to Coastal Plain sediments possibly originate from mineralized zones in bedrock (D.L. Nelms, U.S.
Geological Survey, oral commun., 1998), although phosphate minerals within the sediments that are enriched with radionuclides are another possible source.

Throughout the Piedmont, ground water is present in bedrock fractures, some of which possibly extend beneath Coastal Plain sediments (fig. 2). Most ground-water flow in the Piedmont, however, takes place at depths within $30 \mathrm{ft}$ below land surface, commonly along high-permeability zones between weathered residuum or saprolite and shallow bedrock (Harned, 1989). Less flow probably takes place in deeper bedrock that extends beneath the Coastal Plain. In addition, flow in bedrock is localized along fractures that, in most cases, do not extend areally more than a few hundred feet or that remain open below shallow depths (Richardson, 1980). Localized conditions possibly exist in the Fall Zone where flow to and (or) from bedrock occurs within highly developed fractures that persist at depth along particular structural features, such as faults. In most parts of the Fall Zone, however, flow probably is focused along the relatively thin zone of weathered material positioned between the bedrock and overlying Coastal Plain sediments and probably does not contribute regionally significant amounts of recharge or discharge.

\section{Simulation of Ground-Water Flow}

Although ground water flows through the unconfined and confined aquifers across much of the Fall Zone, vertical flow between the aquifers also occurs where vertical gradients between the aquifers are relatively large. The volume of water flowing through and between the aquifers, however, depends also on the vertical and horizontal hydraulic conductivities of the aquifers and confining units and on their three-dimensional configurations and boundaries. Hence, estimation of volumetric flow rates requires some form of quantitative analysis.

In order to estimate volumetric rates of different components of ground-water flow in the Fall Zone under different conditions, ground-water flow was simulated by two models using MODFLOW, a modular three-dimensional finite-difference ground-water-flow model developed by the USGS (McDonald and Harbaugh, 1988). Information from the descriptions of 


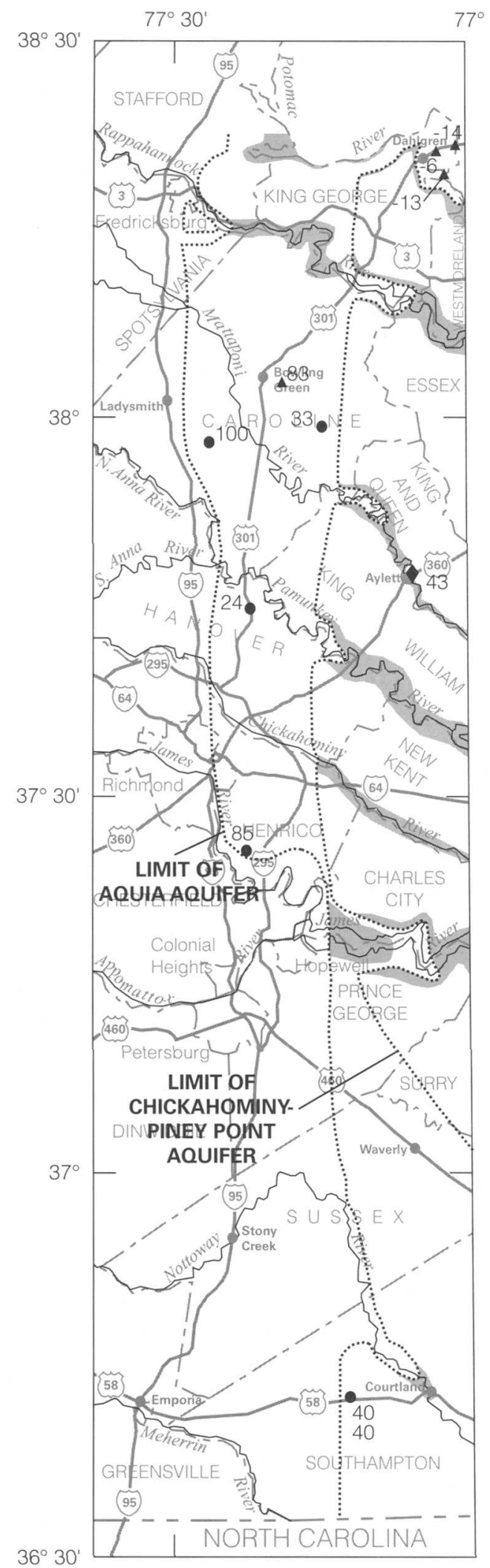

\section{EXPLANATION}

AQUIFER SUBCROP AREA

STATEWIDE NETWORK WELL IN THE AQUIA AQUIFER AND APPROXIMATE WATER-LEVEL ELEVATION, IN FEET.

Datum is sea level

33. OBSERVATION WELL IN THE AQUIA AQUIFER MAINTAINED FOR THIS STUDY AND APPROXIMATE WATER-LEVEL ELEVATION, IN FEET. Datum is sea level

OBSERVATION WELL IN THE CHICKAHOMINY-PINEY POINT AQUIFER MAINTAINED FOR THIS STUDY WELL (54L 10) AND APPROXIMATE WATER-LEVEL ELEVATION, IN FEET. Datum is sea level

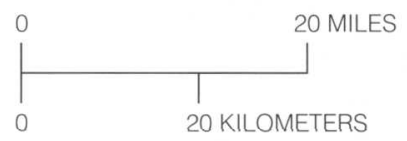

Figure 24. Water-level elevations in the Chickahominy-Piney Point aquifer and Aquia aquifer in the Fall Zone of Virginia. 

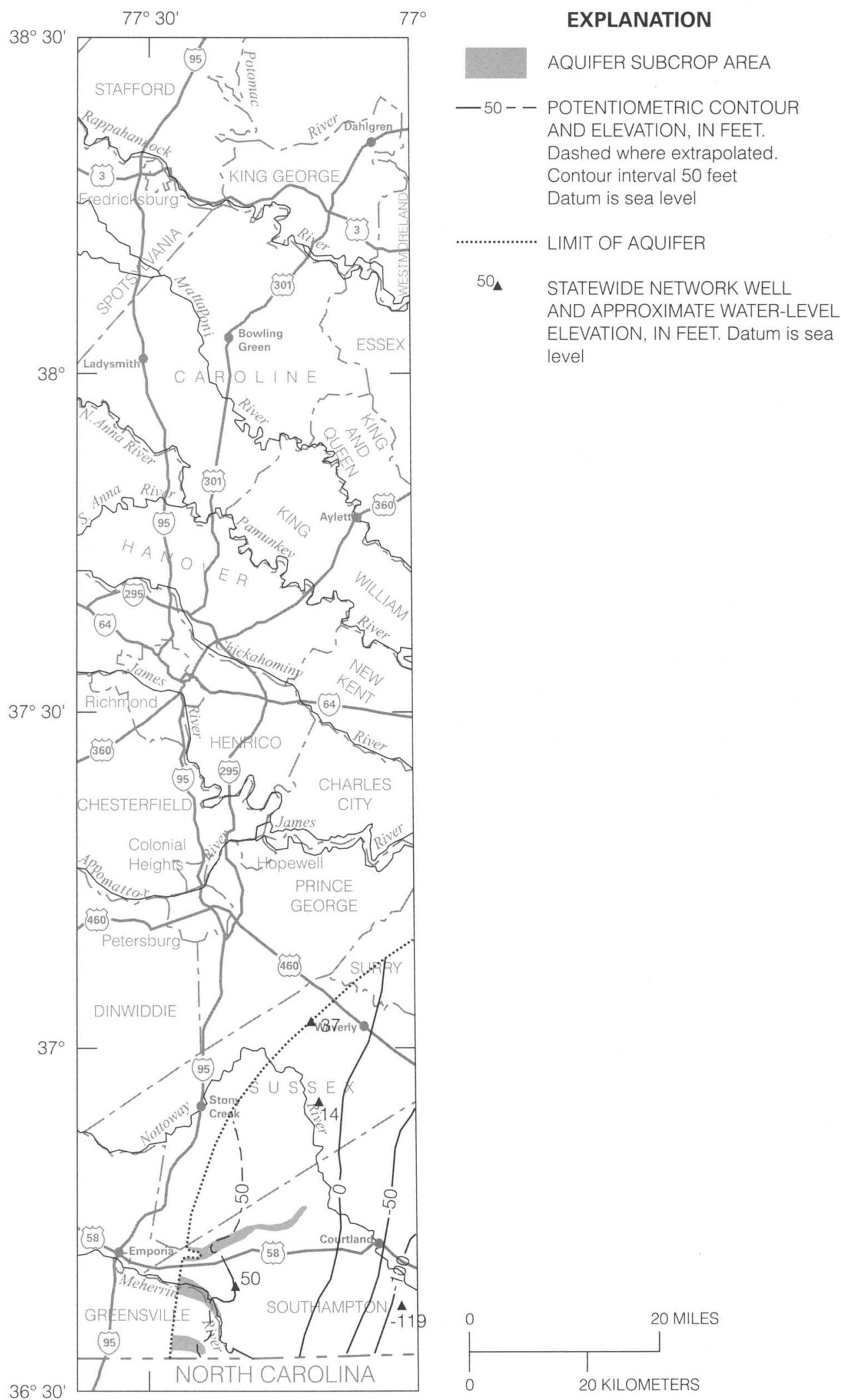

Figure 25. Water-level elevations in, and the potentiometric surface of, the upper Potomac aquifer in the Fall Zone of Virginia. 


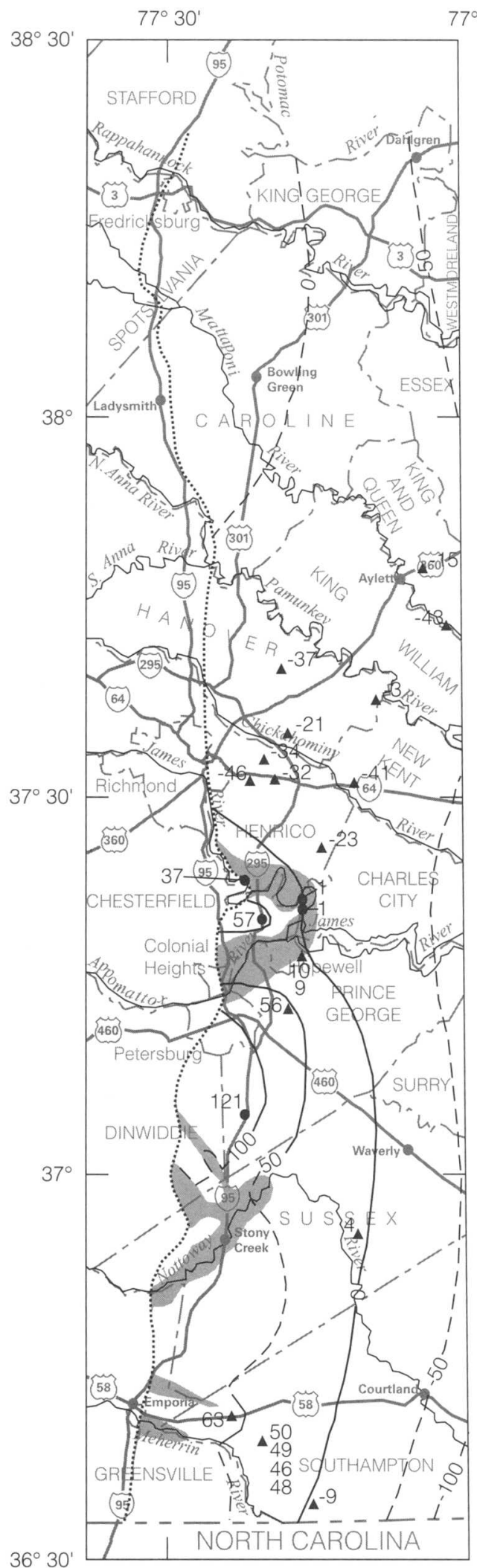

\section{EXPLANATION}

AQUIFER SUBCROP AREA

- 50- - POTENTIOMETRIC CONTOUR AND ELEVATION, IN FEET.

Dashed where extrapolated

Contour interval 50 feet.

Datum is sea leve

LIMIT OF AQUIFER

56. STATEWIDE NETWORK WELL AND APPROXIMATE WATER-LEVEL ELEVATION, IN FEET. Datum is sea level

37. OBSERVATION WELL MAINTAINED FOR THIS STUDY AND APPROXIMATE WATER-LEVEL ELEVATION, IN FEET. Datum is sea level

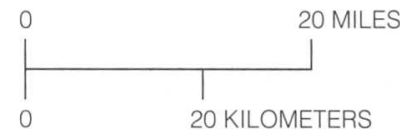

Figure 26. Water-level elevations in, and the potentiometric surface of, the middle Potomac aquifer in the Fall Zone of Virginia. 

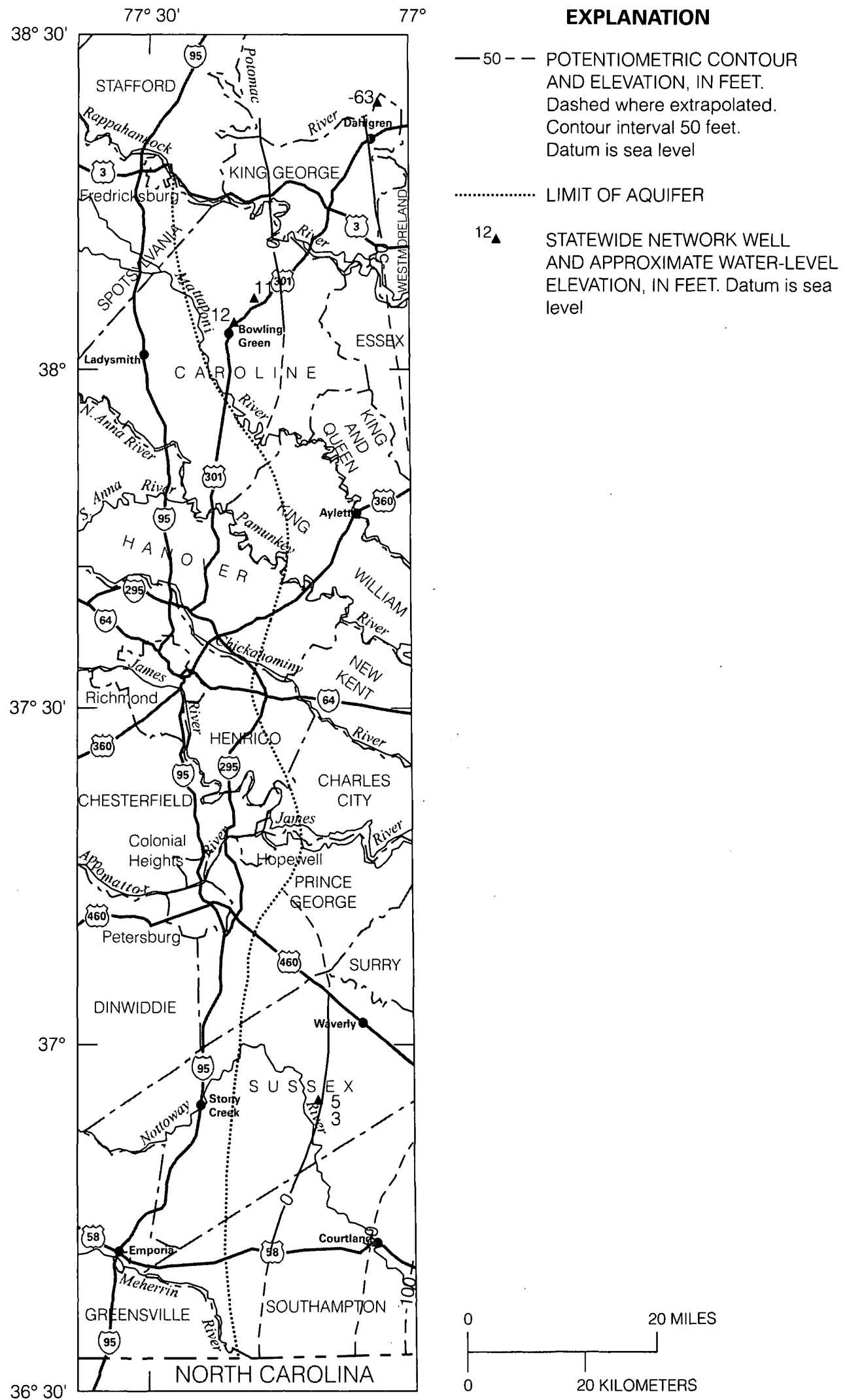

EXPLANATION

Figure 27. Water-level elevations in, and the potentiometric surface of, the lower Potomac aquifer in the Fall Zone of Virginia. 
the hydrogeologic framework and ground-water-flow system presented in this report were used to construct the models.

The design of both of the models presented in this report allowed them to be compared to a localscale model that was constructed during the initial phase of the study (McFarland, 1997). The previous model (the James model), which was configured around a segment of the James River Basin that crosses the Fall Zone (fig. 28), was used to evaluate the accuracy and consistency of descriptions of the hydrogeologic framework and ground-water-flow system. Ground-water traveltimes estimated by particle-tracking analysis using the James model were found to be consistent with independently obtained ground-water ages determined on the basis of concentrations of chlorofluorocarbons. The James model was then used to calculate volumetric rates of components of ground-water flow, including local discharge, vertical leakage, and regional recharge.

The two local-scale models constructed during the second phase of the study are similarly configured around segments of the drainage basins of other major rivers that cross the Fall Zone (fig. 28): one model encompasses the Nottoway River (the Nottoway model) and the other model encompasses the Pamunkey River (the Pamunkey model). All three models encompass drainage basin segments that include the lowlands along the rivers and the adjacent uplands along the drainage divides. The areas encompassed by the Nottoway and Pamunkey models, however, were selected to represent hydrogeologic conditions that contrast with those within the area encompassed by the James model. In both the Nottoway and the James model areas, broad floodplain and terrace deposits that compose the unconfined aquifer are incised entirely through the middle Potomac confining unit and into the confined middle Potomac aquifer, resulting in extensive aquifer subcrop areas (fig. 17). The Nottoway River is shallower and narrower than the James River, however, and its flow (mean annual rate $1352 \mathrm{ft}^{3} / \mathrm{s}$; White and others, 1997) is less than one-sixth of that in the James River (greater than $9000 \mathrm{ft}^{3} / \mathrm{s}$ as estimated from upstream gages; White and others, 1997). The Pamunkey River also is shallower and narrower than the James River, and flow (approximately $1600 \mathrm{ft}^{3} / \mathrm{s}$ as estimated from upstream gages; White and others, 1997) also is approximately one-sixth of that in the James River. Unlike either the James or Nottoway models, however, the Pamunkey model encompasses an area in which relatively narrow floodplain and terrace deposits that compose the unconfined aquifer are incised only partway into the Nanjemoy-Marlboro confining unit. As a result, subcrop areas of the underlying confined Aquia (fig. 13) and middle Potomac (fig. 17) aquifers are not present.

The local-scale James, Nottoway, and Pamunkey models were constructed instead of one or more larger regional-scale models to represent the range of hydrogeologic conditions present across most of the Fall Zone. Evaluation of the James model indicated that the hydrogeologic framework and ground-waterflow system were accurately and consistently represented (McFarland, 1997). Accordingly, similar model scales, layers, and boundaries were incorporated in the Nottoway and Pamunkey models so that simulation results would be comparable to those from the James model. In addition, the local-scale models can discretize the model areas with sufficient detail to represent the complex configurations of the aquifers and confining units without requiring unmanageably large data sets.

\section{Model Layers and Boundary Conditions}

Ground-water flow can be described mathematically by partial differential equations that cannot be solved exactly except when they describe very simple flow systems. Finite-difference models, such as those constructed for this study, consist of a series of algebraic equations that approximately describe ground-water flow between specified aquifer subsections represented by cells that make up a grid. The hydraulic characteristics of the aquifers, any sources or sinks of water other than flow from adjacent cells, and an initial approximation of hydraulic head are specified for each cell. In addition, the model areas are defined by boundaries along which conditions of flow or hydraulic head are specified. Using iterative calculations, computer programs simultaneously solve the series of equations for the hydraulic head and the rate and volume of ground-water flow in each aquifer cell.

Although the ground-water-flow systems in the Nottoway and Pamunkey model areas are complex, the characteristics of the flow system described in this report were used to define boundary conditions that allow the flow system to be translated into 
comparatively simple forms for mathematical simulation. Lateral and vertical model boundaries were defined using the conventions of Franke and others (1987).

The Nottoway model contains two layers and the Pamunkey model contains three layers (fig. 29). In both models, the upper layer represents the unconfined aquifer and the lower layer represents the confined middle Potomac aquifer. Additionally in the Pamunkey model, a middle layer represents the confined Aquia aquifer. Vertical, lateral, and internal boundaries of all layers were defined to approximate actual conditions. The elevations of the tops of the upper layers were designated by the water table, which was simulated as a fluctuating surface in the unconfined aquifer across which flow is specified as areal recharge. The lower layers are bounded at their base by a no-flow boundary, which corresponds to bedrock underlying the middle Potomac aquifer.

Grids of square cells scaled to $2,083 \mathrm{ft}$ along each side were superimposed on topographic maps of the model areas to discretize the layers making up the Nottoway (fig. 30) and Pamunkey (fig. 31) models. All sides of the upper layer in both models were specified as no-flow boundaries. The western side of the upper layer in both models was positioned toward the Fall Line only as far west as the limit of hydraulically contiguous confined aquifers (fig. 28). Surficial deposits composing the unconfined aquifer that extend farther west form caps that function hydraulically as part of the unconfined aquifer overlying bedrock in the Piedmont (see section "Hydrogeologic Framework"), where water leaks downward into fractures in the underlying bedrock. By contrast, where confined aquifers are present farther east, downward leakage from the surficial deposits is into the underlying aquifers.

The no-flow boundaries along the remaining sides of the upper layer in both the Nottoway (fig. 30) and Pamunkey (fig. 31) models were positioned to coincide with water-table divides that were inferred from topographic divides. Because the hydraulic gradient within the unconfined aquifer is represented by the slope of the water table, water-table divides represent boundaries along which no flow occurs. Although the position of the water table was not measured within either the Nottoway or Pamunkey model areas, the shape of the water table within both model areas was assumed to be subparallel to the land surface (see section "Description of the Ground-Water-
Flow System"). Most of the water-table divide boundaries coincide with the drainage basin boundaries of the Nottoway and Pamunkey Rivers. Short lengths of the water-table divide boundaries located farthest east coincide with tributary stream basin boundaries within the Nottoway and Pamunkey Basins.

Within both model areas, unconfined ground water flows primarily from near the Fall Line and water-table divides toward, and discharges to, the major rivers and their tributary streams. Accordingly, head-dependent flow cells (stream cells) were specified in the upper layers to correspond to the rivers and streams (figs. 30 and 31). The simulated rate of discharge through the stream cells can fluctuate and is a function of (1) the simulated difference between head in the aquifer and the stream stage, and (2) the specified conductance of streambed material within the cells.

The westward extents of the confined Aquia and middle Potomac aquifers lie along the Fall Line boundaries as designated for the upper model layers. Accordingly, no-flow boundaries were specified along the western sides of the lower layers of both models, and of the middle layer of the Pamunkey model, to correspond with the aquifer limits (figs. 30 and 31).

Within both model areas, regional directions of flow in the middle Potomac aquifer were inferred generally to be toward the east, although probably also directed locally toward discharge in the subcrop area along the Nottoway River (see section "Description of the Ground-Water-Flow System"). Accordingly, noflow boundaries were specified for the lower layers along the northeastern and southeastern sides of the Nottoway model (fig. 30) and along the northern and southern sides of the Pamunkey model (fig. 31), and are approximately parallel to directions of flow. Confined ground water that leaves both model areas, referred to as regional recharge, flows through the middle Potomac aquifer toward the east to areas located downgradient. Accordingly, constant-head boundaries were specified for the lower layers along the eastern sides of both models (figs. 30 and 31). Hydraulic head in the middle Potomac aquifer was not measured along the constant-head boundaries within either of the model areas. Instead, head values of $50 \mathrm{ft}$ for the Nottoway model, and ranging from -18 to $-20 \mathrm{ft}$ for the Pamunkey model, were inferred from the distribution of water-level elevations outside of the model areas (fig. 26) and assigned to cells along the constant-head boundaries. The simulated rate of 


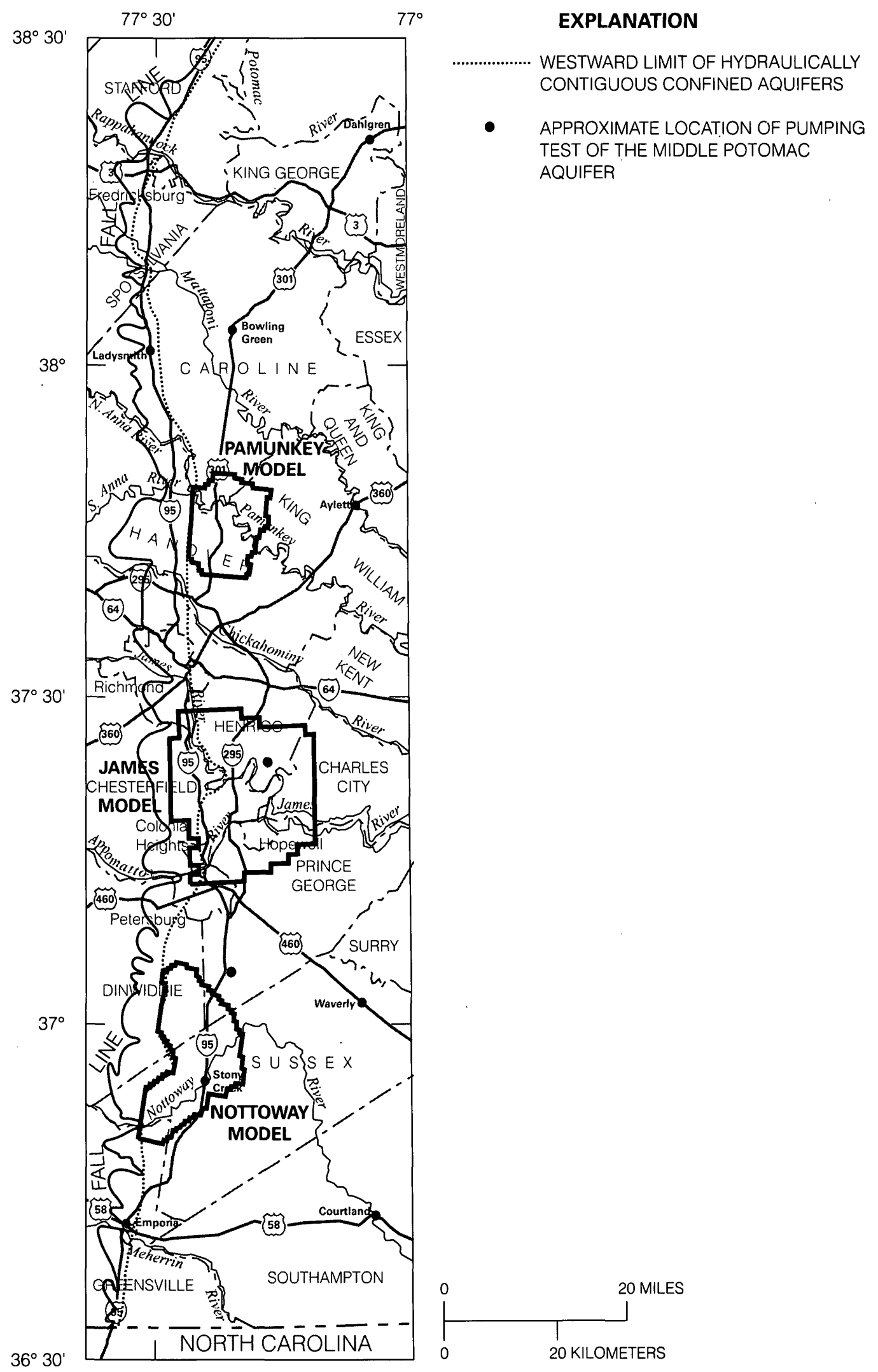

Figure 28. Locations of local-scale ground-water-flow model areas and of pumping tests of the middle Potomac aquifer in the Fall Zone of Virginia. James model from McFarland (1997). 
discharge across the constant-head boundaries can fluctuate, but head remains constant. To remain conceptually valid, the constant-head cells must only accept and not supply water during simulations.

Within the Pamunkey model area, confined ground water also flows through the Aquia aquifer, which is positioned below the unconfined aquifer and above the confined middle Potomac aquifer (fig. 29). The direction of flow through the Aquia aquifer, however, cannot be determined from available data (see section "Description of the Ground-Water-Flow System"). Although some confined ground water likely leaves the model area by flowing through the Aquia aquifer to the east, the aquifer's thickness is approximately one-tenth that of the underlying middle Potomac aquifer, and the resulting transmissivity also is probably much less (approximately one-tenth assuming equal hydraulic conductivities for both aquifers). Hence, most of the flow out of the model area is probably through the middle Potomac aquifer. In addition, flow direction through the Aquia aquifer possibly is influenced by discharge along the Pamunkey River, where the overlying NanjemoyMarlboro confining unit is thin because of incision by the river and associated floodplain and terrace deposits. Accordingly, no-flow boundaries were specified for the middle layer along the northern, southern, and eastern sides of the Pamunkey model (fig. 31). The middle layer thereby functions as a zone within which flow can be areally redistributed between vertical leakage with the overlying unconfined aquifer and the underlying confined middle Potomac aquifer.

Within both model areas, some ground water is withdrawn from water-supply wells, but withdrawals were not included in either the Nottoway or Pamunkey flow models. Both areas are largely rural, and most wells likely are widely dispersed and used for small domestic or commercial supplies, from which wastewater typically is returned through on-site septic systems. Data are generally lacking, however, for most withdrawals. A few small withdrawals were reported to DEQ during 1996 (the most recent year for which data are available). Within the Nottoway model area, two withdrawals were reported, which had an average rate of $9.7 \mathrm{gal} / \mathrm{min}$ and were equivalent to approximately $0.005 \mathrm{in} / \mathrm{yr}$. Within the Pamunkey model area, 19 withdrawals were reported, which had an average rate of $8.7 \mathrm{gal} / \mathrm{min}$ and were equivalent to approximately $0.07 \mathrm{in} / \mathrm{yr}$. Withdrawals probably were no larger prior to 1996 because development was not significantly greater in either model area. In addition, because neither area is served by extensive sewer systems, most of the ground water removed by the reported withdrawals is likely returned through septic systems. Small withdrawals and subsequent septic-system returns within the model areas could result in local redistribution of ground water, which likely is not discernible at the scale at which the models are constructed. Moreover, the withdrawals and returns probably result in very little or no removal of the total volume of water from the system.

Recharge to both model areas is simulated as areal recharge at the water table in the unconfined aquifers (fig. 29). From the water table, water flows laterally through the unconfined aquifers and leaks downward into the confined middle Potomac aquifer and, in the Pamunkey model, the confined Aquia aquifer. Water also can leak upward from the confined aquifers into the unconfined aquifers. Ground water leaves the model areas as either (1) discharge from the unconfined aquifers to the rivers and streams or (2) flow from the confined middle Potomac aquifer across the constant-head boundary.

\section{Model Data Input}

After model boundaries were defined, hydrologic data were specified for input to the model computer programs. Where possible, model input data were based on available information, but values for some inputs had to be estimated initially on the basis of the types and distributions of subsurface materials in the model areas. These values were adjusted during model calibration.

Ground-water flow in the model areas was simulated under steady-state conditions. Steady-state simulations provide static representations of the flow system that indicate a nonchanging spatial distribution of flow. Mathematical representations of steady-state ground-water flow generally consist of systems of equations that relate input values for (1) hydraulic head, (2) volumetric flow rate, and (3) hydraulic conductivity. If two of the input values are known, the equations can be solved for the third value. In this study, information was available for all three input values, but each value had different sources and degrees of error. 

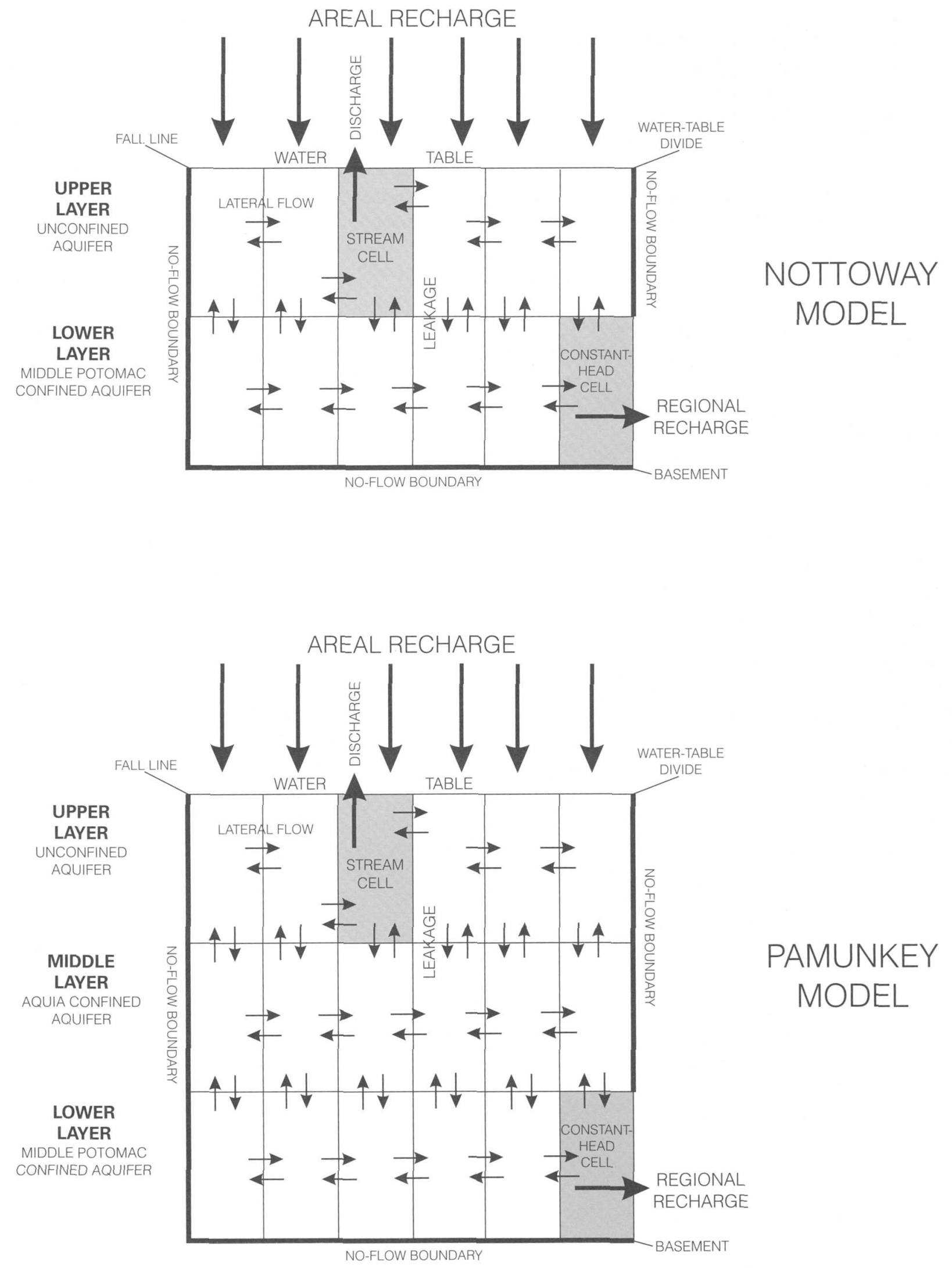

Figure 29. Conceptualized ground-water-flow systems in the Fall Zone of Virginia. 

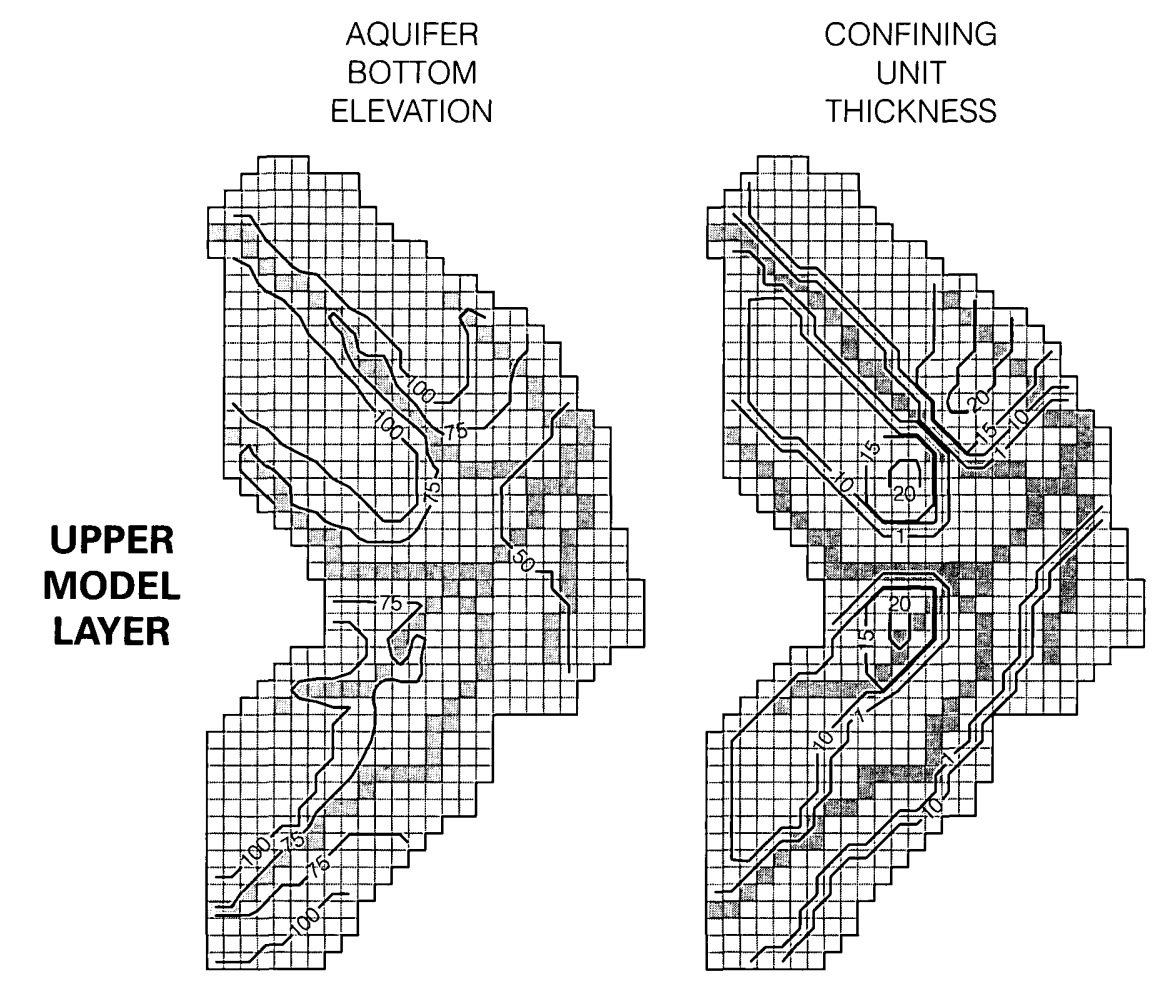

\section{EXPLANATION}

$\square$ MODEL CELL

- MODEL STREAM CELL

一 NO-FLOW BOUNDARY

.......... CONSTANT-HEAD BOUNDARY

-50- CONTOUR-Units in feet. Interval is variable
AQUIFER

THICKNESS

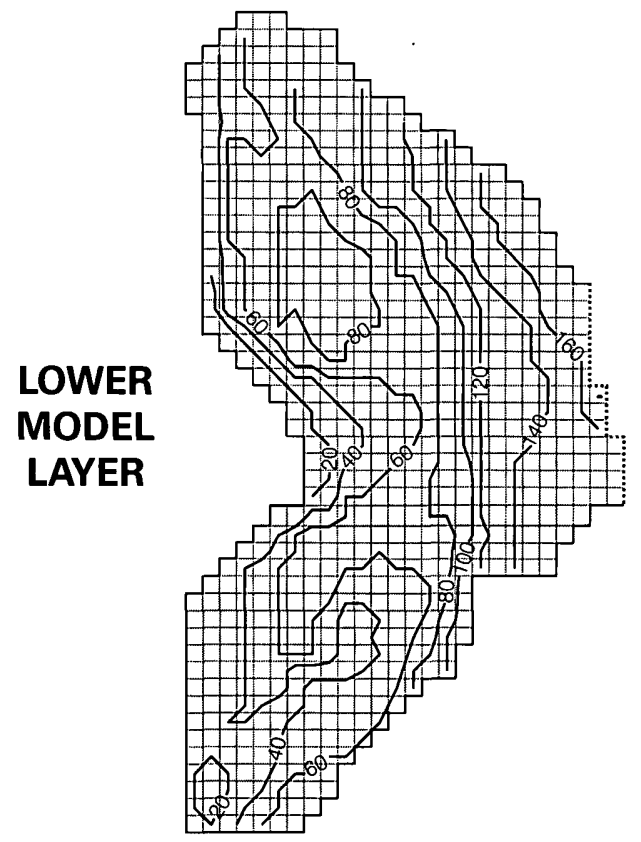

SIMULATED

WATER-TABLE

ELEVATION

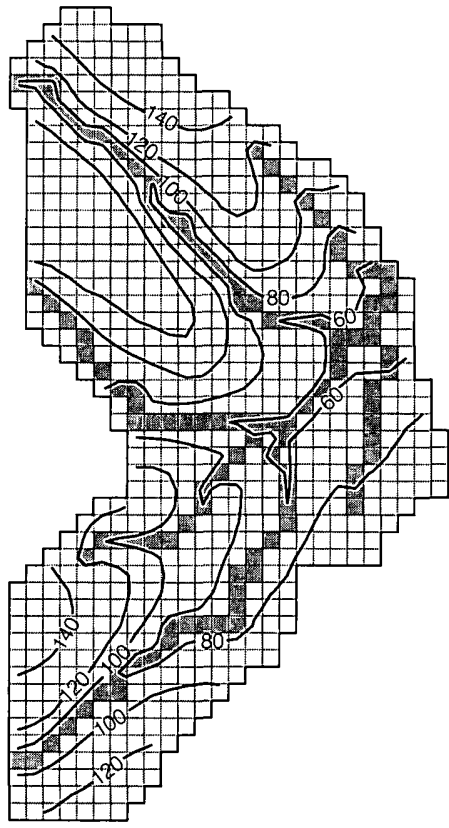

SIMULATED

HEAD

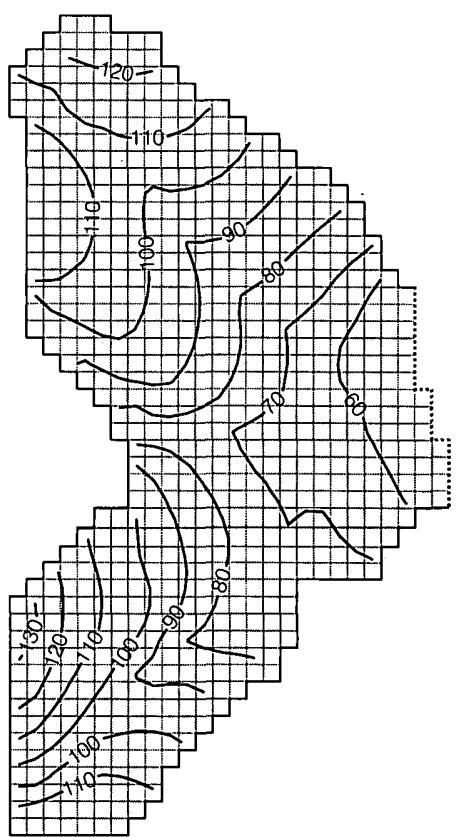

Figure 30. Aquifer and confining unit configurations and simulated water-table elevations and heads, for the calibrated Nottoway model in the Fall Zone of Virginia. 

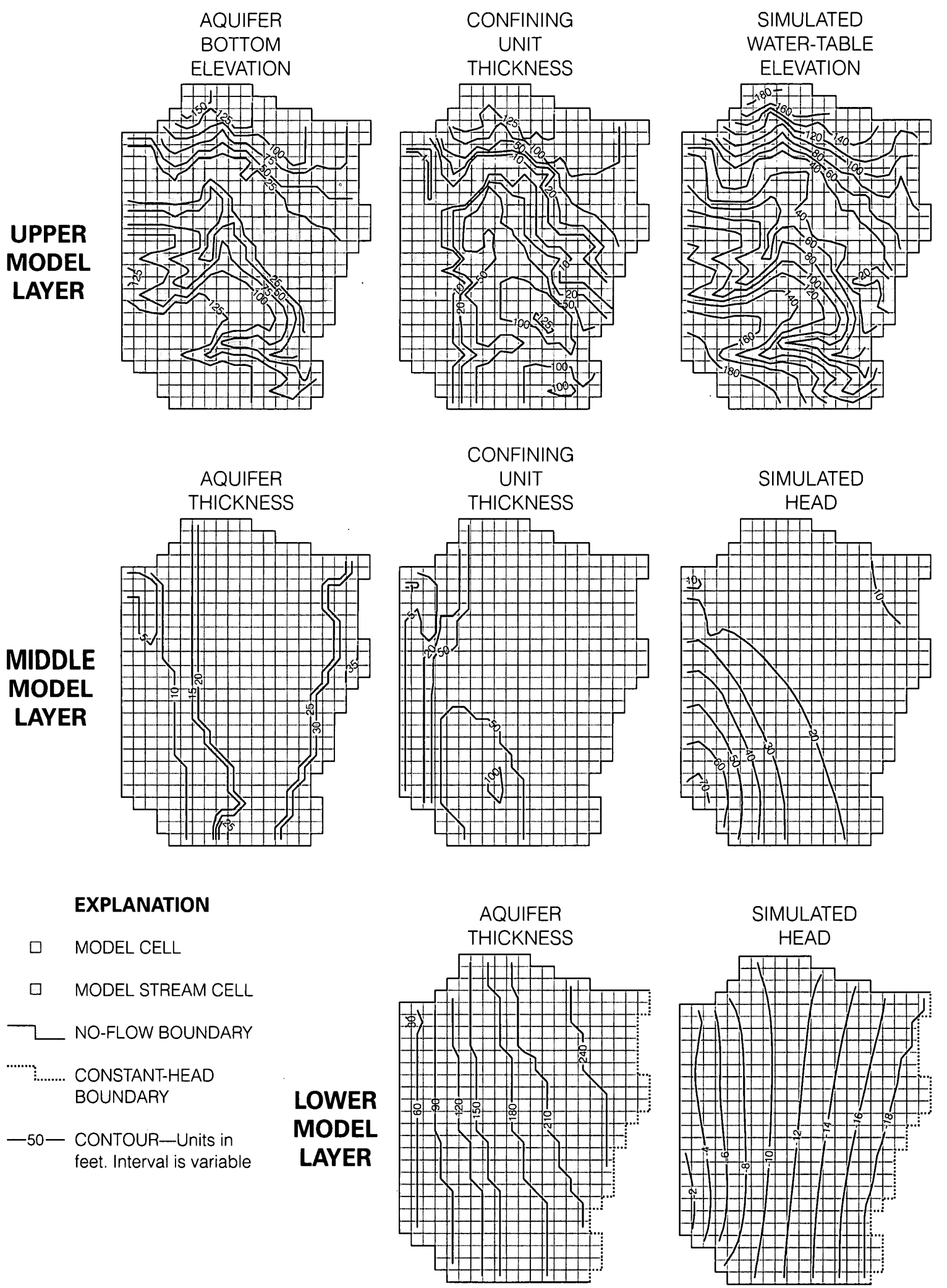

Figure 31. Aquifer and confining unit configurations, and simulated water-table elevations and heads, for the calibrated Pamunkey model in the Fall Zone of Virginia. 
Hydraulic head usually is estimated from waterlevel elevations in wells open to an aquifer. Some wells in the Fall Zone that are open at different depths at a single areal location exhibit different water levels because of vertical hydraulic gradients within or between aquifers (figs. 25-27). In contrast, modelsimulated hydraulic head for a single layer represents a vertically constant value (Cooley and Naff, 1990). For vertical gradients within a single aquifer to be simulated, the aquifer must be divided into more than one layer. Conversely, if vertical gradients between aquifers are to be simulated, individual aquifers can be simulated as single layers in which average head is estimated from measured water levels. Because vertical gradients between the unconfined and confined aquifers in the model areas are significant, separate model layers were used to represent the different aquifers. Although not measured, hydraulic head in the unconfined aquifer is equivalent to the position of the water table, which can be inferred from topography probably to within $10 \mathrm{ft}$ (see section "Description of the Ground-Water-Flow System"). For the confined aquifers, only one well (52L 9, fig. 6) from which a water-level elevation was calculated is located within either model area. The distribution of water-level elevations (calculated to within $5 \mathrm{ft}$ at well locations) in the confined aquifers throughout the Fall Zone, however, indicates their likely range of hydraulic head, assuming continuity across the model areas.

The volumetric flow rate is equivalent to recharge as the only source of water to the model areas (assuming that constant-head boundary cells only accept and do not supply water). On the basis of numerical regression techniques using streamflow data, estimates of net annual ground-water recharge of approximately $10 \mathrm{in} / \mathrm{yr}$ were obtained in the Virginia Coastal Plain (Richardson, 1994) and in the Maryland Coastal Plain (McFarland, 1995). These estimates represent net recharge that is discharged subsequently to streams, but do not include water that is removed from the aquifer by evapotranspiration. Because of local variations, the estimates could differ from recharge within the model areas by several inches per year.

The hydraulic conductivity of many subsurface materials is increasingly heterogeneous at small scales. Consequently, some estimates of hydraulic conductivity can vary by several orders of magnitude over distances as short as a few feet, and all estimates are valid only at the scale at which the estimates are made (Bradbury and Muldoon, 1990). Appropriate use of hydraulic-conductivity estimates depends on the size of the area to be analyzed and the volume of subsurface material of interest. Calibration of a ground-water-flow model requires hydraulic-conductivity values that are representative of the subsurface material at the scale at which the model is constructed.

Hydraulic conductivity is incorporated in the models in different ways to represent conditions of horizontal flow within aquifers, vertical flow between aquifers, and flow through other materials such as streambeds. On the basis of slug tests, some estimates of the horizontal hydraulic conductivity of both the unconfined aquifer and the confined middle Potomac aquifer within the Fall Zone were obtained near the James River during the initial phase of this study (McFarland, 1997), but these estimates generally represent conditions only near the tested wells. Pumping tests, which impose larger hydraulic stresses within the aquifer than slug tests, can effectively average small-scale heterogeneities in hydraulic properties and provide the basis for estimates that represent a much larger volume of the aquifer. Two estimates of horizontal hydraulic conductivity based on pumping tests were obtained for the middle Potomac aquifer (fig. 28). At one location in Henrico County (H. Wigglesworth, County of Henrico Public Utilities, written commun., 1990), aquifer test results indicated a hydraulic conductivity of approximately $20 \mathrm{ft} / \mathrm{d}$. At another location in Prince George County (T.S. Bruce, Virginia Department of Environmental Quality, written commun., 1998), a hydraulic conductivity of approximately $50 \mathrm{ft} / \mathrm{d}$ was indicated. The available aquifer-test information possibly is not representative of the entire Fall Zone, but it does indicate a probable range for the hydraulic conductivity of the middle Potomac aquifer.

Because both models simulate vertical flow between the unconfined and confined aquifers, additional model inputs are required to represent conditions of vertical flow between the aquifers. Although horizontal hydraulic conductivity is input to the model to represent flow within model layers, the vertical hydraulic conductivity of each layer is not specified. Instead, vertical leakance is specified to represent the conductance of water between $\mathrm{m}$ : $\mathrm{de}$ layers. Vertical leakance is based on a thicknes:weighted average of the vert cal hydraulic conductivities of adjacent layers. To represent confining units, vertical leakance values are assigned to 
the model aquifer layer for the confining unit underlying the aquifer. Hence, in the Nottoway model, vertical leakance values assigned to the upper layer represent the middle Potomac confining unit. In the Pamunkey model, vertical leakance values assigned to the upper layer represent the Nanjemoy-Marlboro confining unit, and those assigned to the middle layer represent the middle Potomac confining unit. No estimates of vertical hydraulic conductivity, however, were obtained within the Fall Zone.

Lastly, model inputs are required to represent conditions in which ground water is discharged from the upper model layers through head-dependent flow cells (stream cells) that correspond to the major rivers and their tributary streams (figs. 30 and 31 ). The amount of discharge is determined by the simulated difference between the head in the aquifer and the stage of the stream, and the specified conductance of streambed material. Cells representing the rivers and streams were assigned stream-stage values that correspond to the approximate elevations of the rivers and streams in each cell. The conductance of the streambed material depends on the geometric configuration of the streambed (length, width, and thickness within each model cell) and its vertical hydraulic conductivity, according to the equation

$$
C=\frac{K L W}{M}
$$

where

$\mathrm{C}$ is conductance, in square feet per day,

$\mathrm{K}$ is vertical hydraulic conductivity, in feet per day,

$\mathrm{L}$ is length, in feet,

$\mathrm{W}$ is width, in feet, and

$\mathrm{M}$ is thickness, in feet.

Streambed conditions throughout the Fall Zone are diverse. Streambed seepage rates measured along the James River during the initial phase of the study ranged over nearly two orders of magnitude (McFarland, 1997), probably because of localized variations in streambed thickness and (or) vertical hydraulic conductivity. The elevation of the water table near most major rivers and other perennial streams throughout the Fall Zone, however, generally is within a few feet or less of that of the rivers and streams. Because vertical gradients between the unconfined aquifer and rivers and streams are small, streambed materials likely have relatively high conductances that do not greatly impede discharge of ground water into the rivers and streams. For both the Nottoway and
Pamunkey models, a relatively large vertical hydraulic conductivity of $10 \mathrm{ft} / \mathrm{d}$, along with an approximate streambed thickness of $5 \mathrm{ft}$ and width of $10 \mathrm{ft}$ across the length of each stream cell $(2,083 \mathrm{ft})$, results in a streambed conductance value of $41,660 \mathrm{ft}^{2} / \mathrm{d}$ for each of the stream cells.

\section{Model Calibration and Sensitivity}

The computer programs were executed to read the input data and to write output data that represent steady-state simulations of the ground-water-flow systems in the model areas. The programs used the strongly implicit procedure (McDonald and Harbaugh, 1988) to solve the series of ground-water flow equations.

On the basis of available information, a uniform areal recharge rate of $10 \mathrm{in} / \mathrm{yr}$ was specified across both model areas, a streambed conductance of $41,660 \mathrm{ft}^{2} / \mathrm{d}$ was specified for each stream cell in the upper model layers, and a horizontal hydraulic conductivity of $50 \mathrm{ft} /$ $\mathrm{d}$ was specified for the confined aquifers in both models. Because the Aquia aquifer within the Pamunkey model area likely is composed in large part of Potomac Formation sediments (see section "Hydrogeologic Framework"), the same horizontal hydraulic conductivity value was specified for both the middle and lower Pamunkey model layers. In both models, transmissivity values for the confined aquifers were calculated during program execution by multiplying the specified horizontal hydraulic conductivity value by the thicknesses of the aquifers in each cell (also input), which range from nearly $0 \mathrm{ft}$ close to the Fall Line to as much as $240 \mathrm{ft}$ toward the eastern boundaries (figs. 30 and 31 ).

Calibration was performed by adjusting the remaining input values during repeated executions of the programs until simulated heads were within several feet or less from heads estimated at corresponding areal locations in the model areas. The shape of the water table was assumed to be subparallel to the land surface, with the water table positioned approximately 20 to $30 \mathrm{ft}$ below land surface in uplands areas along the water-table-divide boundaries and within a few feet or less of land surface in lowland areas near streams. Similarly, hydraulic head in the confined aquifers across the model areas was inferred from the distribution of water-level elevations outside of the model area. 
A stepwise procedure was followed for both models to adjust input values for horizontal hydraulic conductivities of the unconfined aquifers and vertical leakances of the confining units. Initially, values for confining unit vertical leakances were specified as zero to constrain flow to the upper layer of the models, while values for horizontal hydraulic conductivities of the unconfined aquifers were adjusted until the simulated water tables approximated their estimated elevations (figs. 30 and 31). Values for confining unit vertical leakances in both models then were adjusted. Similar to confined aquifer transmissivity values, vertical leakance values for individual cells were calculated during program execution by dividing adjusted vertical hydraulic conductivity values by the thicknesses of the confining units in each cell (also input), which range from nearly $0 \mathrm{ft}$ close to the Fall Line (as well as across the aquifer subcrop area in the Nottoway model) to as much as $125 \mathrm{ft}$ at some locations (figs. 30 and 31). Concurrently, the values for horizontal hydraulic conductivities of the unconfined aquifers were decreased slightly from their initially adjusted values to maintain the water tables at their previously adjusted elevations. Adjustment ceased when simulated heads in both the confined and unconfined aquifers approximated their estimated elevations (figs. 30 and 31). Because resulting gradients in the lower layer of both models were toward the constant-head boundary, the constant-head cells only accepted and did not supply any water and the boundary condition remained conceptually valid. The final adjusted values for horizontal hydraulic conductivities of the unconfined aquifers and vertical leakances of the confining units, along with the initially specified value for horizontal hydraulic conductivity of the confined aquifers, are referred to as the calibration input values (table 2).

Model sensitivity analyses commonly are designed to indicate the effects of input value variations on simulated heads (for example, McFarland, 1997). Differences are calculated between measured water levels and heads that are simulated using various ranges of model input values. The largest differences are produced by the most "sensitive" inputs, which thereby represent the sources of greatest uncertainty in the models. Numerical regression techniques also can be used (Cooley and Naff, 1990) to derive an "optimal" set of input values that produces the least differences between measured water levels and simulated heads.
Actual heads in both model areas presented in this report largely are only estimated (see section "Model Data-Input Requirements"). Differences between measured water levels and simulated heads can be calculated at only one location (well 52L 9 in the Aquia aquifer within the Pamunkey model area); therefore, there is no adequate basis for the sensitivity analysis described above. A sensitivity analysis was conducted, however, using the James model

(McFarland, 1997), as water-level data were relatively available in this model area. According to this analysis, recharge rate and the horizontal hydraulic conductivity of the unconfined aquifer were equally the most sensitive inputs, followed by the horizontal hydraulic conductivity of the confined aquifer and the vertical hydraulic conductivity of the confining unit, with streambed conductance the least sensitive input. In addition, virtually identical results were produced by other similarly designed local-scale models of shallow ground-water flow at locations in the Coastal Plain and in the Piedmont in Maryland (McFarland, 1995).

Because of the similar model designs, relative sensitivities among inputs to the Nottoway and Pamunkey models probably are the same as in the James model.

Because actual hydraulic conductivities of subsurface materials can vary by several orders of magnitude (see section "Model Data-Input Requirements"), hydraulic conductivity values input to the Nottoway and Pamunkey models potentially can differ more from actual conditions in the model areas than the other model inputs. Hence, volumetric rates of different components of flow calculated by the model (see section "Rates of Ground-Water Flow") are equally uncertain. In order to indicate the effects of hydraulic conductivity value variations on calculated rates of different components of flow, a sensitivity analysis was designed for both models based on alternate sets of hydraulic conductivity values. The calibration procedure was repeated four times (table 2), twice by specifying smaller values for the horizontal hydraulic conductivity of confined aquifers, and twice more by specifying larger values. In order to keep the total volumetric flow rate constant, recharge was kept at the initially specified rate. Streambed conductance 1 also was not varied because, based on the James model sensitivity analysis, it probably is a relatively insensitive input. For each repetition, the other horizontal and vertical hydraulic conductivity values were adjusted as during the initial calibration until 
Table 2. Input values and calculated rates of components of flow from local-scale ground-water-flow models constructed for the Fall Zone of Virginia

Bold figures indicate calibration input values and corresponding flow rates.Other figures indicate sensitivity analysis values and corresponding flow rates. $[<$, less than]

\section{Nottoway model}

\begin{tabular}{|c|c|c|c|c|c|}
\hline Model inputs (feet per day) & & & & & \\
\hline $\begin{array}{l}\text { Unconfined aquifer horizontal hydraulic } \\
\text { conductivity }\end{array}$ & 150 & 130 & 100 & 50 & 25 \\
\hline $\begin{array}{l}\text { Middle Potomac confining unit vertical } \\
\text { hydraulic conductivity }\end{array}$ & $5 \times 10^{-5}$ & $10^{-4}$ & $3 \times 10^{-4}$ & $4 \times 10^{-4}$ & $5 \times 10^{-4}$ \\
\hline $\begin{array}{l}\text { Middle Potomac aquifer horizontal } \\
\text { hydraulic conductivity }\end{array}$ & 10 & 20 & 50 & 100 & 150 \\
\hline \multicolumn{6}{|l|}{ Flow Rates (inches per year) } \\
\hline Direct discharge & 9.6 & 9.1 & 7.6 & 6.0 & 4.4 \\
\hline Exchange & $\underline{0.3}$ & $\underline{0.7}$ & $\underline{1.8}$ & $\underline{2.9}$ & $\underline{3.8}$ \\
\hline Total discharge & 9.9 & 9.8 & 9.4 & 8.9 & 8.2 \\
\hline Regional recharge & $\stackrel{1}{=}$ & $\stackrel{2}{=}$ & $\underline{0.6}$ & $\underline{\underline{1.1}}$ & $\underline{1.8}$ \\
\hline Total flow & 10.0 & 10.0 & 10.0 & 10.0 & 10.0 \\
\hline \multicolumn{6}{|c|}{ Pamunkey model } \\
\hline \multicolumn{6}{|l|}{ Model inputs (feet per day) } \\
\hline $\begin{array}{l}\text { Unconfined aquifer horizontal hydraulic } \\
\text { conductivity }\end{array}$ & 50 & 50 & 50 & 35 & 30 \\
\hline $\begin{array}{l}\text { Nanjemoy-Marlboro confining unit } \\
\text { vertical hydraulic conductivity }\end{array}$ & $8 \times 10^{-6}$ & $1.5 \times 10^{-5}$ & $3.5 \times 10^{-5}$ & $7 \times 10^{-5}$ & $10^{-4}$ \\
\hline $\begin{array}{l}\text { Aquia aquifer horizontal hydraulic } \\
\text { conductivity }\end{array}$ & 10 & 20 & 50 & 100 & 150 \\
\hline $\begin{array}{l}\text { Middle Potomac confining unit vertical } \\
\text { hydraulic conductivity }\end{array}$ & $3 \times 10^{-5}$ & $5 \times 10^{-5}$ & $10^{-4}$ & $2 \times 10^{-4}$ & $3 \times 10^{-4}$ \\
\hline $\begin{array}{l}\text { Middle Potomac aquifer horizontal } \\
\text { hydraulic conductivity }\end{array}$ & 10 & 20 & 50 & 100 & 150 \\
\hline \multicolumn{6}{|l|}{ Flow Rates (inches per year) } \\
\hline Direct discharge & 9.9 & 9.8 & 9.5 & 9.0 & 8.6 \\
\hline Exchange & $\leq 0.1$ & $\leq 0.1$ & $\leq 0.1$ & $\leq 0.1$ & $\leq 0,1$. \\
\hline Total discharge & 9.9 & 9.8 & 9.5 & 9.0 & 8.6 \\
\hline Regional recharge & $\underline{\underline{0.1}}$ & $\underline{\underline{0.2}}$ & $\underline{0.5}$ & $\underline{1.0}$ & $\underline{\underline{1.4}}$ \\
\hline Total flow & 10.0 & 10.0 & 10.0 & 10.0 & 10.0 \\
\hline
\end{tabular}


virtually the same simulated water-table elevations and confined aquifer heads were produced as by the calibration input values.

In addition to the effects on calculated flow rates (see section "Rates of Ground-Water Flow"), results from the above analysis indicate possible ranges of the various hydraulic conductivity values (table 2 ). Most of the adjusted values range over about an order of magnitude, with the exception of the horizontal hydraulic conductivity values for the unconfined aquifer in the Pamunkey model, which vary by a factor of less than 2. In both models, ranges are similar for horizontal hydraulic conductivity values in both the unconfined and confined aquifers and for vertical hydraulic conductivity values for the middle Potomac confining unit. Vertical hydraulic conductivity values for the Nanjemoy-Marlboro confining unit are consistently smaller than those for the middle Potomac confining unit.

The model input values were compared to published estimates of aquifer and confining unit hydraulic properties (Harsh and Laczniak, 1990; Hamilton and Larson, 1988; Laczniak and Meng, 1988). Based on tabulated data along with contour maps of the entire Virginia Coastal Plain or large parts of it, published estimates of the horizontal hydraulic conductivities of the unconfined Columbia and Yorktown-Eastover aquifers generally are between 15 to $20 \mathrm{ft} / \mathrm{d}$, and of the confined middle Potomac aquifer are approximately $50 \mathrm{ft} / \mathrm{d}$ (which equals that used among the calibration input values for both the Nottoway and Pamunkey models). Although some differences exist from the model input values, notably the unconfined aquifer horizontal hydraulic conductivity values (table 2), the published horizontal hydraulic conductivity estimates were interpolated across much larger areas than those encompassed by the Nottoway and Pamunkey models. The unconfined aquifer horizontal hydraulic conductivity values are generally consistent, however, with those obtained during calibration of the James model (McFarland, 1997). Confining unit vertical hydraulic conductivity values are consistent with published values. Vertical leakance, however, possibly is greater in the Fall Zone than elsewhere in the Coastal Plain because confining units generally are thinner than in some areas farther east.

\section{Rates of Ground-Water Flow}

In order to infer relations between the local-scale flow systems within the model areas and the regionalscale flow system, rates of ground-water flow into, through, and out of the aquifers were calculated by both models (table 2 ). In order to be directly comparable, all flow rates were normalized for the model areas in units of in/yr. Comparisons were made among flow rates of water that leaves the model areas by (1) discharging directly from the upper unconfined aquifer layers through head-dependent cells (stream cells) representing major rivers and their tributary streams (direct discharge); (2) leaking initially downward from the upper unconfined aquifer layers and into confined aquifer layers, and subsequently leaking upward back into the unconfined aquifer layers and discharging through stream cell (exchange); and (3) leaking downward from the upper unconfined aquifer layers and into confined aquifer layers, and subsequently flowing through the constant-head boundaries along the eastern sides of the lower confined middle Potomac aquifer layers (regional recharge).

Direct discharge and exchange together represent the total ground-water discharge to the rivers and streams (table 2), which together with regional recharge, represents the total flow. Because both models performed steady-state simulations, there is no net change in the amount of water stored in the aquifers, and the rate at which water was specified to enter the flow systems as recharge represents the total simulated flow rate.

In both models, the total simulated flow rate of water entering the model areas was specified as $10 \mathrm{in} / \mathrm{yr}$ of recharge at the water tables in the upper unconfined aquifer layers. From the water tables, most of the ground water flows laterally through the unconfined aquifer layers of both models and discharges directly to rivers and streams, but some leaks downward into confined aquifer layers (table 2). On the basis of the calibration input values, the Nottoway model indicates that more than half of the water that leaks downward into the confined aquifer layer subsequently leaks upward back into the unconfined aquifer layer, being exchanged between the layers, before it is added to the total discharge to the rivers and streams. The Nottoway model encompasses an area in which broad floodplain and terrace deposits that compose the unconfined aquifer are incised 
entirely through the middle Potomac confining unit and into the confined middle Potomac aquifer, resulting in an aquifer subcrop area that promotes exchange.

The James model (McFarland, 1997) encompasses an area similar to the Nottoway model area. Of the total recharge of $10 \mathrm{in} / \mathrm{yr}$, flow rates calculated by the James model include direct discharge of $8.9 \mathrm{in} / \mathrm{yr}$, exchange of $0.5 \mathrm{in} / \mathrm{yr}$, and regional recharge of $0.5 \mathrm{in} / \mathrm{yr}$ (as well as the remaining $0.1 \mathrm{in} / \mathrm{yr}$ as well withdrawal). Rates of exchange and regional recharge calculated by the James model could be biased low, however, because a relatively small hydraulic conductivity for the middle Potomac aquifer of $10 \mathrm{ft} / \mathrm{d}$ was used. Other parts of the Fall Zone containing extensive aquifer subcrop areas possibly have large rates of exchange.

By contrast to both the Nottoway model and the James model, the Pamunkey model indicates that less water leaks downward into the confined aquifer layers, and virtually no water leaks upward back into the unconfined aquifer layer (table 2). The Pamunkey model encompasses an area in which relatively narrow floodplain and terrace deposits that compose the unconfined aquifer are incised only partway into the Nanjemoy-Marlboro confining unit. As a result, subcrop areas of the underlying confined Aquia and middle Potomac aquifers are not present, and exchange is impeded. Because virtually no exchange takes place, resulting rates of discharge and regional recharge are similar to the Nottoway and James models. Other parts of the Fall Zone lacking extensive aquifer subcrop areas possibly have relatively small rates of exchange, although rates of regional recharge could still be similar to areas containing subcrops.

Sensitivity analyses using both models indicate that large confined aquifer horizontal hydraulic conductivity values correspond with large rates of regional recharge, as well as large rates of exchange for the Nottoway model, but with small rates of direct discharge (table 2). As the confined aquifers were represented to be increasingly transmissive, and the confining units more leaky, flow into and through the confined aquifers increased and flow through the unconfined aquifers decreased.

Stream baseflow was not measured within either model area to allow comparison to simulated rates of ground-water discharge (total discharge). Because the model areas span segments of the Nottoway and Pamunkey Rivers, calculation of ground-water discharge from within the model areas would require measuring baseflow at a downstream location along the river flowing out of each model area and subtracting the baseflow measured at an upstream location flowing into the model area. By contrast, available streamflow data for the Nottoway and Pamunkey Rivers (White and others, 1997) are from locations that represent drainage from areas upstream and outside of the model areas, parts of which include areas in the Piedmont to the west where drainage characteristics could differ from those within the Coastal Plain.

Richardson (1994) studied ground-water discharge within the Virginia Coastal Plain. Using hydrograph separation methods, rates of ground-water discharge at individual stream-gaging stations were estimated to range from 7.51 to $12.51 \mathrm{in} / \mathrm{yr}$. An alternative method, based on classifying different parts of the Virginia Coastal Plain into "hydrogeologic areas," estimated a narrower range from 7.9 to $11.1 \mathrm{in} / \mathrm{yr}$ for drainage basins spanning most of the Virginia Coastal Plain. Rates of ground-water discharge (total discharge) simulated by the Nottoway and Pamunkey models (table 2) are generally near the middle of the ranges estimated by Richardson (1994).

Despite diverse hydrogeologic conditions among different parts of the Fall Zone, rates of total discharge and regional recharge appear to be relatively uniform across the Fall Zone, as indicated by the Nottoway, Pamunkey, and James models. The presence or absence of aquifer subcrop areas appears primarily to either promote or impede, respectively, flow that is locally exchanged between the unconfined and confined parts of the flow system prior to discharging locally.

\section{Model Limitations}

Ground-water-flow models provide only approximate representations of the flow systems. A single unique mathematical solution cannot be found to the system of equations that represent ground-water flow. Model input values represent only one possible input-value set, and model results are dependent on the assumption that the values input to the models represent the ground-water-flow systems in the model areas. In addition, steady-state simulations do not represent changes in flow over time. Rates of various components of flow are likely to vary daily, seasonally, and yearly in response to fluctuations in streamflow and evapotranspiration rate related to changing climatic conditions. 
Representations of the ground-water-flow systems by the Nottoway and Pamunkey models are inexact, primarily because of the lack of data measured within the model areas that could be used to aid model construction. Construction of the James model during the initial study phase relied on detailed field investigations, which provided local-scale observational control for model layer and boundary design, calibration, and sensitivity analysis. The same level of local-scale investigation was not possible during the second phase of the study, which incorporated most of the entire Fall Zone in Virginia. A need was recognized, however, to compare the results of the James model to other parts of the Fall Zone. Construction of a single regional-scale model spanning most or all of the Fall Zone was considered, but to provide sufficient detail to represent the complex configurations of the aquifers and confining units would require large data sets that would be difficult and time-consuming to construct. Instead, the local-scale Nottoway and Pamunkey models were constructed on the basis of the assumption that the layer and boundary design approach used for the James model could be applied to other settings within the Fall Zone. Further, it was assumed that additional information needed for model construction could be extrapolated from locations outside of the model areas.

Although a small number of the wells used to delineate the hydrogeologic framework of the Fall Zone are located within the Nottoway and Pamunkey model areas, the model layers were specified largely on the basis of the lateral extents, vertical positions, and thicknesses of aquifers and confining units delineated across the entire Fall Zone, and not solely using data from within the model areas. Some model boundaries were similarly specified, including the lateral no-flow Fall Line boundaries along the western sides of the model areas and the vertical no-flow basement boundaries at the bases of the lower model layers (fig. 29).

Other boundaries of the Nottoway and Pamunkey models were specified on the basis of information largely from outside of the model areas. The probably complex configurations of the water table within the model areas were not measured but were inferred from topography, and were used to locate no-flow boundaries on the upper model layers along water-table divides. Water levels measured mostly outside of the model areas indicated distributions of hydraulic head in the confined aquifers. Inferred regional hydraulic gradients and corresponding directions of flow through the confined aquifers were used to locate no-flow and constant-head boundaries on the lower layers in both models. In the Pamunkey model, the middle layer was constrained by no-flow boundaries to allow only horizontal redistribution of flow between vertical leakage through the adjacent confining units.

Data required to perform simulations, calibrate the models, and analyze sensitivity include hydraulic head, recharge rate, and hydraulic conductivity, and were based on diverse sources. For comparison to simulated heads, actual hydraulic heads in the aquifers within the Nottoway and Pamunkey model areas could only be estimated as described above for the boundary conditions. Hence, water-level based sensitivity analyses of the models could not be performed. Actual recharge rates within the model areas probably vary over time. On the basis of published information from other studies, long-term rates for the region are approximately $10 \mathrm{in} / \mathrm{yr}$, but likely vary locally by several inches per year. Similarly, actual hydraulic conductivities of subsurface materials within the model areas vary locally, potentially by several orders of magnitude over short distances, and likely represent the source of greatest uncertainty in the models. Accordingly, sensitivity analyses were performed to indicate the effects of hydraulic conductivity value variations on calculated rates of different components of ground-water flow.

Although the Nottoway and Pamunkey models were not constructed with the same level of observational control as the James model, the generally similar results of all three models support the conceptual validity of the model designs. In addition, differences among results of the models provide insight into how localized conditions can affect ground-water flow. The models were constructed to address the objectives for this particular study and, at best, are representative of the model areas only under the conditions existing during the study period. Other applications of the models probably would have limited validity and could produce erroneous results. Any interpretations based on the results of the models are directly dependent on the assumptions and limitations described above. 


\section{Relations Between Local and Regional Flow Systems}

Although hydrogeologic conditions within the Fall Zone are distinct, near-surface relations between the unconfined and confined flow systems in the Fall Zone share some characteristics with other parts of the Virginia Coastal Plain farther east: (1) most ground water flows entirely through the unconfined aquifer, and across relatively short distances within surfacewater drainage basins, before discharging directly to rivers and streams, (2) less ground water leaks downward to recharge confined aquifers, and (3) ground water discharges from confined aquifers along major rivers.

In a condition possibly unique to the Fall Zone, confined aquifer subcrop areas along major rivers promote the exchange of water between the unconfined and confined parts of the flow system (see section "Rates of Ground-Water Flow"). Rates of regional recharge, however, appear to be similar between parts of the Fall Zone that contain subcrop areas and those that do not. Although confined aquifer subcrop areas could be present in other parts of the Virginia Coastal Plain farther east, they have not been similarly investigated and their relations to subcrop areas in the Fall Zone cannot be evaluated.

Digital model analysis of the entire Coastal Plain aquifer system in Virginia by Harsh and Laczniak (1990) provides a basis to further relate the hydrogeologic conditions in the Fall Zone determined by this study to those throughout the Virginia Coastal Plain. Harsh and Laczniak (1990) delineated areas to distinguish between downward leakage into the confined part of the aquifer system (equivalent in this report to "regional recharge") and upward leakage from the confined aquifers into the unconfined aquifers and discharge at the land surface, both prior to and during periods when large amounts of ground water were being withdrawn. Although some areas of downward leakage in 1890 (prior to large withdrawals) were positioned along the Fall Zone, additional areas branched eastward from the Fall Zone along major surface-drainage divides to cross most of the rest of the Virginia Coastal Plain. Areas of upward leakage were positioned along major rivers across most of the Virginia Coastal Plain, including parts of the Fall Zone, as well as beneath Chesapeake Bay. By 1980, withdrawal within the Virginia Coastal Plain had increased to greater than 100 million gal/d. Areas of downward leakage had expanded to include most of the Virginia Coastal Plain, including parts of some rivers and Chesapeake Bay, and areas of upward leakage had shrunk to become narrow and fragmented.

Volumetric budgets for the entire Virginia Coastal Plain also were calculated by Harsh and Laczniak (1990) to assess to what degree the withdrawals had induced an increase in the rate of downward leakage and had intercepted some of the ground water that would otherwise discharge at the land surface. From 1890 to 1980 , the rate of downward leakage and confined aquifer recharge was estimated to have increased from 3.2 to $3.8 \mathrm{in} / \mathrm{yr}$, while discharge at the land surface decreased from 2.8 to $2.2 \mathrm{in} / \mathrm{yr}$, resulting in a withdrawal-induced net increase in regional recharge to the entire confined aquifer system from 0.4 to $1.6 \mathrm{in} / \mathrm{yr}$. Although areas of downward and upward leakage were delineated for both 1890 and 1980 , areal variations in leakage rates were not presented (such as by contouring or other means) but likely differ significantly among some areas in response to differing vertical gradients, and also could differ from the volumetric budget rates calculated for the entire Virginia Coastal Plain. Particularly near major pumping centers by 1980 , downward leakage rates resulting from large drawdowns potentially could be greater than at other locations.

Because large withdrawals within the Virginia Coastal Plain are continuing (McFarland and Focazio, 1993), the current (1999) rate of regional recharge is probably as great as that during 1980 . The 1980 rate of 1.6 in/yr estimated for the entire Virginia Coastal Plain (Harsh and Laczniak, 1990), however, is somewhat greater than regional recharge rates calculated by the local-scale models constructed for the Fall Zone (see section "Rates of Ground-Water Flow"). The 1980 rate is based on a total flow rate as areal recharge of $15 \mathrm{in} / \mathrm{yr}$, whereas the local-scale models for the Fall Zone assume $10 \mathrm{in} / \mathrm{yr}$ of recharge based on more recent regional estimates. Assuming that relative differences among the various components of ground-water flow are constant, adjusting for the lower recharge rate results in a regional recharge rate for the entire Virginia Coastal Plain of $1.1 \mathrm{in} / \mathrm{yr}$; this value is 0.5 to $0.6 \mathrm{in} / \mathrm{yr}$ greater than that obtained in the Fall Zone by the James model (McFarland, 1997) and by the Nottoway and Pamunkey models using the calibration input values (table 2), but is within the ranges produced by the sensitivity analyses of the Nottoway and Pamunkey models. 
Within the range of uncertainty of the local-scale models, estimated rates of regional recharge within the Fall Zone probably are not greater, and possibly are less, than that currently (1999) within the Virginia Coastal Plain as a whole. Prior to the onset of large withdrawals, the Fall Zone possibly represented a regionally significant source of recharge, although discharge still appears to have dominated in at least some parts of the Fall Zone near major rivers (Harsh and Laczniak, 1990). As a result of the large withdrawals, however, areas of downward leakage and regional recharge are now areally extensive throughout the Virginia Coastal Plain and not restricted to the Fall Zone. Although not demonstrated, the areas of greatest downward leakage rates would be expected near major pumping centers located farther east away from the Fall Zone, and regional recharge within the Fall Zone could be small by comparison.

Further comparison of ground-water flow in the Fall Zone with that in the rest of the Virginia Coastal Plain has been limited. Digital model analysis of the entire Coastal Plain aquifer system in Virginia (Harsh and Laczniak, 1990) represented the hydrogeologic framework within the Fall Zone differently than has been done in this study. In addition, other changes needed to the Virginia Coastal Plain model have been cited (McFarland, 1998), including more complete and (or) up-to-date information on

1. the amounts, distributions, and effects of changing withdrawals, including those located near and beyond model boundaries such as the Potomac River and the saltwater interface; and

2. the hydrogeologic framework within poorly characterized northern and central parts of the Coastal Plain in Virginia, and associated with a recently discovered meteorite or comet impact structure near the mouth of Chesapeake Bay (Powars and Bruce, 1999).

Despite the now recognized shortcomings of the original Virginia Coastal Plain model (McFarland, 1998), the correspondence between it and results obtained independently using a different study approach within the Fall Zone largely corroborate the fundamental validity of the model. Optimally, revision of the Virginia Coastal Plain model could incorporate the hydrogeologic framework of the Fall Zone as indicated in this study, along with the other cited needs. The model then could be used to provide more up-todate, as well as more quantitative, comparisons of ground-water flow in the Fall Zone to that within the rest of the Virginia Coastal Plain. Specifically, areal variations in the rates of the various components of ground-water flow could be delineated (such as by contouring or other means) within the Fall Zone and elsewhere in the Virginia Coastal Plain, to estimate the relative contributions to regional recharge by different areas. Particle-tracking techniques (Pollock, 1989) could then be applied to delineate contributing areas within the Fall Zone and elsewhere in the Virginia Coastal Plain for specific aquifer areas of interest.

\section{SUMMARY AND CONCLUSIONS}

A study was conducted during 1995-98 to improve the description of regional aquifers and confining units within the Fall Zone of Virginia, and to describe ground-water flow in the Fall Zone and its relation to regional flow in the Coastal Plain aquifer system of Virginia. The Fall Zone encompasses the western margin of the Coastal Plain, which consists of a thick sequence of stratified sediments that is underlain by a basement of largely crystalline bedrock.

A hydrogeologic framework of aquifers and confining units was delineated from the Fall Line eastward as far as 77 degrees longitude, and from Fredericksburg, Va., southward to the State line, to incorporate all of the Fall Zone that is in direct hydraulic connection with ground-water flow in the Coastal Plain aquifer system in Virginia. The unconfined aquifer within the Fall Zone is composed of Tertiary- to Quaternary-age surficial deposits of generally coarse-grained sediments that are incised to depths as great as $50 \mathrm{ft}$ into underlying confined aquifers and intervening confining units. Subcrop areas of some confined aquifers are present along parts of major rivers.

Confined aquifers and confining units were named to correspond to their principal geologic formations to facilitate comparisons to previous studies, but at some locations the aquifers and confining units are composed wholly or in part of sediments belonging to different geologic formations. The Yorktown-Eastover, Chickahominy-Piney Point, and Aquia confined aquifers, and the Yorktown, Calvert, and Nanjemoy-Marlboro confining units, generally consist of Tertiary-age marine deposits of poorly sorted, glauconitic sand with varying amounts of shell, silt, and clay that are present to elevations as 
low as $-300 \mathrm{ft}$. The aquifers are distinguished from the confining units primarily in being coarser grained and having a greater shell content.

The upper Potomac, middle Potomac, and lower Potomac confined aquifers, and the upper Potomac, middle Potomac, and lower Potomac confining units, generally consist of Cretaceous-age fluvial and deltaic deposits of medium-to-coarse-grained quartz sand with varying amounts of gravel, silt, and clay that are present to elevations as low as $-1,500 \mathrm{ft}$, and that belong mostly to the Potomac Formation. The aquifers include zones of relatively concentrated but discontinuous sand-rich beds, and the confining units include zones of relatively concentrated but discontinuous clay-rich beds.

Ground water in the Fall Zone is recharged by infiltration of precipitation and percolation to the water table. Unconfined ground water flows horizontally to discharge to nearby streams and also leaks downward to recharge confined aquifers. Recharge rates, and resulting water levels and rates of horizontal flow and downward leakage, vary seasonally and annually in response to climatic changes. Flow in confined aquifers generally is horizontal in the regionally downgradient direction toward the east. Where confined aquifers are incised by major rivers and associated floodplain and terrace deposits, however, flow is directed locally toward discharge along the rivers.

Local-scale ground-water-flow models were constructed for the Fall Zone to estimate volumetric rates of different components of ground-water flow. Of an estimated $10 \mathrm{in} / \mathrm{yr}$ of recharge at the water table, greater than $9 \mathrm{in} / \mathrm{yr}$ discharges locally to rivers and streams, and less than $1 \mathrm{in} / \mathrm{yr}$ provides recharge to the regional flow system. Where confined aquifer subcrop areas are present along major rivers, approximately $2 \mathrm{in} / \mathrm{yr}$ is exchanged locally between the unconfined and confined parts of the flow system.

Near-surface relations between the unconfined and confined flow systems within the Fall Zone are similar to those in other parts of the Virginia Coastal Plain. Previous ground-water-flow modeling of the entire Virginia Coastal Plain indicated that, as a result of large withdrawals at locations east of the Fall Zone, areas and rates of downward leakage and regional recharge to confined aquifers have increased throughout the Virginia Coastal Plain. Although the Fall Zone was possibly a significant source of regional recharge prior to the large withdrawals, greater rates of regional recharge potentially have resulted from large drawdowns near major pumping centers located farther east.

\section{REFERENCES CITED}

Bradbury, K.R., and Muldoon, M.A., 1990, Hydraulic conductivity determinations in unlithified glacial and fluvial materials: Ground Water and Vadose Zone Monitoring, American Society for Testing and Materials Standard Technical Publication 1053, p. 138-151.

Brown, P.M., Miller, J.A., and Swain, F.M., 1972, Structural and stratigraphic framework, and spatial distribution of permeability of the Atlantic Coastal Plain, North Carolina to New York: U.S. Geological Survey Professional Paper 796, 79 p.

Cederstrom, D.J., 1945, Geology and ground-water resources of the Coastal Plain in southeastern Virginia: Virginia Geological Survey, Bulletin 63, 384 p.

Clark, W.B., and Miller, R.L., 1912, The physiography and geology of the Coastal Plain province of Virginia: Virginia Geological Survey, Bulletin 4, p. 13-322.

Cooley, R.L., and Naff, R.L., 1990, Regression modeling of ground-water flow: U.S. Geological Survey Techniques of Water-Resources Investigations, book 3, chap. B4, $232 \mathrm{p}$.

Dischinger, J.B., 1987, Late Mesozoic and Cenozoic stratigraphic framework near Hopewell, Virginia: U.S. Geological Survey Bulletin 1567, 71 p.

Franke, O.L., Reilly, T.E., and Bennett, G.D., 1987, Definition of boundary and initial conditions in the analysis of saturated ground-water flow systems--An introduction: U.S. Geological Survey Techniques of Water-Resources Investigations, book 3, chap. B5, 15 p.

Freeze, R.A., and Cherry, J.A., 1979, Groundwater: Englewood Cliffs, N.J., Prentice-Hall, 604 p.

Haeni, F.P., 1986, The use of electromagnetic methods to delineate vertical and lateral lithologic changes in glacial aquifers: Surface and Borehole Geophysics Methods and Ground Water Instrumentation Conference and Exposition, Denver, Colorado, p. 259-282.

Hamilton, P.A., and Larson, J.D., 1988, Hydrogeology and analysis of the ground-water flow system in the Coastal Plain of southeastern Virginia: U.S. Geological Survey Water-Resources Investigations Report 87-4240, 175 p.

Hammond, E.C., McFarland, E.R., and Focazio, M.J., 1994, Potentiometric surface of the middle Potomac aquifer in Virginia, 1993: U.S. Geological Survey Open-File Report 94-372, $1 \mathrm{p}$. 
Harned, D.A., 1989, The hydrogeologic framework and a reconnaissance of ground-water quality in the Piedmont Province of North Carolina, with a design for future study: U.S. Geological Survey Water-Resources Investigations Report 88-4130, $55 \mathrm{p}$.

Harsh, J.F., and Laczniak, R.J., 1990, Conceptualization and analysis of ground-water flow system in the Coastal Plain of Virginia and adjacent parts of Maryland and North Carolina: U.S. Geological Professional Paper 1404-F, $100 \mathrm{p}$.

Heath, R.C., 1984, Ground-water regions of the United States: U.S. Geological Survey Water-Supply Paper 2242, $78 \mathrm{p}$.

Interpex Limited, 1989, EMIX 34 PLUS Users manual: Golden, Colorado, Interpex Limited.

Johnson, G.H., and Ramsey, K.W., 1987, Geology and geomorphology of the York-James Peninsula, Virginia: Atlantic Coastal Plain Geological Association 1987 Meeting, College of William and Mary, Williamsburg, Virginia, $45 \mathrm{p}$.

Keys, W.S., 1990, Borehole geophysics applied to groundwater investigations: U.S. Geological Survey

Techniques of Water-Resources Investigations, book 2, chap. E2, 150 p.

Laczniak, R.J., and Meng, A.A., III, 1988, Ground-water resources of the York-James Peninsula of Virginia: U.S. Geological Survey Water-Resources Investigations Report 88-4059, 178 p.

McDonald, M.G., and Harbaugh, A.W., 1988, A modular three-dimensional finite-difference ground-water flow model: U.S. Geological Survey Techniques of WaterResources Investigations, book 6, chap. A1, $576 \mathrm{p}$.

McFarland, E.R., 1995, Ground-water flow, geochemistry, and effects of agricultural practices on nitrogen transport at study sites in the Piedmont and Coastal Plain physiographic provinces, Patuxent River Basin, Maryland: U.S. Geological Survey Water-Supply Paper 2449, $72 \mathrm{p}$.

McFarland, E.R., 1997, Hydrogeologic framework, analysis of ground-water flow, and relations to regional flow in the Fall Zone near Richmond, Virginia: U.S. Geological Survey Water-Resources Investigations Report 97-4021, $56 \mathrm{p}$.

McFarland, E.R., 1998, Design, revisions, and considerations for continued use of a ground-waterflow model of the Coastal Plain aquifer system in Virginia: U.S. Geological Survey Water-Resources Investigations Report 98-4085, 49 p.

McFarland, E.R., and Focazio, M.J., 1993, Ground water in Virginia: use during 1990, availability, and resource information needs: U.S. Geological Survey Open-File Report 94-114, 2 p.
Meng, A.A., III, and Harsh, J.F., 1988, Hydrogeologic framework of the Virginia Coastal Plain: U.S. Geological Survey Professional Paper 1404-C, 81 p.

Mixon, R.B., Berquist, C.B., Jr., Newell, W.L., and Johnson G.H., 1989, Geologic map and generalized cross sections of the Coastal Plain and adjacent parts of the Piedmont, Virginia: U.S. Geological Survey Miscellaneous Investigations Series Map I-2033.

Mixon, R.B., Powars, D.S., and Daniels, D.L., 1988, Nature and timing of deformation of Upper Mesozoic and Cenozoic deposits in the inner Atlantic Coastal Plain, Virginia and Maryland: Proceedings of the 1988 U.S. Geological Survey Workshop on the Geology and Geohydrology of the Atlantic Coastal Plain, Reston, Virginia, p. 65-73.

National Weather Service, 1996, Climatological data, Virginia, December 1996, v. 106, no. 12, 26 p.

Onuschak, E., Jr., 1972, February 1972 deep test in Accomack County, Virginia: Virginia Division of Mineral Resources, Virginia Minerals, v. 18, no. 1, p. 1-4.

Pollock, D.W., 1989, Documentation of computer programs to compute and display pathlines using results from the U.S. Geological Survey modular three-dimensional finite-difference ground-water flow model: U.S. Geological Survey Open-File Report 89-381, 188 p.

Powars, D.S., Mixon, R.B., and Bruce, T.S., 1988, Uppermost Mesozoic and Cenozoic geologic cross section, outer Coastal Plain of Virginia: Proceedings of the 1988 U.S. Geological Survey Workshop on the Geology and Geohydrology of the Atlantic Coastal Plain, Reston, Virginia, p. 85-101.

Powars, D.S., and Bruce, T.S., 1999, The effects of the Chesapeake Bay impact crater on the geological framework and correlation of hydrogeologic units of the lower York-James Peninsula, Virginia: U.S. Geological Survey Professional Paper 1612, $82 \mathrm{p}$.

Richardson, C.A., 1980, Ground water in the Piedmont upland of central Maryland: U.S. Geological Survey Water-Resources Investigations Report 80-18, $42 \mathrm{p}$.

Richardson, D.L., 1994, Ground-water discharge from the Coastal Plain of Virginia: U.S. Geological Survey Water-Resources Investigations Report 93-4191, 15 p.

Sanford, Samuel, 1913, The underground water resources of the Coastal Plain province of Virginia: Virginia Geological Survey, Bulletin 5, 361 p.

Virginia Division of Mineral Resources, 1993, Geologic map of Virginia: Virginia Division of Mineral Resources, scale 1:500,000.

Ward, L.W., 1985, Stratigraphy and characteristic mollusks of the Pamunkey Group (lower Tertiary) and the Old Church Formation of the Chesapeake Group--Virginia Coastal Plain: U.S. Geological Survey Professional Paper 1346, $77 \mathrm{p}$. 
Ward, L.W., and Blackwelder, B.W., 1980, Stratigraphic revision of the upper Miocene and lower Pliocene beds of the Chesapeake Group, middle Atlantic Coastal Plain: U.S. Geological Survey Bulletin 1482-D, 71 p.

White, R.K., Hayes, D.C., Eckenwiler, M.R., Belval, D.L., and Herman, P.E., 1997, Water resources data - Virginia - water year 1996, Vol. 1, Surface-water-discharge and surface-water-quality records: U.S. Geological Survey Water Data Report VA-96-1, $557 \mathrm{p}$.

White, R.K., and Powell, E.D., 1997, Water resources data Virginia - water year 1996, Vol. 2, Ground-water-level and ground-water-quality records: U.S. Geological

Survey Water Data Report VA-96-2, 363 p. 


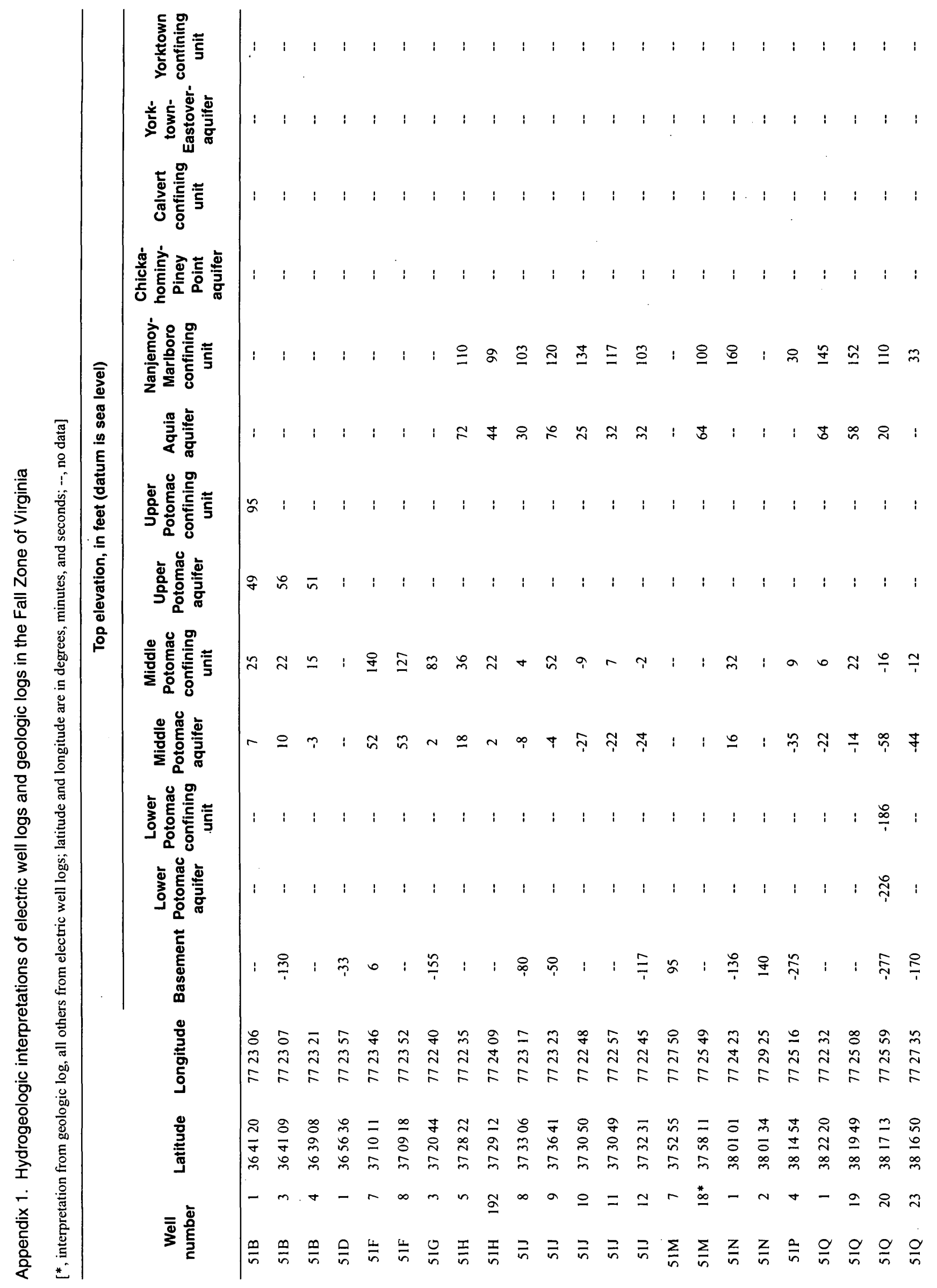

72 Hydrogeologic Framework and Ground-Water Flow in the Fall Zone of Virginia. 


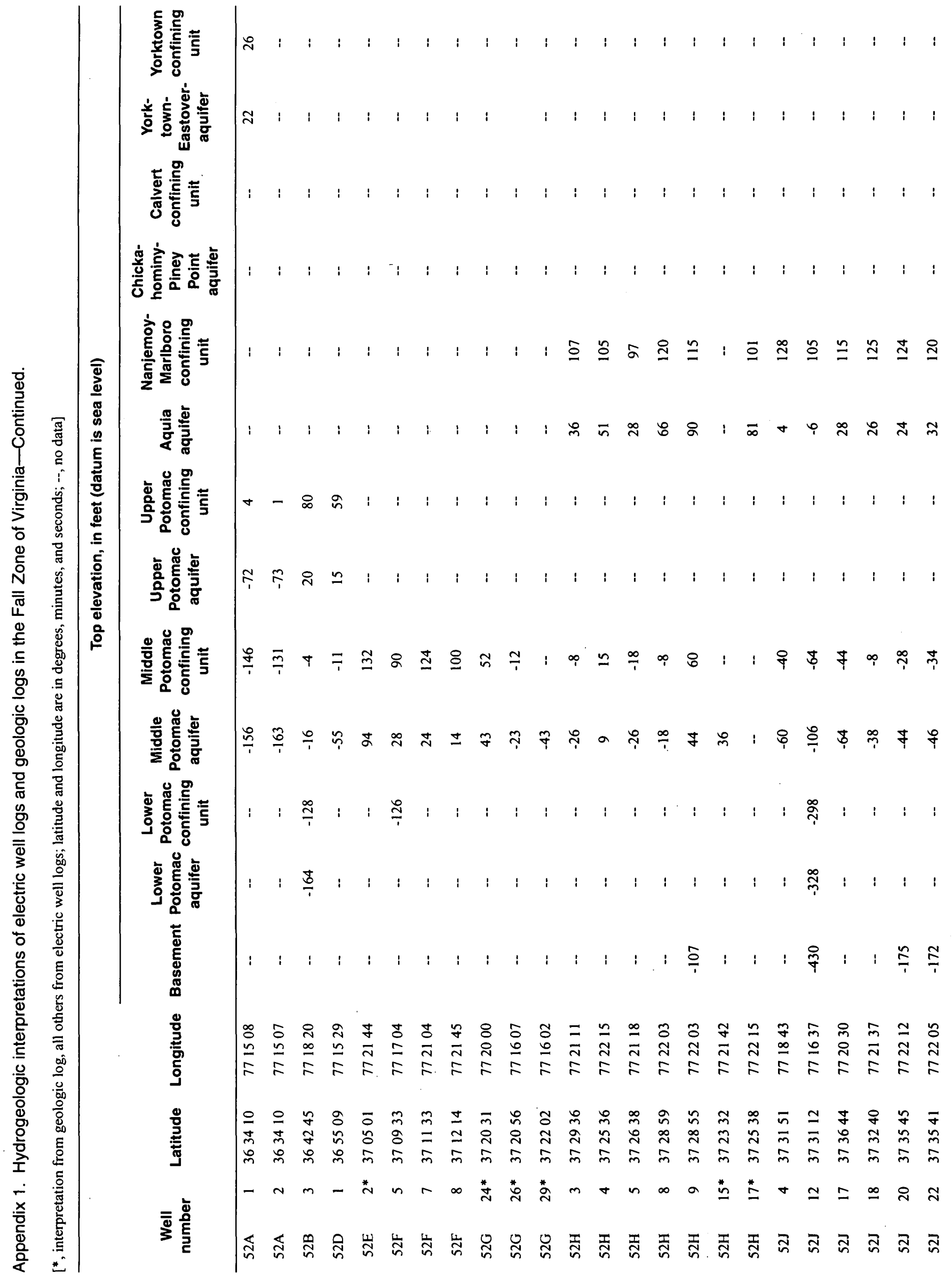




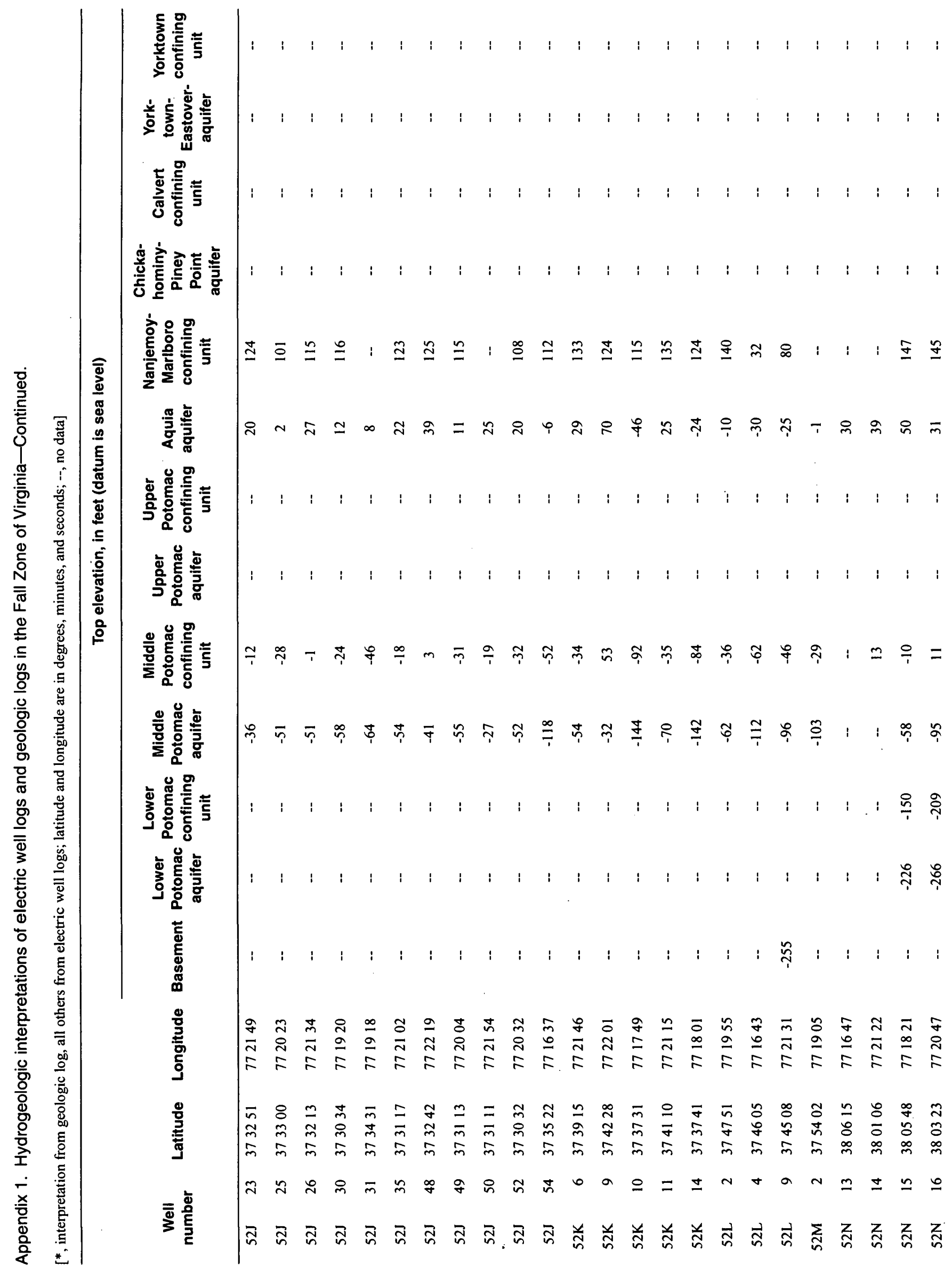

74 Hydrogeologic Framework and Ground-Water Flow in the Fall Zone of Virginia. 


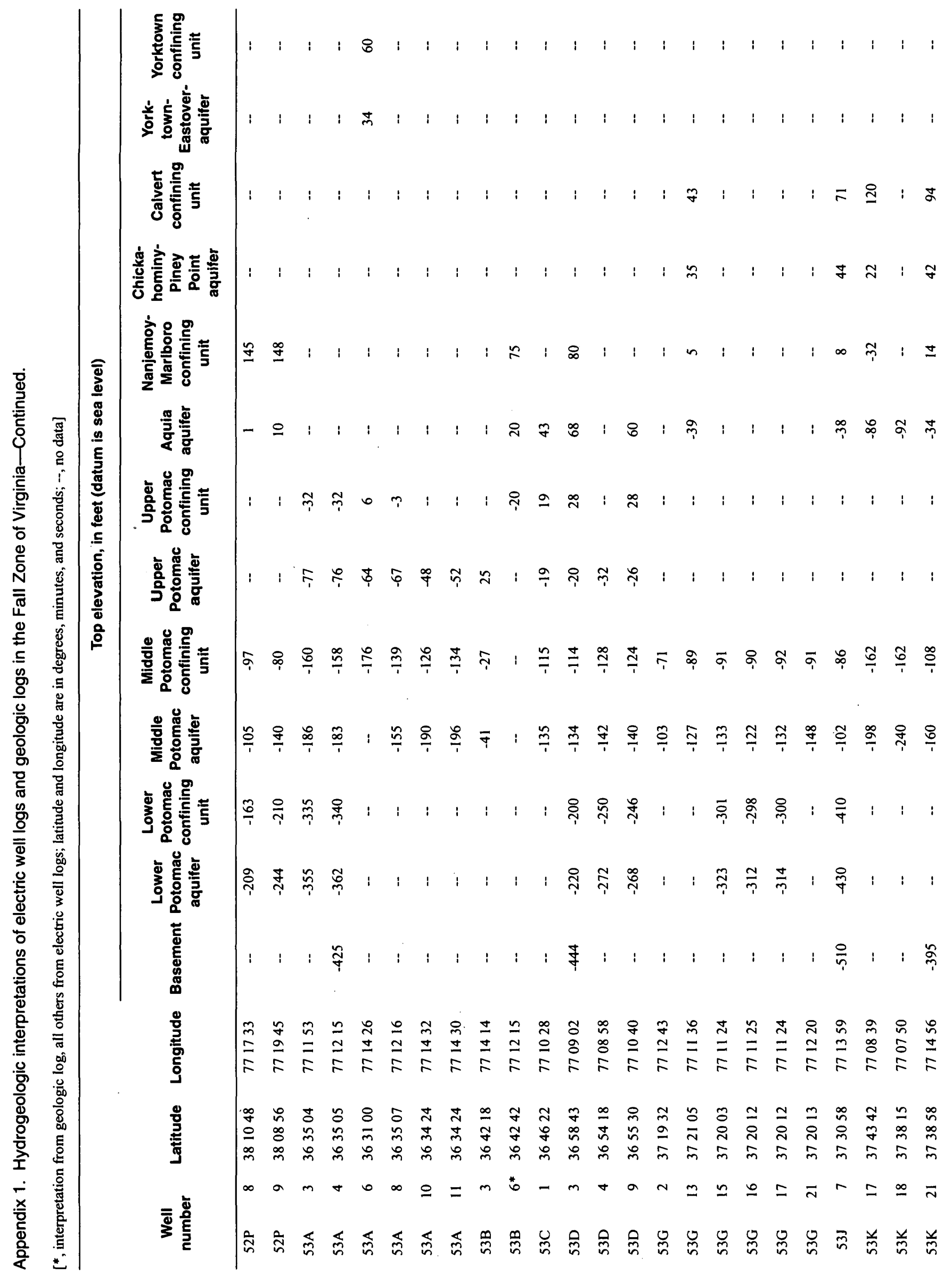




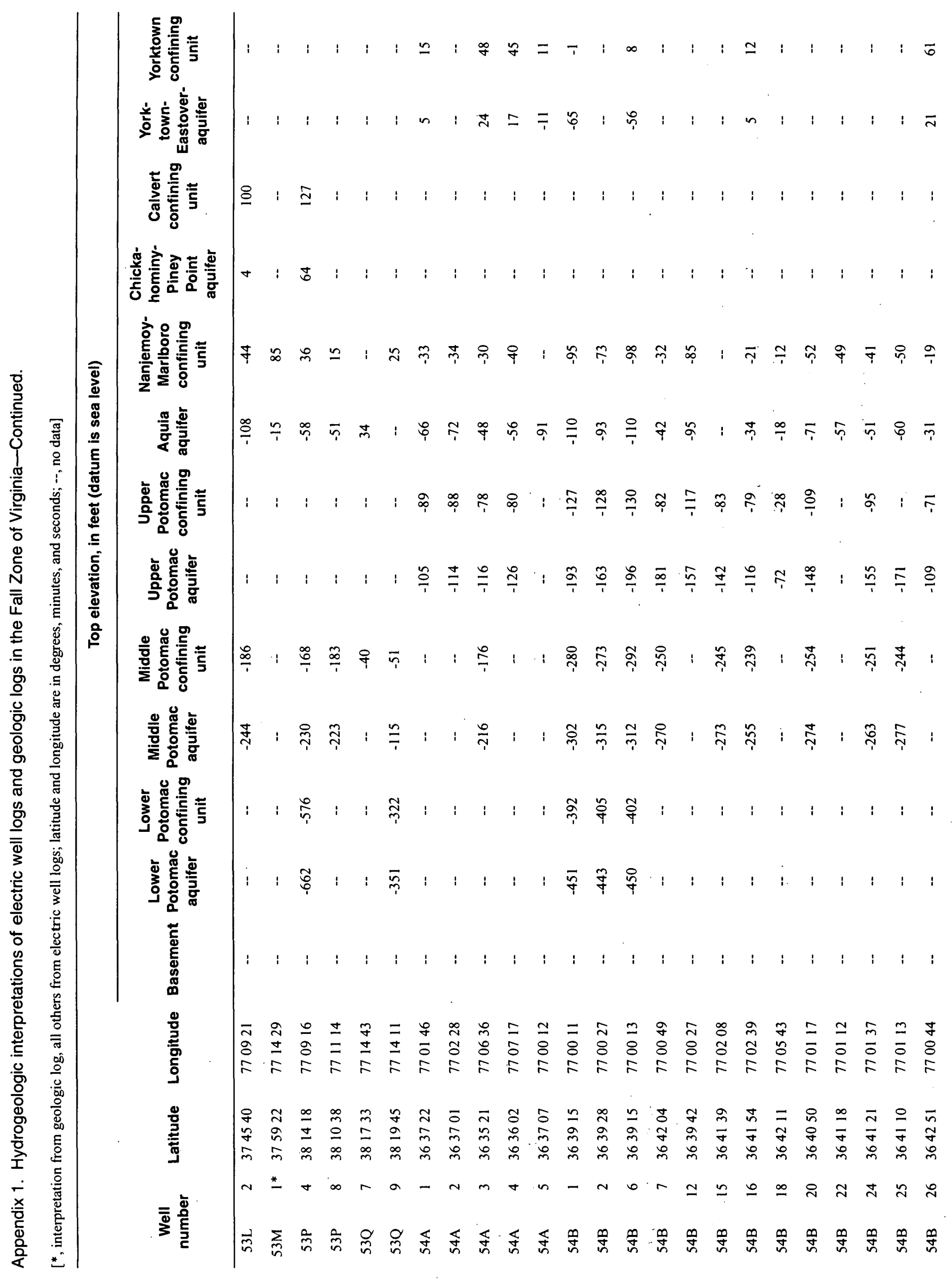




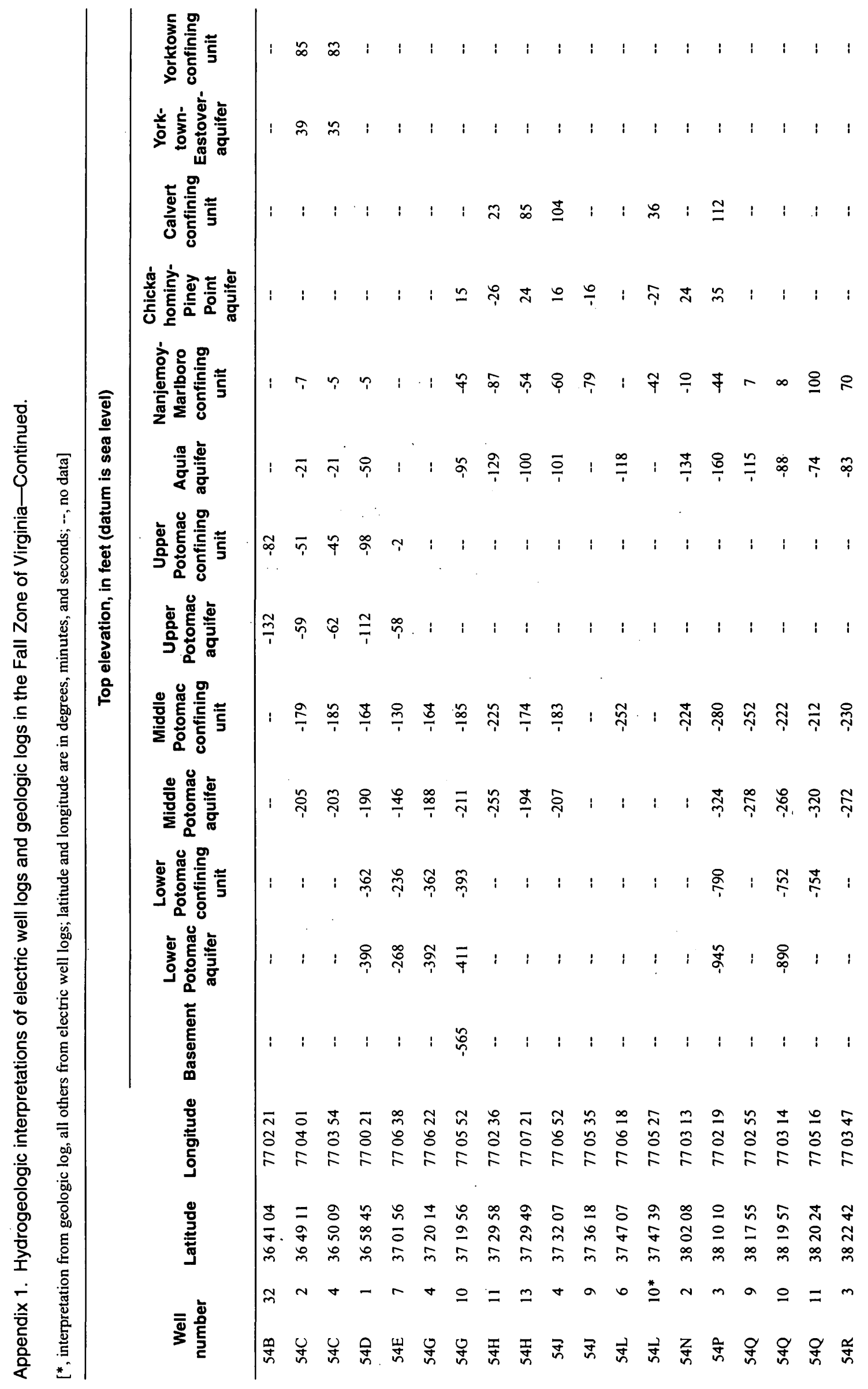


Appendix 2. Geologic logs of observation wells in the Fall Zone, Virginia

[Datum is sea level; *, excerpted from McFarland, 1997; color designations from Munsell classification]

\begin{tabular}{|c|c|}
\hline DEPTH (ft) & GEOLOGIC LOG \\
\hline & FORMATION: alluvium \\
\hline $5-7$ & medium-grained quartz sand, friable, some glauconite, moist, light gray (10 YR 7/4) \\
\hline \multirow[t]{2}{*}{$10-11$} & coarse-grained quartz sand, noncohesive, wet, orange (10YR 6/6) \\
\hline & FORMATION: Nanjemoy \\
\hline $11-12$ & fine-grained sand, silty, gray-green ( $5 \mathrm{GY} 3 / 2)$, very stiff \\
\hline $15-17$ & as $11-12$ above, few shell \\
\hline $20-22$ & as $11-12$ above, few carbonized plant fragments \\
\hline $25-27$ & as $11-12$ above, few mica and foraminifera \\
\hline $30-32$ & as $11-12$ above, few foraminifera \\
\hline $35-37$ & as $11-12$ above, few forams and carbonized plant fragments \\
\hline $40-42$ & as $11-12$ above \\
\hline \multirow[t]{2}{*}{$45-47$} & as $11-12$ above, few glauconite grains \\
\hline & FORMATION: Aquia \\
\hline $50-52$ & $\begin{array}{l}\text { medium-grained quartz sand, pebbly, silty, stiff, some glauconite, few sharks' teeth, iron stone, moist, } \\
\text { calcite cemented sand at } 52 \mathrm{ft}\end{array}$ \\
\hline
\end{tabular}

\begin{tabular}{|c|c|}
\hline DEPTH (ft) & GEOLOGIC LOG \\
\hline & FORMATION: Bacons Castle \\
\hline \multirow[t]{2}{*}{$5-7$} & coarse-to-medium-grained quartz sand, grayish yellow ( $10 \mathrm{YR} 7 / 4,10 \mathrm{YR} 8 / 6,10 \mathrm{YR} 6 / 6$ ), wet \\
\hline & FORMATION: Nanjemoy \\
\hline $10-12$ & silt and fine-grained sand, blue-gray (N4) \\
\hline $15-17$ & as $10-12$ above, slightly more coarse-grained sand \\
\hline $20-21$ & as $10-12$ above \\
\hline $21-22$ & coarse-to-medium grained quartz sand, gray (N5), clayey \\
\hline $25-27$ & clayey silt, green-gray ( $5 G Y 4 / 1)$, stiff \\
\hline $30-32$ & as $25-27$ above \\
\hline $35-37$ & as $25-27$ above, some shell toward bottom, highly fractured, moist \\
\hline \multirow[t]{2}{*}{$40-41$} & as $25-27$ above, more shell, dense, stiff \\
\hline & FORMATION: Potomac \\
\hline $45-46$ & coarse-grained quartz sand, clayey, some iron staining, gamet, light gray (N7) \\
\hline $50-51$ & as $45-46$ above, pebbles up to 1 -inch diameter, toward bottom more fine grained, medium gray ( $5 \mathrm{Y} 6 / 1)$ \\
\hline $55-56$ & as $50-51$ above, wet \\
\hline $60-61$ & as $50-51$ above, more clayey toward bottom \\
\hline $65-66$ & as 50-51 above, noncohesive, light gray (5YR 6/1) \\
\hline
\end{tabular}


Appendix 2. Geologic logs of observation wells in the Fall Zone, Virginia-Continued.

[Datum is sea level; *, excerpted from McFarland, 1997; color designations from Munsell classification]

\begin{tabular}{|c|c|}
\hline \multirow{2}{*}{$\begin{array}{l}\text { WELL: } 52 \mathrm{G} 24^{*} \\
\text { LAND-SURFACE ELEVATION: } 70 \mathrm{ft}\end{array}$} & \multirow{2}{*}{$\begin{array}{l}\text { LATITUDE: } 37^{\circ} 20^{\prime} 31^{\prime \prime} \\
\text { LONGITUDE: } 77^{\circ} 20^{\prime} 00^{\prime \prime}\end{array}$} \\
\hline & \\
\hline DEPTH (ft) & GEOLOGIC LOG \\
\hline & FORMATION: Yorktown \\
\hline $3-5$ & clayey coarse-grained quartz sand, orange (10 YR 6/6) \\
\hline \multirow[t]{2}{*}{18} & as 3-5 depth above \\
\hline & FORMATION: Aquia \\
\hline \multirow[t]{2}{*}{$18-20$} & clayey silt and fine-grained sand, dark blue ( $5 \mathrm{GY} 2 / 1)$, micaceous, glauconitic \\
\hline & FORMATION: Potomac \\
\hline $28-30$ & \multirow{3}{*}{$\begin{array}{l}\text { coarse-grained quartz sand, pebbly, clayey, gray }(5 \text { Y } 6 / 1) \\
\text { sandy clay, very tough and dense, dark gray }(5 G Y 4 / 1) \text {, coarse sand grains, pebbly toward top, fracturesin } \\
\text { clay with light gray linings } \\
\text { coarse- to very coarse-grained sand and gravel, clayey, vericolored (top } 5 \text { YR } 6 / 4 \text {, bottom N 9) }\end{array}$} \\
\hline $68-70$ & \\
\hline $73-75$ & \\
\hline
\end{tabular}

WELL: $52 \mathrm{G} 26^{*}$

LATITUDE: $37^{\circ} 20^{\prime} 56^{\prime \prime}$

LAND-SURFACE ELEVATION: $5.00 \mathrm{ft}$

LONGITUDE: $77^{\circ} 16^{\prime} 07^{\prime \prime}$

\begin{tabular}{|c|c|}
\hline DEPTH (ft) & GEOLOGIC LOG \\
\hline & FORMATION: alluvium \\
\hline \multirow{3}{*}{$\begin{array}{c}0-5 \\
6-16\end{array}$} & silty sand \\
\hline & . \\
\hline & FORMATION: Aquia \\
\hline \multirow[t]{2}{*}{$17-27$} & silt, sandy, clayey, very micaceous, some shells and forams, burrowed \\
\hline & FORMATION: Potomac \\
\hline $28-47$ & sand, milley matrix, some garnets \\
\hline $48-56$ & clay, green gray \\
\hline 57 & sand \\
\hline $58-59$ & clay \\
\hline $60-72$ & sand \\
\hline
\end{tabular}

\begin{tabular}{|c|c|}
\hline DEPTH (ft) & GEOLOGIC LOG \\
\hline & FORMATION: alluvium \\
\hline $0-2$ & soil, brown \\
\hline $3-4$ & medium-grained quartz sand, clayey, dense, brown \\
\hline $5-9$ & sand, gray brown, mottled, soupy \\
\hline $10-19$ & gravel and coarse sand, orange, soupy \\
\hline $20-45$ & coarse pebbly sand, soupy \\
\hline \multirow[t]{2}{*}{46} & coarse sand, mint green, soupy \\
\hline & FORMATION: Potomac \\
\hline $47-53$ & coarse sand, pebbly, clayey with clay clasts, indurated, pinkish buff \\
\hline $54-55$ & clay, pebbly, pinkish buff \\
\hline $56-57$ & sand, pinkish buff \\
\hline $58-59$ & medium-grained sand, clayey, off-white \\
\hline $60-65$ & pebbly sand, pinkish buff \\
\hline $66-97$ & medium-grained sand, silty, stiff, orange mottles, few gray-green clay clasts increase toward base \\
\hline
\end{tabular}


Appendix 2. Geologic logs of observation wells in the Fall Zone, Virginia-Continued.

[Datum is sea level; *, excerpted from McFarland, 1997; color designations from Munsell classification]

\begin{tabular}{|c|c|}
\hline DEPTH (ft) & GEOLOGIC LOG \\
\hline \multicolumn{2}{|r|}{ FORMATION: Windsor } \\
\hline $4-5.5$ & clay, silty, orange (10YR 6/6), dry, few gray mottles, fine-grained sand and mica \\
\hline $9-10.5$ & fine-grained sand, orange ( $10 \mathrm{YR} 6 / 6)$, dry, low cohesion, few mica and carbonized plant fragments \\
\hline $14-15.5$ & as from $9-10.5$ above, cohesionless \\
\hline 19-20.5 & $\begin{array}{l}\text { fine-grained sand, orange (10YR 6/6) and gray (5Y 8/1), clayey, some mottles, mica, and carbon staining, } \\
\text { dry }\end{array}$ \\
\hline $24-25.5$ & as from 19-20.5 above, few half-inch pebbles \\
\hline $29-30.5$ & $\begin{array}{l}\text { as from } 24-25.5 \text { above, dense lense of inch-diameter gravel, second dense lense of fine-grained sand, } \\
\text { orange, iron stained }\end{array}$ \\
\hline $34-35.5$ & as from $29-30.5$ above, more gravel, some iron-oxide coatings and stains \\
\hline $39-40.5$ & as from $34-35.5$ above, medium-grained sand, $\tan (10 \mathrm{YR} 7 / 4)$ \\
\hline $44-45.5$ & gravel and medium-grained sand, wet, iron stained, some clay, heavy, plastic, orange (10YR 6/6) \\
\hline \multicolumn{2}{|r|}{ FORMATION: Potomac } \\
\hline $49-50.5$ & medium-grained sand, wet, some clay, orange (10YR 6/6) and light gray (10YR 8/2) \\
\hline $54-55.5$ & $\begin{array}{l}\text { medium-grained sand, moist, clayey, light gray (N7), some one-half-inch pebbles and carbonized plant } \\
\text { fragments, few mica }\end{array}$ \\
\hline $59-60.5$ & $\begin{array}{l}\text { as from } 54-55.5 \text { above, coarse-grained sand, more pebbles, } 1 \text {-inch-diameter clay clast, light gray ( } 5 \text { YR } 8 / 1) \text {, } \\
\text { clay matrix, gray (N6) }\end{array}$ \\
\hline $64-65.5$ & $\begin{array}{l}\text { near top medium-grained sand, clayey, } \tan (10 \mathrm{YR} 7 / 4) \text {, grades downward to coarse-grained sand and gravel, } \\
\text { clayey, gray (N5), moist }\end{array}$ \\
\hline $69-70.5$ & medium to coarse-grained sand, clayey, $\tan (10 \mathrm{YR} 7 / 4)$, some pebbles, moist \\
\hline $74-75.5$ & medium to coarse-grained sand, light gray (N7), some clay \\
\hline $79-80.5$ & $\begin{array}{l}\text { coarse-grained sand, dark gray (N3), some clay, few pebbles and greater than 1-inch-long clay clasts, light } \\
\text { gray (N7 and } 5 \text { YR 8/1) }\end{array}$ \\
\hline
\end{tabular}

\begin{tabular}{|c|c|}
\hline DEPTH (ft) & GEOLOGIC LOG \\
\hline & FORMATION: Bacons Castle \\
\hline 4-5.5 & clay, silty, pebbly, red (10R 4/6), some fine-grained sand, pebbles up to $1 \mathrm{inch}$, dry and stiff \\
\hline $9-10.5$ & medium-grained sand, silty, red (10R 4/6), some pebbles up to one-half-inch, low cohesion, moist \\
\hline 14-15.5 & top half as $9-10.5$ above, bottom half coarse-grained sand, orange ( 10 YR $6 / 6$ ), pebbles to 1 inch, friable \\
\hline 19-20.5 & coarse-grained sand, pebbly, orange (10YR 6/6), moist, friable, low recovery because of spoon refusal \\
\hline $24-25.5$ & medium to coarse-grained sand, pebbly, orange (10YR 6/6), some clay, friable, very moist \\
\hline \multirow[t]{2}{*}{$29-30.5$} & as 24-25.5 above, wet, cohesionless \\
\hline & FORMATION: Calvert \\
\hline $34-35.5$ & very fine-grained sand, silty, orange (10YR $6 / 6)$ and gray (10Y $8 / 1)$, mottled, moist \\
\hline $39-40.5$ & as $34-35.5$ above, dark gray ( $5 \mathrm{GY} 4 / 1)$ \\
\hline $44-45.5$ & as $39-40.5$ above, plastic \\
\hline \multirow[t]{2}{*}{$49-50.5$} & clay, silty, gray green ( $5 G Y 6 / 1$ ), some mica, few glauconite, stiff \\
\hline & FORMATION: Potomac \\
\hline $54-55.5$ & coarse-grained sand, pebbly, clayey, dark gray ( $5 \mathrm{GY} 4 / 1$ ), pebbles to one-half-inch, wet, low cohesion \\
\hline $59-60.5$ & medium-grained sand, light gray (N7), moist, cohesive, micaceous, some carbonized material, clayey \\
\hline $64-65.5$ & $\begin{array}{l}\text { medium to coarse-grained sand, light gray (N7), moist, pebbly, pebbles to one-half-inch, some clay and } \\
\text { mica }\end{array}$ \\
\hline $69-70.5$ & as $64-65.5$ above, wet, cohesionless, less clay, no mica \\
\hline 74-75.5 & as $69-70.5$ above, slightly more clayey and cohesive \\
\hline $79-80.5$ & as $74-75.5$ above, coarse-grained sand, cohesionless \\
\hline
\end{tabular}


Appendix 2. Geologic logs of observation wells in the Fall Zone, Virginia-Continued.

[Datum is sea level; *, excerpted from McFarland, 1997; color designations from Munsell classification]

\begin{tabular}{|c|c|}
\hline DEPTH (ft) & GEOLOGIC LOG \\
\hline & FORMATION: Bacons Castle \\
\hline $5-7$ & $\begin{array}{l}\text { fine-to-medium grained quartz sand, clayey, gray ( } 5 Y R 8 / 1) \text {, orange and red mottles, moist, few heavy } \\
\text { minerals }\end{array}$ \\
\hline $10-12$ & medium-grained sand, gray $(5 Y 8 / 1)$, wet, slightly clayey, few heavy minerals \\
\hline \multirow[t]{2}{*}{$15-17$} & as $10-12$ above, some orange mottling (5YR $5 / 6)$ \\
\hline & FORMATION: Eastover \\
\hline $20-22$ & silt, dark green-gray $(5 \mathrm{G} 4 / 1)$, moist \\
\hline $25-27$ & as $20-22$ above, dense, some fine-grained sand, some shell toward bottom \\
\hline $30-32$ & as $25-27$ above, very dense, dry, scattered shell \\
\hline $35-37$ & as $30-32$ above, $5 G Y 5 / 1$, some clay clasts ( 5 Y $3 / 2)$ \\
\hline $40-42$ & as $35-37$ above, some intact turritella 0.5 -inch length \\
\hline $45-47$ & as $40-42$ above \\
\hline $50-52$ & as $40-42$ above \\
\hline $55-57$ & as 40-42 above, some isognomon "mother-of-pearl" fragments in clay borrows \\
\hline $60-62$ & as $40-42$ above \\
\hline $65-67$ & as $40-42$ above, very shelly, glauconitic \\
\hline $70-72$ & medium-grained sand, silty, very shelly, isognomon, glauconitic, $5 \mathrm{GY} 4 / 1$, moist \\
\hline $75-77$ & fine-to-medium grained sand, shelly, glauconitic, $5 \mathrm{GY} 6 / 1$, wet \\
\hline $80-82$ & cemented shells \\
\hline $85-87$ & medium-grained sand, glauconitic, shelly, gray (10GY 5/2), cemented shells toward top, moist \\
\hline \multirow[t]{2}{*}{$90-92$} & as $85-87$ above, more shelly toward bottom \\
\hline & FORMATION: Saint Marys (?) \\
\hline \multirow[t]{2}{*}{$95-97$} & clay, plastic, dark gray (5GY 4/1), pyrite, forams, dry, firm \\
\hline & FORMATION: Aquia \\
\hline $100-102$ & medium-grained sand, chlorite stained, glauconitic, shell clasts 1.5-inch diameter \\
\hline $105-107$ & as $100-102$ above, clayey, firm, moist, green-gray ( $5 \mathrm{G} 4 / 1)$ \\
\hline \multirow[t]{2}{*}{$110-112$} & as $105-107$ above, wet, noncohesive \\
\hline & FORMATION: “Red Beds” \\
\hline $115-117$ & clay, dense, red-gray (5YR 4/1) with orange and yellow \\
\hline
\end{tabular}


Appendix 2. Geologic logs of observation wells in the Fall Zone, Virginia-Continued.

[Datum is sea level; *, excerpted from McFarland, 1997; color designations from Munsell classification]

LAND-SURFACE ELEVATION: $89 \mathrm{ft}$

\begin{tabular}{|c|c|}
\hline DEPTH (ft) & GEOLOGIC LOG \\
\hline & FORMATION: alluvium \\
\hline \multirow[t]{2}{*}{$5-7$} & $\begin{array}{l}\text { coarse-grained quartz sand, pebbly, slightly clayey, yellow-orange (10YR 7/4, 10YR 6/6), some heavy } \\
\text { minerals, soft, wet }\end{array}$ \\
\hline & FORMATION: Calvert \\
\hline $10-12$ & fine-grained quarts sand, silty, well sorted, glauconitic, green-gray ( $5 \mathrm{GY} 3 / 2)$, moist \\
\hline $15-17$ & as $10-12$ above, lighter ( $10 \mathrm{Y} 4 / 2)$, scattered phosphate \\
\hline $20-22$ & $\begin{array}{l}\text { fine-grained sand, silty, stiff, glauconite in sandy lenses, some phosphate grains, scattered forams, } \\
\text { gray-green }(5 \mathrm{GY} 5 / 2)\end{array}$ \\
\hline \multirow[t]{2}{*}{$25-27$} & medium-to-coarse sand, silty, phosphate grains and pebbles, dark gray-green ( $5 G Y 3 / 2)$, stiff \\
\hline & FORMATION: Nanjemoy \\
\hline $30-32$ & $\begin{array}{l}\text { fine-grained sand, silty, micaceous, slightly glauconitic, scattered shell and carbonized wood fragments, } \\
\text { dark gray }(5 \mathrm{GY} 4 / 1)\end{array}$ \\
\hline $35-37$ & as $30-32$ above, more glauconitic and shelly, less micaceous, darker $(5 G 4 / 1)$ \\
\hline $40-42$ & as $35-37$ above, more glauconitic and shelly, less micaceous, darker (5G $3 / 2)$ \\
\hline $45-47$ & fine-grained sand, silty, micaceous, slightly glauconitic, very shelly toward bottom, green-gray ( $5 G Y 3 / 2)$ \\
\hline $50-52$ & as $45-47$ above, variably shelly and glauconitic \\
\hline $55-57$ & as $45-47$ above, slightly shelly, stiff, clayey \\
\hline $60-62$ & as $45-47$ above, more shelly, less glauconitic \\
\hline $65-67$ & as $45-47$ above \\
\hline \multirow[t]{2}{*}{$70-72$} & as $45-47$ above, slightly shelly and glauconitic \\
\hline & FORMATION: Marlboro Clay(?) \\
\hline \multirow[t]{2}{*}{$85-88$} & hard drilling \\
\hline & FORMATION: Aquia \\
\hline \multirow[t]{2}{*}{$90-92$} & fine-grained sand, silty, moderately glauconitic and micaceous and shelly, dark gray ( $5 \mathrm{GY} 4 / 1$ ) \\
\hline & FORMATION: Potomac \\
\hline $105-110$ & coarse-grained quartz sand, pebbly \\
\hline
\end{tabular}


Appendix 2. Geologic logs of observation wells in the Fall Zone, Virginia-Continued.

[Datum is sea level; *, excerpted from McFarland, 1997; color designations from Munsell classification]

\begin{tabular}{|c|c|}
\hline DEPTH (ft) & GEOLOGIC LOG \\
\hline & FORMATION: Shirley \\
\hline $5-7$ & medium-to-coarse-grained quartz sand, noncohesive, dry, yellow (10YR 6/6), few heavy minerals \\
\hline $10-12$ & as 5-7 above, more coarse-grained, pebbles up to 0.5 -inch diameter, wet \\
\hline \multirow[t]{2}{*}{$15-17$} & as $10-12$ above, yellow-gray (10YR $7 / 4)$, few clay balls \\
\hline & FORMATION: Calvert \\
\hline $20-22$ & $\begin{array}{l}\text { fine-grained sand, silty, gray-green (upper } 5 G Y 5 / 2 \text {, lower } 5 G Y 3 / 2 \text { ), firm, dry, phosphate fragments, } \\
\text { diatoms }\end{array}$ \\
\hline $25-27$ & as $20-22$ above, more firm \\
\hline $30-32$ & clayey silt, forams, gray-green ( $5 \mathrm{GY} 3 / 2,5 \mathrm{GY} 5 / 2)$ \\
\hline $35-37$ & fine-grained sand, silty, few phosphate fragments and forams, green-gray (5Y 3/2) \\
\hline $40-42$ & as $35-37$ above \\
\hline $45-47$ & as $35-37$ above, $10 \mathrm{Y} 4 / 2$, moist, less firm, slightly more coarse grained \\
\hline $50-52$ & as $35-37$ above \\
\hline $55-57$ & silt, sandy glauconitic interbeds, olive (10Y 4/2), few phosphate fragments \\
\hline $60-62$ & FORMATION: Old Church \\
\hline $65-67$ & fine-to-medium grained sand, quartz and glauconite, silty, slightly shelly, green-black (5GY 2/1) \\
\hline $70-72$ & as $65-67$ above, pebbly, less silty, some shell grains, soft, moist, lighter (5GY 4/1) \\
\hline $75-77$ & as 65-67 above, slightly less glauconite, lighter, less moist \\
\hline $80-82$ & as $65-67$ above, more shell grains, bivalves up to 1 -inch width, moist \\
\hline $85-87$ & $\begin{array}{l}\text { as } 65-67 \text { above, some shell fragments, less glauconite, indurated gravel up to } 1 \text {-inch diameter, less green } \\
(5 Y 4 / 1)\end{array}$ \\
\hline $90-92$ & $\begin{array}{l}\text { fine-to-medium grained sand, quartz, slightly glauconitic, some shell and mica, indurated gravel up to } \\
1 \text {-inch diameter, dark gray }(5 \mathrm{Y} 3 / 2)\end{array}$ \\
\hline \multirow[t]{2}{*}{$95-97$} & fine sand, quartz, very slightly glauconitic, dark gray ( $5 Y 3 / 2)$, some mica, slightly shelly, moist \\
\hline & FORMATION: Nanjemoy \\
\hline $100-102$ & $\begin{array}{l}\text { fine sand, quartz, very slightly glauconitic, some pebbles and mica, few shells and carbonized wood } \\
\text { fragments, } 5 \mathrm{G} 3 / 2\end{array}$ \\
\hline
\end{tabular}


